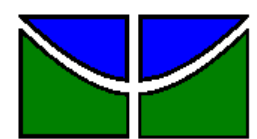

Universidade de Brasília

Faculdade de Economia, Administração e Contabilidade

Programa de Pós-Graduação em Economia

Mestrado Profissional em Economia

MARISTELA ABAD

Extensão Universitária e sua Eficácia: estudo de caso do UnB Idiomas

Brasília, DF

2015 
MARISTELA ABAD

Extensão Universitária e sua eficácia: estudo de caso do UnB Idiomas

Dissertação de Mestrado apresentada à Faculdade de Economia, Administração e Contabilidade da Universidade de Brasília, como requisito parcial para a obtenção do título de Mestre em Economia.

Orientadora: Profa. Dra. Denise Imbroisi

Brasília, DF

2015 


\section{Extensão Universitária e sua eficácia: estudo de caso do UnB Idiomas}

Dissertação aprovada como requisito para obtenção do título de Mestre em Economia, Gestão Econômica de Finanças Públicas. Curso oferecido pelo Programa de PósGraduação em Economia - Departamento de Economia da Universidade de Brasília, por intermédio da Coordenadoria de Capacitação (PROCAP), do Decanato de Gestão de Pessoas (DPG). Comissão examinadora formada por:

Profa. Dra. Denise Imbroisi

Departamento de Economia - UnB

Prof. Dr. Pedro Henrique Zuchi Conceição

Departamento de Economia - UnB

Prof. Dr. Antônio Nascimento Junior

Departamento de Administração - UnB

Brasília, 21 de agosto de 2015. 


\section{AGRADECIMENTOS}

À minha querida Universidade de Brasília, que sempre me ofereceu tantas oportunidades, meu agradecimento eterno por pertencer à sua comunidade.

À minha Orientadora, Professora Denise Imbroisi, eu devo muito: ensinamentos, paciência e, sobretudo, o exemplo de seu comportamento humano e profissional.

Sou muita grata à Professora Milene Takasago, Coordenadora do Programa de Pós-graduação, pela confiança em relação ao meu desempenho.

Meu agradecimento especial à amiga e colega de trabalho Miriam, pela enorme ajuda e apoio na elaboração desta dissertação.

Agradeço a todos os colegas do UnBIdiomas, LET e IL, que diretamente ou indiretamente, me auxiliaram na elaboração desta dissertação. Espero ter correspondido à confiança em mim depositada.

Aos colegas do Mestrado pela convivência e compartilhamento de experiências. Um obrigada muito especial ao colega Dinuari (In memoriam), sentiremos a sua falta.

À minha filha amada, o meu muito obrigada pelo seu enorme carinho, ao meu esposo agradeço pelo amor e apoio durante este momento da minha vida.

Agradeço a minha família, em especial ao meu pai e minha mãe, que soube compreender os momentos de ausência e desatenção, torcendo para que esta dissertação fosse logo concluída. 
"O Sucesso nasce do querer, da determinação e persistência em se chegar a um objetivo. Mesmo não atingindo o alvo, quem busca e vence obstáculos no mínimo fará coisas admiráveis”.

José de Alencar 


\section{RESUMO}

A avaliação das ações extensionistas é um importante instrumento para a validação ou não de seus processos e resultados em relação aos objetivos das políticas instituídas. Ademais, a avaliação pode ser um instrumento fundamental para se alcançar melhores resultados e proporcionar uma melhor utilização e controle dos recursos aplicados nos Programas e Projetos extensionistas, como também fornecer aos gestores dados importantes para o desenho de políticas mais consistentes. Esta pesquisa buscou avaliar a eficácia da Extensão Universitária à luz das normas extensionistas praticadas em uma universidade federal e das Políticas de Extensão hoje praticadas no Brasil, tendo como objeto da pesquisa o UnB Idiomas, Programa de Extensão da Universidade de Brasília. A fim de captar as informações necessárias para a pesquisa foram analisados documentos do Programa e levantados dados, obtidos no Sistema de Gestão Integrada do UnB Idiomas. A partir da análise dos dados, constatou-se a eficácia do Programa na dimensão do desenvolvimento de seus conhecimentos e propostas de solução para o atendimento das necessidade e expectativas da sociedade, conforme preconizado nas políticas de extensão da UnB e do Brasil. Foram identificados, ainda, alguns desafios que se apresentam para o Programa tais como o de aumentar as parcerias para a melhoria da articulação das atividades extensionistas com o ensino e a pós-graduação, e o de se investir no processo avaliativo do Programa como um todo, o que oferece contribuições relevantes para a construção da Política de avaliação das ações extensionistas na UnB.

Palavras Chaves: Eficácia da Extensão Universitária, Avaliação de Políticas Extensionistas. 


\begin{abstract}
The evaluation of the actions of extension in the scope of universities is an important tool to verify the validity of its processes and results in relation to the objectives of the policies established. Moreover, evaluation can be a fundamental tool to reach better results and to provide better use and control of the resources applied to the programs and projects of extension, as well as to provide the managers important data to draw policies that are more consistent. This research focus on the evaluation of the efficacy of university's extension in light of the rules practiced in the federal universities in Brazil, using as object of this research UnB Idiomas, an extension program of the University of Brasilia. In order to get the necessary information to the research, documents were analised and data was collected through the Integrated Management System of UnB Idiomas. From the analysis of the data, the efficacy of the program was certified as it cooperates through the development of knowledge and solutions proposed to attend the necessities and expectations of the society, as it is advocated in the extension policies at $\mathrm{UnB}$ as well as the extension policies in the universities of Brazil. Yet, some challenges to the program were identified such as the necessity to increase the partnerships in order to improve the articulation of extension activities with graduation and post-graduation programs, and the investment in the evaluation process as a whole, which will offer a relevant contribution to the construction of the extension evaluation policy at UnB.
\end{abstract}

Key words: efficacy of university extension, evaluation of the extension policies. 


\section{LISTA DE FIGURAS}

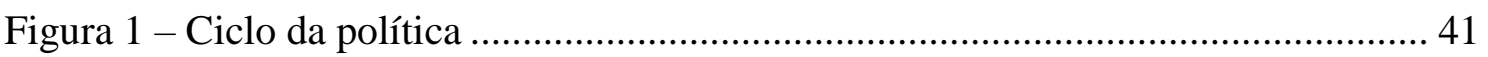

Figura 2: Organização do Programa Permanente de Extensão UnB Idiomas ................. 63

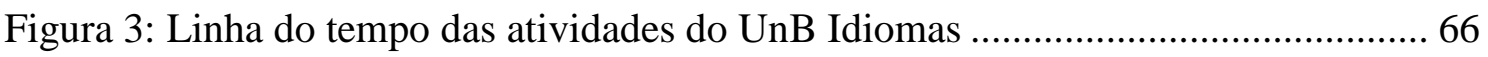

\section{LISTA DE GRÁFICOS}

Gráfico 1 - Indicadores de qualidade de avaliação geral dos Cursos $-2014^{(2)}$............. 73

Gráfico 2 - Indicadores de qualidade dos cursos por idioma - 2014 ............................ 74

Gráfico 3 - Evolução do número de matrículas em Cursos abertos sequenciais - 2009 a 2014.

Gráfico 4 - Distribuição da demanda para o público externo e interno matriculados em

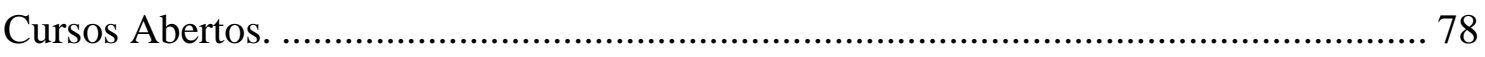

Gráfico 5 - Indicadores de qualidade de avaliação geral dos cursos - 2014 . ................ 78

Gráfico 6 - Indicadores de qualidade dos cursos por idioma - 2014 …........................ 79

Gráfico 7 - Evolução do número de matrículas em cursos para a 3 $3^{\text {a }}$ Idade - 2010 a 2014.

Gráfico 8 - Indicadores de qualidade de avaliação geral dos cursos - 2014 . ................ 81

Gráfico 9 - Indicadores de qualidade dos cursos por idioma - 2014 ............................. 81

Gráfico 10 - Relação de bolsas ofertadas e ocupadas - 2009 a 2014 ........................... 87

Gráfico 11 - Percurso de um grupo de alunos do curso de inglês. ............................... 88

Gráfico 12 - Evolução do número de alunos em cursos corporativos - 2009 a 2014.... 92

Gráfico 13 - Indicadores de qualidade de avaliação geral - 2014 ................................ 93

Gráfico 14 - Indicadores de qualidade de cursos por idioma - 2014........................... 93

Gráfico 15 - Receita Bruta arrecadada e corrigida pelo IPCA ${ }^{1}$ - 2009 a 2014 ............. 94

Gráfico 16 - Valores repassados ao LET e corrigidos pelo IPCA ${ }^{1}-2009$ a 2014....... 95

Gráfico 17 - Valores totais repassados à FUB, IL e LET - 2009 a 2014 . ..................... 96

\section{LISTA DE QUADROS}

Quadro 1 - Normas relacionadas à Extensão Universitária na UnB............................. 31

Quadro 2 - Caracterização de tipos de Políticas Públicas por critérios de abrangência. 47

Quadro 3 - Dimensões para avaliação de políticas....................................................... 52

Quadro 4 - Diferenças entre os tipos de avaliação de políticas públicas segundo critérios de aplicação. 
Quadro 5 - Critérios de avaliação aplicados às políticas públicas.................................. 55

Quadro 6 - Atores participantes das atividades do UnB Idiomas e sua atuação............ 67

Quadro 7 - Objetivos dos Projetos extensionistas do UnB Idiomas. .............................. 68

Quadro 8 - Organização dos cursos constantes do Projeto............................................. 72

Quadro 9 - Organização dos cursos sequenciais de idiomas do Projeto........................ 75

Quadro 10 - Organização dos cursos de idiomas para a 3 ${ }^{\mathrm{a}}$. Idade.................................. 79

Quadro 11 - Organização dos cursos com finalidade específica.................................... 82

Quadro 12 - Organização dos Cursos Preparatórios para Exames de Proficiência........ 83

Quadro 13 - Organização dos Cursos Temáticos............................................................ 83

Quadro 14 - Objetivo e estrutura dos Cursos Corporativos de Idiomas ......................... 90

Quadro 15 - Contratos em execução no âmbito do Projeto............................................. 91

\section{LISTA DE TABELAS}

Tabela 1 - Descrição da escala de avaliação para o ISA............................................... 71

Tabela 2 - Estudantes matriculados em disciplinas de Estágio Supervisionado - 2009 a 2014.

Tabela 3 - Número de matrículas do Projeto de estágio supervisionado - 2009 a 2014.73

Tabela 4 - Evolução do número de alunos matriculados por idioma nos Cursos abertos -

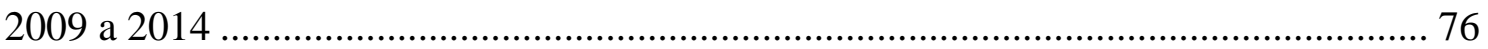

Tabela 5 - Distribuição do número de matrículas por público participante. ................... 77

Tabela 6 - Evolução do número de matrículas dos cursos para a $3^{\circ}$ Idade - 2010 a 2014

Tabela 7 - Evolução de matrículas campus Asa Norte - 2009 a 2014 .......................... 85

Tabela 8 - Expansão do Projeto de Cursos Abertos Sequenciais de Idiomas para outros

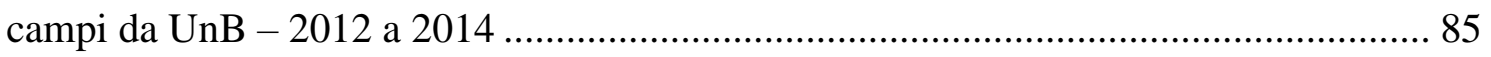

Tabela 9 - Evolução do número de matriculas no SCS - 2012 a 2014 .......................... 86

Tabela 10 - Oferta de bolsas ofertadas e ocupadas nos Cursos Abertos Sequenciais - 2009 a 2014

Tabela 11 - Variação dos valores nominais de taxas de matrículas dos Cursos Abertos Sequenciais de Idiomas.

Tabela 12 - Valores corrigidos conforme variação do IPCA, considerando pagamento da Taxa única no mês de janeiro de cada ano - atualizado até janeiro/2015. 89 
Tabela 13 - Número de alunos atendidos pelos Cursos corporativos de idiomas - 2009 a 2014.

Tabela 14 - Recursos repassados ao DAF e IL à título de custos indiretos - 2009 a 2014. 95

\section{LISTA DE APENNDICES}

Apêndice A - Linhas de Extensão e formas de operacionalização das atividades extensionistas no âmbito da UnB. 112

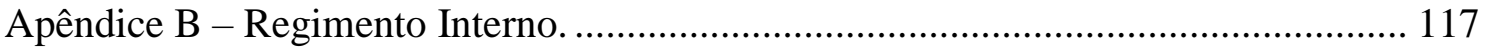

Apêndice C - Questionário de avaliação institucional proposto pelo Interfoco. .......... 132 Apêndice D - Tabela dos Indicadores de Qualidade do Curso de Inglês realizada pelo SIG do UnB Idiomas. 


\section{SUMÁRIO}

INTRODUÇÃ

2 O PAPEL DA UNIVERSIDADE NA SOCIEDADE ........................................... 14

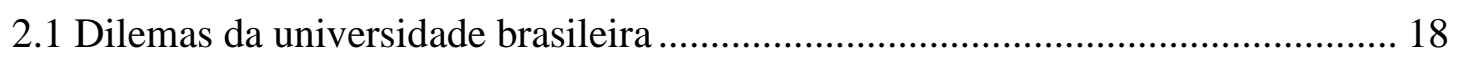

2.2 A trajetória da Extensão Universitária no Brasil ................................................ 23

2.2.1 As diversas concepções da Extensão Universitária....................................... 26

2.3 A Extensão na Universidade de Brasília.............................................................. 30

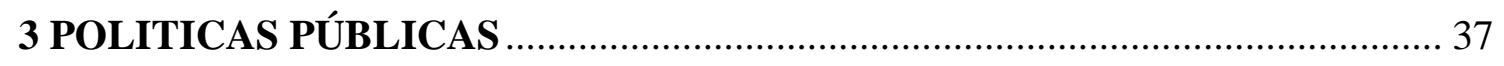

3.1 Considerações teóricas sobre Políticas Públicas.................................................. 38

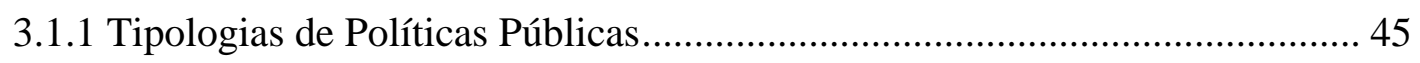

3.2 Critérios de avaliação de Políticas Públicas ........................................................ 50

3.2.1 Metodologias para avaliação da eficácia de Programas ................................ 58

4 ESTUDOS DE CASO: UNB IDIOMAS E SUA EFICÁCIA ................................. 61

4.1 O Programa Permanente de Extensão UnB Idiomas (UnB Idiomas) ................... 61

4.1.1 Projeto de Cursos de idiomas do estágio supervisionado .............................. 63

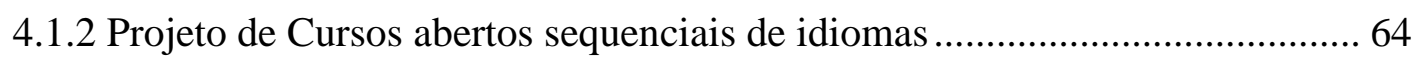

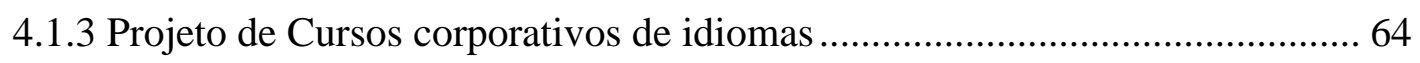

4.1.4 UnB Idiomas - entendendo sua origem e operacionalização........................ 65

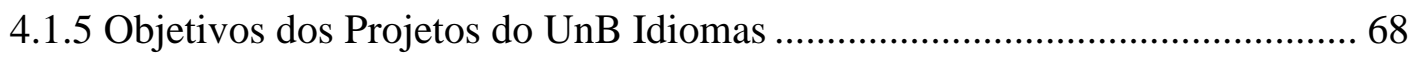

4.2 Eficácias dos Projetos do UnB Idiomas: resultados e discussão .......................... 70

4.2.1 Avaliação do Projeto de Cursos do estágio supervisionado........................... 71

4.2.2 Avaliação do Projeto de Cursos abertos sequenciais de idiomas ................... 75

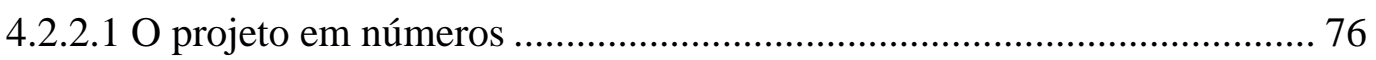

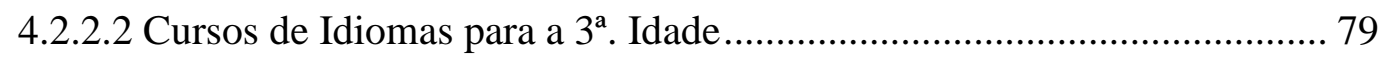

4.2.2.3 Cursos de idiomas com finalidades específicas...................................... 82

4.2.2.4 Cursos de idiomas preparatórios para Exames de Proficiência............... 82

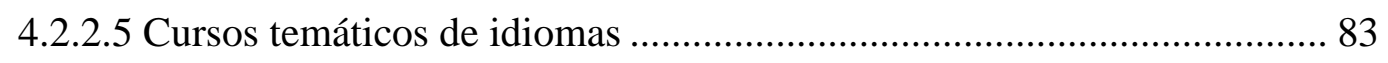

4.2.2.6 Demanda de matrículas dos Cursos abertos sequenciais por campi....... 84

4.2.2.7 Atuação das bolsas ofertadas pelo Programa no período de 2009 a 201486

4.2.2.8 Estudo de caso para um grupo de alunos do idioma inglês .................... 87

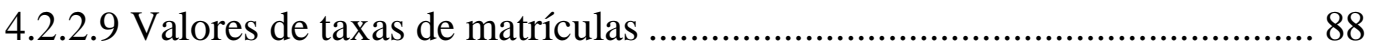

4.2.3 Avaliação do Projeto de Cursos corporativos de idiomas............................. 89 
4.2.4 Análise financeira do Programa 94

4.3 Considerações do Programa à luz das Políticas Extensionista da UnB e do Brasil.

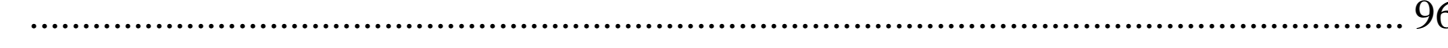

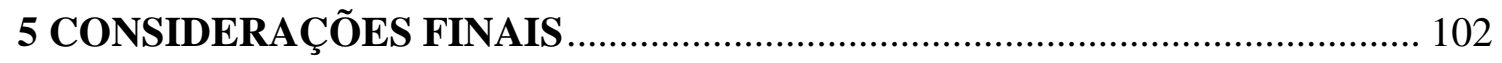

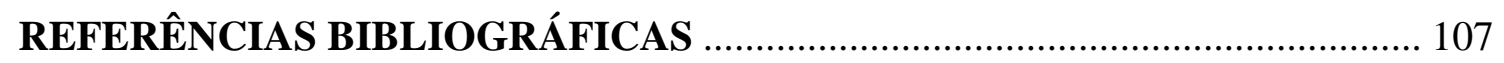

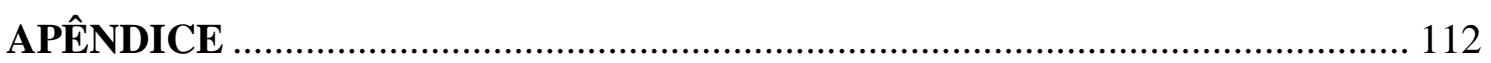

Apêndice A - Linhas de Extensão e formas de operacionalização das atividades extensionistas no âmbito da UnB....................................................................... 112

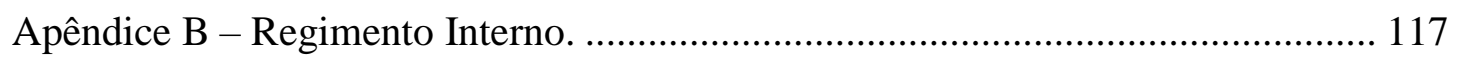

Apêndice C - Questionário de avaliação institucional proposto pelo Interfoco....... 132

Apêndice D - Tabela dos Indicadores de Qualidade do Curso de Inglês realizada pelo

SIG do UnB Idiomas........................................................................................ 134 


\section{INTRODUÇÃO}

Como instituição social milenar, com dedicação para as práticas da produção e perpetuação do conhecimento, das reflexões sistemáticas sobre a realidade em suas diferentes esferas e da formação de profissionais qualificados, a universidade apresenta em sua trajetória histórica as mais diversas transformações, decorrência das mudanças políticas, culturais e econômicas da realidade a qual está vinculada.

Na realidade brasileira, nossa sociedade soube ajustar às funções especificas das instituições de ensino superior os interesses dos mais diversos setores sociais, isso desde as suas primeiras manifestações no século XVIII. Nesse cenário histórico da educação superior brasileira, surgem as universidades públicas federais, projetadas ao longo do tempo como instituições sociais regidas por uma organização própria, sendo que essa sua autonomia recebe reconhecimento com o advento da Constituição Federal de 1998, onde também se vê estabelecida a indissociabilidade entre o ensino, pesquisa e a extensão.

Das três funções universitárias: ensino, pesquisa e extensão, é a extensão a função mais recente, e que surge nas universidades brasileiras influenciada por três movimentos: o das universidades populares surgidas na Europa, que tinham como prerrogativa a disseminação do conhecimento técnico à população não universitária; o do modelo norteamericano de extensão, com a proposta de prestação de serviço e; posteriormente, os apelos do Manifesto de Córdoba, com as reivindicações feitas pelos estudantes para a missão social da universidade.

A maioria dos estudos realizados sobre a extensão tem se dedicado aos aspectos de sua construção histórica e da sua contextualização na universidade como uma terceira função. Têm sido poucos os estudos dedicados a investigar e avaliar a prática das ações extensionistas e suas consequências, tanto no que se refere aos aspectos de sua integração com os processos acadêmicos quanto aqueles que a legitimam frente às demandas sociais.

A falta desses estudos e a complexidade dos elementos que envolvem a extensão oferecem dificuldades para a compreensão da sua concepção, o que decorre, por vezes, em que ela seja confundida como uma prestação de serviços técnicos à comunidade, com fins meramente utilitaristas, sem considerar a sua produção do conhecimento a partir da experiência e a contribuição da sua prática para uma mudança no processo de ensinar e aprender e na incorporação de novos saberes.

A avaliação das ações extensionistas também é um importante instrumento para que sejam verificados seus processos e resultados em relação aos objetivos das políticas instituídas. Ademais, a avaliação pode ser um instrumento fundamental para se alcançar 
melhores resultados e proporcionar uma melhor utilização e controle dos recursos aplicados nos Programas e Projetos extensionistas, como também fornecer aos gestores dados importantes para o desenho de políticas mais consistentes e para uma gestão pública mais eficaz. Além de ser útil para medir a eficácia da gestão pública, a avaliação é decisiva também para o processo de aprendizagem institucional e contribui para a busca e obtenção de ganhos das ações extensionistas em termos de aumento da satisfação do público atendido, estimulo das parcerias internas, e da sua legitimidade social como política extensionista universitária.

Essa via de entendimento fundamentou o objetivo traçado para esta dissertação, estabelecido na avaliação da eficácia da extensão universitária à luz das normas extensionistas praticadas em uma universidade federal e das Políticas de Extensão hoje praticadas no Brasil, tendo como objeto da pesquisa o Programa Permanente de Extensão UnB Idiomas (UnB Idiomas) da Universidade de Brasília (UnB).

O objetivo geral foi avaliar em que medida as atividades extensionistas desenvolvidas pelo UnB Idiomas alcançaram resultados eficazes em relação aos objetivos traçados pela Política extensionista da UnB e pela Política de extensão brasileira.

Buscou-se responder à seguinte questão: as atividades extensionistas promovidas pelo UnB Idiomas contemplam eficazmente os objetivos propostos na política extensionista da UnB e na Política de Extensão brasileira?

Além deste capítulo introdutório, esta dissertação apresenta mais 3 capítulos. No segundo deles, trata-se da história da universidade e da extensão universitária brasileira, além de se apresentar a extensão na Universidade de Brasília.

O terceiro capítulo apresenta uma síntese das principais abordagens teóricas sobre políticas públicas, enfatizando-se os conceitos clássicos e contemporâneos adotados para as mesmas e as suas várias classificações, os métodos adotados para se realizar uma avaliação de políticas.

O quarto capítulo apresenta o estudo de caso, com a descrição sobre a organização das atividades extensionistas do UnB Idiomas, a apresentação dos dados coletados nesta pesquisa e as considerações e análise de eficácia do Programa a partir dos resultados obtidos.

Por fim, apresentam-se as considerações finais a que se chegou a partir da construção desta dissertação e sugestões e recomendações a serem consideradas para a elaboração de futuros estudos. 


\section{O PAPEL DA UNIVERSIDADE NA SOCIEDADE}

Surge na Europa da idade média a ideia de que uma consciência de conservação e perpetuação do conhecimento estivesse confiada a uma instituição especial - universitas magistrorum et escolarium, uma agremiação precursora da universidade constituída por sábios e estudantes que deveriam administrar e perpetuar o conhecimento, reunidos com vontade e desejo de aprender os saberes - os Estudos Gerais. Com esse sentido, a ideia de universidade deu ênfase à conservação e transmissão dos conhecimentos mais do que ao seu progresso, bem como à universalidade do saber mais do que a sua especialização e mais a autonomia da instituição do que ao espírito de serviço para com a sociedade (DRÉZE e DEBELLE, 1983).

Segundo o educador Francisco de Paula Leite Pinto (1968), a função intelectual da Universidade dos Estudos Gerais nasce quando os reis, no sentido de reforçar o poder da realeza, oferecem privilégios ao acrescentar prestígio aos títulos por ela concedidos e essa passa a ser o celeiro dos letrados e peritos. O papel social dos Estudos Gerais foi fundamental para a instituição de normas de direito que não existiam; permitiram a criação de novas classes culturais, elevando a níveis superiores aqueles que pelos estudos adquiriam saberes; e ensinaram que a desigualdade de nascimentos pode ser abolida pela igualdade fraterna entre aqueles que se sentam nos mesmos bancos escolares.

Nos séculos XVI e XVII a instituição não acompanha o ritmo dos acontecimentos históricos do renascimento e, no século XVIII, durante o iluminismo, entra em profunda crise sofrendo reformas radicais em seu projeto e estrutura. Conforme Pinto (1968), os leitores dos Estudos Gerais transmitiam a verdade absoluta, não conhecendo a dúvida que leva a investigação, e foi durante esse período que ousaram pôr em dúvida o que estava fixado nos textos, surgindo então a função investigativa da Universidade.

Para Trindade (2000), é nesse contexto histórico, e com uma forte ingerência do Estado nacional na esfera educacional e do desenvolvimento das ciências, que surge a Universidade moderna. Essa nova relação entre a universidade e o Estado, rompendo o seu formato original, a torna tributária dessa complexa interdependência, e a educação passou a ser vista como um processo formador das elites de poder e dos funcionários dos Estados nacionais nascentes.

Dréze e Debelle (1983), propõem uma categorização das concepções nacionais de universidades em dois grandes grupos. Na Alemanha, na Inglaterra e Estados Unidos numa "ideia de universidade", pois apresentariam uma maior independência em relação aos poderes públicos, estando mais próximas de um modelo dito "liberal", enquanto que 
na França e na Rússia, antiga União Soviética, por seu caráter público e como engrenagem da administração central, se apresentariam como um modelo "funcional".

Ambos os modelos tiveram grande repercussão internacional. Como mesmo destaca Trindade (2000), a concepção francesa de faculdades profissionais isoladas influenciou a educação em outros países, como os países hispanos americanos após a independência, reformulando as estruturas de suas universidades tradicionais. Por sua vez, as universidades de pesquisa, com o seu alto prestígio em vários países do mundo, foram inspiradas no modelo alemão, que garantia a liberdade dos cientistas sob a proteção do estado do qual dependia o seu orçamento. Ainda para o autor, a relevância disso está no início de uma nova relação entre a universidade e o Estado, rompendo com seu formato tradicional e a tornando tributária dessa complexa interdependência.

A partir da metade do século XX são atribuídas funções econômicas à educação com as conhecidas teorias do capital humano. A educação vem associada ao desenvolvimento social e econômico e novas demandas são apresentadas pela sociedade para as Universidades: atuarem como agentes diretos do desenvolvimento econômico e social, além do técnico e científico (TEIXEIRA, 2009).

Sobre isso, Silva (2006, p.199) afirma "que o procedimento pelo qual a universidade se redefine contemporaneamente coincide inteiramente com a sua adaptação às exigências do tempo histórico: mercado, tecnociência, organização eficaz e tecnicismo produtivista".

Na década de 60, o modelo de universidade americana passou a ser imitado por outros países, tanto em termos da massificação do ensino superior quanto em termos de aproximação da universidade com o mercado. Com o surgimento da onda neoliberal na década de 70, os governos europeus passaram a cortar o gasto com o ensino superior e a encorajar as universidades a complementar a receita provinda do erário com a venda de serviços a capitais privados. Os três fins principais da universidade passaram a ser a investigação, o ensino e a prestação de serviços (SINGER, 2001).

Como consequência disto, as funções da universidade foram se tornando cada vez mais complexas, decorrência do atendimento de demandas cada vez mais diversificadas e provenientes de diversos setores da sociedade. Com isso, expectativas foram sendo criadas em relação à universidade, tais como: formar profissionais; desenvolver pesquisa científica; contribuir para o desenvolvimento econômico, social e tecnológico do país; melhorar a qualidade de vida da população; incentivar a cultura e a arte, assessorar o poder público na formulação de Políticas Públicas; prestar serviços e consultorias para o 
aprimoramento das empresas; fornecer informações e análises sobre a economia, dentre outros (CALDERÓN, 2004).

Conforme Teixeira (2009), desse advento emerge um novo papel para a universidade, expandindo seu foco tradicional na formação e capacitação (ensino e pesquisa), agregando à sua missão a atuação direta no processo de desenvolvimento econômico, cultural e social da sociedade. Ao mesmo tempo, enfrenta desafios na direção de gerar as condições para a análise crítica desse processo de criação de valor e suas consequências, tanto internas na própria Universidade, como externas, considerando suas consequências nos planos social, econômico e cultural.

Uma dessas análises refere-se ao real significado da Universidade no papel posterior dos seus recém-formados no desenvolvimento socioeconômico do país, estado ou cidade em que passam a atuar. Seja qual foi o indicador envolvido na análise integração a projetos de pesquisa inovadora em Universidades ou Institutos; participação em empresas modernas e competitivas; e criação de novas empresas de serviços ou tecnologias avançadas, o objetivo será o de contribuir para mudanças tecnológicas, econômicas e sociais que afetem positivamente a riqueza nacional ou regional (FAVADE-MORAES, 2000).

Com relação a essa multiplicidade de papéis que a Universidade vem desempenhando, Botomé (1996) (apud CALDERÓN, 2004) afirma que isto tem feito com que ela se descaracterize, assumindo funções próprias de Organizações não Governamentais, de órgãos públicos ou de entidades assistenciais. Teorizando essa discussão, o autor argumenta que existe uma confusão entre "funções" e "atividades" da universidade, pois o ensino, a pesquisa e a extensão seriam atividades universitárias e não funções da universidade. A função que deveria orientar a universidade é a de produzir conhecimento e torná-lo acessível.

Contrário a esse argumento, Calderón (2004) acredita que tal compreensão representa um impedimento ao desenvolvimento natural da universidade contemporânea, que ficaria então condenada a ser uma instituição anacrônica, distante de seu tempo. Desde a hipótese de que a função da universidade se define a partir do atendimento das demandas do mercado, fica evidente que a demanda pelo ensino é maior do que pela pesquisa. Assim a essência da universidade não é a pesquisa e sim o ensino, formando os profissionais que a sociedade e o mercado necessitam para o seu desenvolvimento.

Para Teixeira (2009), o final do século XX se caracteriza por transformações rápidas e de grande profundidade, que impactam a vida social e trazem novas diretrizes 
que devem assumir a educação superior. O modelo tradicional e o papel da universidade está sendo questionado em razão da sociedade estar mais aberta e competitiva, envolta em redes globais de comunicação e com uma acelerada expansão do conhecimento, avançando em direção a novas formas de trabalho. Ainda para o autor, em uma sociedade baseada na globalização e no conhecimento, a cooperação entre as universidades e os setores produtivos torna-se uma tarefa necessária, já que o diferencial de competitividade de diversas regiões baseia-se nessa aliança consistente entre o mundo gerador do conhecimento e o mundo da produção.

Tendo isso em vista, Carneiro (2014) afirma que as mudanças que mais influenciaram o quotidiano da sociedade atual decorreram da globalização, que impulsionou a sociedade a participar na redefinição de novas relações e, fundamentalmente, de novos modelos de organização. A revolução nos processos comunicacionais tornou a informação disponível a todo mundo de forma quase instantânea. Essas mudanças ocorreram com tal velocidade que ideologias se tornaram obsoletas, profissões se extinguiram e outras foram criadas, reestruturando as sociedades e as relações entre os seus membros.

Embora tenha sofrido profundas alterações na sociedade contemporânea, as universidades guardaram ao longo do tempo um conjunto de características relacionadas ao ensino e a pesquisa. Sobre isso, as discussões a respeito das funções e ao papel da universidade parecem estar divididas entre os que defendem como sendo suas funções básicas a de desenvolver a pesquisa científica, além de formar profissionais, e os que consideram ser sua prioridade a formação profissional. Para Morhy e Cervo (2004), as tendências traçadas nos grandes fóruns de discussões mundiais sobre o que deve ser e para onde vai a universidade são ainda muito confusas, pois os conceitos advindos da universidade antiga misturam-se com os que se foram impondo ao longo da sua história e com as urgências pragmáticas da atualidade.

Segundo Trindade (2000), a compreensão das diferentes dinâmicas universitárias e políticas governamentais é uma tarefa urgente e uma exigência acadêmica e política intransferível para se buscar novos caminhos para a universidade. Ainda para o autor, a comunidade acadêmica tem o dever de debater amplamente a questão e avaliar as implicações de suas medidas, assim como propor alternativas que possibilitem a reforma necessária para garantir o futuro da universidade. 


\subsection{Dilemas da universidade brasileira}

A tardia implantação de um ensino superior em terras brasileiras decorreu das intenções políticas de colonização de Portugal, que entendia ser a colônia incapaz de cultivar as artes e as ciências. Para Fávero (2006), essa resistência também era percebida entre os brasileiros que não viam justificativa para a implantação de uma instituição como essa na Colônia, considerando mais adequado que a elite da época procurasse a Europa para fazer os seus estudos superiores.

Conforme Lopes (2002), mesmo diante de um quadro como esse foram apresentadas no período do Brasil Colônia mais de duas dezenas de propostas e projetos de universidades que não foram aprovados. Em 1789, os programas da Inconfidência Mineira apresentam tentativas de fundar universidades no país, porém todas essas iniciativas foram fracassadas, caracterizando a ação por parte de Portugal de inviabilizar as tentativas de independência cultural e política da Colônia.

A vinda do príncipe regente D. João e sua família provocou mudanças visíveis na estrutura do ensino superior brasileiro, pois nesse momento foram criados os primeiros cursos superiores com sentido profissional prático, como a Academia Real da Marinha, Academia Real Militar e os cursos médicos cirúrgicos da Bahia e Rio de Janeiro. Esses cursos ou escolas foram criados como serviços públicos, mantidos e controlados pelo governo.

A criação dos cursos jurídicos, em 1827, instalados em São Paulo e Pernambuco, foram de grande influência na formação de elites e na mentalidade política do Império, constituindo-se em centros de irradiação de novas ideias filosóficas, de movimentos literários e discussões culturais. Foram, ainda, provedores de quadros para as assembleias do governo das províncias e governo central. (MOREIRA, 1960, p.53, apud FÁVERO, 2006).

Esse modelo de formação profissional das primeiras instituições de ensino superior no Brasil se aproxima do modelo profissionalizante então praticado na França, com a formação voltada para as profissões liberais. Nesse contexto, o Brasil chega ao ano de 1879 com vários estabelecimentos de ensino superior e sem nenhuma universidade. $\mathrm{O}$ que se observa até aquele momento da história brasileira é um ensino superior totalmente público e privativo do poder central, oferecendo ao sistema uma certa imobilidade, pois as possibilidades de ampliação ou diversificação estavam sujeitas à vontade política do poder central. 
Com a proclamação da República e posterior promulgação da Constituição em 1891, o ensino superior é mantido como atribuição do poder federal, mas não de forma exclusiva. De acordo com Fávero (2006), de 1889 até a Revolução de 1930 o ensino superior no país sofreu várias alterações em decorrência da promulgação de diferentes dispositivos legais que possibilitou as condições para o surgimento das universidades, tendendo o movimento a deslocar-se provisoriamente da esfera do Governo Federal para os Estados. Dessa forma são criadas como instituições livres as Universidade de Manaus, em 1909, a de São Paulo, em 1911 e, em 1912 a Universidade do Paraná (MICHELOTTO, 2006, apud FÁVERO, 2006).

Em 1920 é criada pelo Governo Federal a Universidade do Rio de Janeiro, composta pela junção de algumas faculdades profissionais existentes, como as de Medicina, Direito e a Escola Politécnica, sendo-lhe assegurada autonomia didática e administrativa. Apesar das críticas oferecidas pela forma como foi estabelecida, a criação da Universidade do Rio de Janeiro reavivou as discussões em torno do problema universitário no país, especialmente no tocante às funções e ao papel da universidade, com duas posições: daqueles que defendem como suas funções básicas a de desenvolver a pesquisa científica, além de formar profissionais, e os que consideram ser prioridade a formação profissional (FÁVERO, 2006).

A história do ensino superior brasileiro nos mostra que nas décadas de 20 e 30 o ensino superior se dá a partir de grandes escolas profissionais, o que influenciou o perfil das universidades que iam sendo criadas. O poder público esteve sempre presente, sobretudo pela regulação e organização do sistema.

A partir da década de 50, a universidade brasileira sofre uma significativa expansão, sobretudo nas décadas de 60 e 70, resultado do movimento de democratização da universidade. Diversas instituições, em grande parte privadas, foram criadas a fim de promover ajustes na demanda por vagas, atendendo à forte pressão da população que se escolarizava. Eltermann (2012) destaca a atuação do estado na intenção de frear essa expansão dos estabelecimentos isolados de ensino superior, fazendo para isso a sua incorporação em universidades ou em federações de escolas, de forma a facilitar a tarefa de planejamento do ensino superior e buscar um padrão de ensino no país.

O GT (Grupo de Trabalho) criado pelo Decreto $n^{\circ}$ 62.937, de 02/07/1968, teve como objetivo estudar a reforma da universidade brasileira. O Relatório produzido pelo GT atenta ao fato da universidade brasileira estar organizada à base de faculdades tradicionais que, apesar de certos progressos, em substância, "ainda se revela inadequada 
para atender às necessidades do processo de desenvolvimento, que se intensificou na década de 1950, e se conserva inadaptada às mudanças dele decorrentes". Acrescenta ainda: "podemos dizer que o sistema, como um todo, não está aparelhado para cultivar a investigação científica e tecnológica” pois, “(...) mantendo a rigidez de seus quadros e as formas acadêmicas tradicionais, faltou-lhe a flexibilidade necessária para oferecer produto universitário amplamente diversificado e capaz de satisfazer às solicitações de um mercado de trabalho cada vez mais diferenciado" (RELATÓRIO DO GRUPO DE TRABALHO, 1968, apud FÁVERO, 2006).

Segundo Martins (2009), o GT, mesmo não fazendo referência à participação do ensino privado no processo de expansão, possibilitou a sua institucionalização ao permitir a existência de estabelecimentos isolados em "caráter excepcional”, criando as condições favoráveis ao processo de privatização que ocorreu logo em seguida, isso porque os impedimentos financeiros, já invocados no referido Relatório, permitiriam, posteriormente, a invocação da situação de "complementaridade" da rede privada na ampliação do sistema.

Relatando sobre essa escassez de recursos, Martins (2009) afirma que ela não foi impeditiva para a criação, pelo Governo Federal, de um eficiente sistema de fomento para a sua política de desenvolvimento científico-tecnológico, visando a formação de recursos humanos altamente qualificados. Ainda para o autor, a partir dos auxílios financeiros recebidos pelas universidades federais, foi estruturado um modelo duplamente seletivo de universidade federal: no plano social, uma ocupação de suas vagas pela elite e, no plano acadêmico, a associação entre o ensino e a pesquisa na intenção de um elevado padrão de qualidade acadêmica, tendo a pós-graduação um papel central.

Na concepção de Mendonça (2000), as linhas gerais estabelecidas no Relatório do GT forneceram as bases para a elaboração da Lei no 5.540, de 28 de novembro de 1968, na qual a universidade se vê estabelecida como a forma ideal da organização do ensino superior, na sua tríplice função de ensino, pesquisa e extensão, funções essas indissociáveis entre si, especialmente o ensino e a pesquisa, sendo essa última o diferencial da universidade. A função de pesquisa foi o principal fator responsável pela mudança efetiva da universidade brasileira, pois garantiu, por um lado, o desenvolvimento das pós-graduação no âmbito da universidade, e por outro, a melhoria da qualificação dos docentes.

Sob outro enfoque, Silva e Ourique (2012) destacam o fato de que, a partir de 1968, a universidade brasileira, que havia se estruturado a partir dos modelos 
napoleônicos (monopólico estatal, divisão de faculdades compartimentadas e a importância do diploma para o exercício da profissão) e alemão (centralidade no poder intelectual e na autonomia da ciência), recebe a influência do modelo americano, agregando às ações de ensino e pesquisa a utilidade da produção da universidade para o mercado.

A questão central do modelo americano era levar a disseminação e conscientização quanto à utilidade da pesquisa e, dessa forma, a instituição acadêmica pudesse contribuir para o desenvolvimento econômico autônomo do país por meio da produção de ciência e tecnologia e formação de recursos humanos qualificados para a indústria. Com essa expectativa foram elaborados diversos programas para introdução de pesquisa nas Instituições de Ensino Superior.

Para Santos e Almeida Filho (2008), entre os anos de 1981 a 1988, período da redemocratização do Brasil, o sistema universitário público do país vivenciou uma crise econômica, decorrência da diminuição dos financiamentos para as suas atividades e, por uma crise política, em razão do processo de abertura democrática, a qual gerou um ambiente administrativo universitário caótico com longas e frequentes greves de estudantes, docentes e servidores.

A Constituição de 1988, no seu Art. 207, reafirma o princípio de indissociabilidade entre o ensino, pesquisa e extensão para as universidades e estabelece a questão da autonomia universitária. A inclusão da autonomia na Constituição Federal parece ter transferido uma parte importante do debate sobre a educação superior para o campo jurídico, isto porque os debates foram transferidos para a questão da indefinição sobre quais as formas adequadas de controle do poder público para que a universidade cumpra as suas funções de forma compatível com essa autonomia que lhe foi assegurada constitucionalmente.

Também na década de 1980, o campo educacional brasileiro, como também em outros países da América Latina, sofre uma forte atuação do Banco Mundial, do Banco Interamericano de Desenvolvimento (BID) e das agências da Organização das Nações Unidas (ONU). No caso particular do Banco Mundial, é notório o papel que esse organismo exerceu no âmbito educacional ao difundir, entre outras medidas, uma nova orientação para a articulação entre educação e produção do conhecimento, por meio do binômio privatização e mercantilização da educação (DOURADO, 2002).

Sob essas diretrizes dos organismos internacionais são implementadas as reformas educacionais na década de 1990, quando ocorre a retomada da expansão do ensino 
superior como expressão das necessidades políticas e econômicas do desenvolvimento nacional e das demandas sociais. Em decorrência da reforma do Estado implementada com fundamento na doutrina neoliberal, a área educacional se reorganiza dando prioridade para o ensino fundamental e reduz o investimento público para as Instituições de Ensino Superior, induzindo-as à captação de recursos no mercado.

Para Dourado (2002), essa reforma teve como marco referencial a Lei de Diretrizes e Bases da Educação Nacional - LDB, Lei n ${ }^{\circ}$ 9.394, aprovada em dezembro de 1996, a qual foi reveladora de indicativos de políticas para a educação superior brasileira, em especial a fragmentação por meio da diversificação institucional e a expansão pela via do setor privado, acentuando a privatização do ensino superior; e a não-ampliação dos recursos vinculados ao governo federal para esse nível de ensino.

Segundo Santos e Almeida Filho (2008), foi nesse contexto econômico e político do neoliberalismo que surgiu um novo paradigma acadêmico: a universidade corporativa. Esse modelo se estabelece de forma a que a instituição universitária esteja organizada para funcionar como um empreendimento comercial, sob duas variantes: por um lado, resulta do crescimento de centros de ensino superior dentro de uma dada empresa e, por outro lado, implica o desenvolvimento de uma instituição acadêmica como uma corporação.

Segundo Calderón (2004), na intenção de promoção ao debate da ideia da "universidade mercantil”, esse modelo de instituição preconiza a flexibilidade, a diversidade e a variedade. Ademais, o autor identifica esse modelo como contra hegemônico, por entender que, ao invocar a sua condição de empresa - agência prestadora de serviços na área da educação e do conhecimento, oferece diversificados produtos e serviços para atendimento à diversas demandas da sociedade e do mercado, vendo assim a sua missão e suas atividades permanentemente moldadas, definidas e renovadas.

De forma complementar o autor afirma que a universidade mercantil pode assumir as mais variadas formas, tais como: estar dedicada somente ao ensino, ser uma universidade voltada somente para a pós-graduação e pesquisa, uma universidade especializada em alguma área do conhecimento ou uma universidade voltada exclusivamente para o aperfeiçoamento de trabalhadores, graduados ou não, sendo que a sua missão será definida pela missão institucional, pela demanda existente e pela viabilidade financeira (CALDERON, 2004).

No ano de 2006, o Governo Federal encaminhou ao Congresso Nacional o Projeto de Lei $n^{\circ} 7.200$ que trata de uma nova Reforma da Educação Superior. O referido projeto 
de Lei em nada modifica o modelo neoliberal então existente, pois mantém a fragmentação da educação brasileira e concede a autonomia para as universidades públicas na gestão dos seus recursos financeiros, o que, para alguns especialistas da educação, na prática, acabará por forçar essas instituições a se submeterem às leis do mercado e competir como uma verdadeira empresa.

Eltermann (2012) afirma que o pragmatismo decorrente da racionalidade capitalista e privatista do modelo neoliberal, que se expressa na redução do público e na expansão do privado, perdura até os tempos atuais no Brasil. Dessa forma, a educação brasileira permanece tendendo a distanciar-se da responsabilidade do atendimento pelo Estado e continua a transferir para a sociedade civil mais essa função, e o que seria um direito social passa a ter um caráter de mercado econômico.

A crise por que passa a educação superior no Brasil no século XXI parece estar fundamentada nesse movimento crescente de privatização do ensino superior, que vem transformando a universidade pública em um modelo educacional que privilegia a mercantilização do ensino como a principal forma de superação da crise institucional que ela vivencia. De acordo com Martins (2009), ao retomar o projeto de reforma universitária, uma principal questão a ser enfrentada diz respeito à restauração do princípio que atribui à educação superior a qualidade de um bem público, um direito inalienável do cidadão.

\subsection{A trajetória da Extensão Universitária no Brasil}

A História da Extensão Universitária está relacionada à origem das Universidades populares europeias, sob o entendimento de que a universidade precisava contribuir com seu conhecimento para o setor social popular, o que seria possível por meio da extensão da universidade até aqueles setores populares. Essa concepção não foi a mesma adotada na universidade americana, caracterizada pela ideia da extensão como prestação de serviços.

Conforme Paula (2013), essas duas vertentes da extensão universitária estão ligadas a duas modalidades de desenvolvimento capitalista: ao da Europa, na busca da legitimação e estabilidade mediante a implantação do Estado do Bem-estar Social, de forma a oferecer contraponto às consequências do capitalismo; e ao do norte-americano, de vocação rigorosamente liberal, com a mobilização da universidade no enfrentamento de questões referentes à vida econômica, no sentido da transferência de tecnologia e da maior aproximação da universidade com o setor empresarial. 
Na América Latina, as reivindicações do Manifesto de Córdoba, 1918, conclama pela abertura e a sensibilidade das universidades para com os problemas sociais vividos pelos povos latino-americanos. Sob esse contexto, as universidades vão se aproximando da sociedade com a ideia de uma universidade popular, de forma a se redimir do seu distanciamento de um grupo social que não tinha acesso a elas (ROCHA, 2007).

Para Barbosa (2012), percebe-se na prática, e na literatura, a influência dessas três vertentes na trajetória da extensão universitária no Brasil, as quais foram miscigenadas e desenvolvidas conforme a realidade brasileira, sua cultura e política, como veremos a seguir.

As primeiras orientações sobre a Extensão universitária no Brasil aparecem com o Estatuto das Universidades Brasileiras, instituído por meio do Decreto $\mathrm{n}^{\circ} 19.851$, de 1931, quando, então, é apresentada a forma como a extensão deveria ser realizada pelas universidades brasileiras, concebendo-a como "cursos e conferências de caráter educacional ou utilitário" (Art. 42), destinados principalmente a difusão de conhecimento e à solução de problemas sociais. De forma geral, o conceito da extensão fica reduzido à ideia da transmissão do conhecimento (Art. 109), (BRASIL, 1931, apud CABRAL, 2012).

Na compreensão de Viero e Tauchen (2012), o Estatuto das Universidades Brasileiras, apesar da intenção de institucionalizar a extensão, o faz como uma via de mão única, isso porque estabelece para a universidade o dever de "difundir os conhecimentos úteis à vida individual ou coletiva", sem uma identificação clara do que seriam esses conhecimentos úteis e para quem ou qual coletivo eles se destinariam. De forma conclusiva as autoras afirmam o quanto a extensão surge acompanhada por um movimento de verticalização da universidade, onde a função de comunicação se sobressai à da extensão, numa teoria antidialógica e incompatível com uma autêntica educação.

Posteriormente, no ano de 1961, a Lei de Diretrizes e Bases da Educação Nacional reforça o caráter unilateral da extensão como uma forma de difusão do conhecimento ao estabelecer, em seu Art. 69, ser a extensão uma proposta de realização de cursos a serem ministrados pelos estabelecimentos de ensino superior. Essa nova conceituação suprime a ideia de solidariedade e cooperação com a sociedade então refletida na legislação anterior e, mais uma vez, deixa de mencionar a possibilidade da extensão se relacionar com o ensino e a pesquisa, frustrando as expectativas sociais de ter um significado mais profundo para a extensão universitária. (CABRAL, 2012). 
Cabe destaque o trabalho realizado por Paulo Freire na década de 1960, em particular o desempenho realizado no Serviço de Extensão Universitária da Universidade de Recife, que deu clareza sobre a efetiva integração da extensão universitária às grandes questões nacionais à época, fortalecendo o que já vinha sendo feito pelos estudantes na luta pela Reforma Universitária. Sob essas concepções de Paulo Freire, a universidade desperta para o desenvolvimento de instrumentos para aproximação com os setores populares mediante a elaboração de metodologias de interação entre o saber científico e as culturas populares (PAULA, 2013).

Depois dos eventos do início da década de 1960 e, após o período do programa nacional desenvolvimentista do regime militar, a extensão universitária passa por um processo de ressignificação com a reabertura política, na década de 1980, vivendo uma revalorização da participação docente e das iniciativas da extensão propostas pelas universidades, o que permitiu que a extensão buscasse um outro sentido para as suas práticas, em especial no que se refere a avanços para com os modelos tradicionais, dos períodos anteriores, que tinham ações esporádicas, fragmentadas e desvinculadas do projeto político pedagógico das universidades (CABRAL, 2012).

O Fórum de Pró-Reitores da Extensão das Universidades Públicas Federais, criado em 1987, foi decisivo para a construção da atual política de extensão, que passa a ser reconhecida como um elemento do processo acadêmico global que envolve o ensino e a pesquisa, dando destaque à interdisciplinaridade e integrando áreas distintas do conhecimento. A concepção é de que a extensão seja desenvolvida com competência técnico-científica, comprometida com a realidade social.

Em meio a esse cenário é promulgada a Constituição Federal Brasileira, em 1988, que, em seu artigo 207, preconiza a autonomia-didático científica, administrativa e de gestão financeira e patrimonial e a indissociabilidade entre as funções de ensino, pesquisa e extensão universitárias. Essa concepção de ensino superior consagra uma luta histórica dos movimentos sociais em defesa da liberdade acadêmica e de autogestão.

Na década de 90, com a Lei de Diretrizes e Bases da Educação (Lei nº 9394, de 17/12/1996), a educação superior inclui como um de seus princípios a promoção da extensão, aberta à participação da população, visando à difusão das conquistas e dos benefícios resultantes da criação cultural e da pesquisa científica e tecnológica geradas na universidade. Segundo Sousa (2000) (apud BARBOSA, 2012), a LDB não avança na operacionalização da extensão universitária, generalizando-a como um instrumento de difusão das produções e benefícios produzidos pelas universidades à sociedade. 
O Plano Nacional de Extensão Universitária - 1999-2001, elaborado pelo Fórum de Pró-Reitores de Extensão das Universidades Públicas Brasileiras e pela Secretaria de Educação Superior do Ministério da Educação e do Desporto, atualiza uma nova concepção para a extensão, em razão do particular fortalecimento dos setores comprometidos com as classes populares. Com essa redefinição, a produção do conhecimento realizado pela extensão deve ocorrer pela troca de saberes sistematizados, acadêmico e popular, tendo como consequência a democratização do conhecimento, a participação efetiva da comunidade na atuação da universidade e uma produção resultante do confronto com a realidade (PONTE et al., 2009).

\subsubsection{As diversas concepções da Extensão Universitária}

As discussões teóricas que têm acompanhado a historicidade da extensão universitária como função da universidade estão formuladas, conforme Jezine (2002), em três concepções: assistencialista, acadêmica e a mercantilista. Para Viero e Tauchen (2012), em qualquer uma das formas que é realizada, a extensão universitária deve proporcionar a articulação entre a formação acadêmica e o conhecimento produzido na intenção de contribuir com as mudanças sociais.

Desde a concepção assistencialista da extensão universitária, Jezine (2002) afirma que as ações extensionistas caracterizam-se por programas e atividades esporádicas nas comunidades, com soluções imediatistas e paliativas dos problemas sociais, sem uma discussão prévia dos fatores que provocam as desigualdades e sem incentivo a formas de intervenção organizada. Paulo Freire já apontava para o risco dessa extensão assistencialista, na qual a universidade se julga superior no seu saber e a qual tem que ser transmitida sem indagações e confrontos: Educar e educar-se, na prática da liberdade, não é estender algo desde a "sede do saber" a "sede da ignorância" "para salvar, com este saber, os que habitam nesta" (FREIRE, 2006, p.25).

Essa concepção de extensão foi muito aplicada até a década de 1960, seja sob a forma de conferências e cursos para a qualificação de mão de obra, segundo o modelo europeu, seja por meio da prestação de serviços para a área rural, segundo a concepção norte-americana. Viero e Tauchen (2012) afirmam que a extensão com essa abordagem parece ter como propósito o retorno à sociedade daquilo que ela investe na universidade, como uma forma de corrigir a ausência da universidade nas problemáticas da sociedade, sendo que as várias universidades brasileiras que incorporaram essa concepção 
extensionista revelaram um trabalho que "valorizava o conhecimento técnico", mantendo as populações à margem dos processos decisórios.

Com a Lei ${ }^{\circ} 5.540$, promulgada no ano de 1968, assume-se a indissociabilidade entre as atividades de extensão e de ensino e pesquisa e indica-se a prestação de serviços como prioridade das ações extensionistas. Mas é a partir de 1987, com a criação do Fórum de Pró-Reitores de Extensão das Universidades Públicas Brasileiras (FORPROEX), que se inicia no âmbito das universidades uma discussão mais ampla, posicionando a extensão como espaço de elaboração de propostas e diretrizes conceituais, na intenção de fortalecer os princípios acadêmicos da indissociabilidade entre o ensino, pesquisa e extensão; da interação dialógica com a sociedade; e da inter e transdisciplinaridade como princípios organizadores das extensão universitária.

Para Moita e Andrade (2009), o tripé formado pelo ensino, pela pesquisa e pela extensão constitui o eixo fundamental da universidade brasileira e não pode ser compartimentado, visto que a indissociabilidade é um princípio orientador da qualidade da produção universitária. Ainda para os autores, as práticas universitárias não têm sido muito mobilizadoras dessa indissociabilidade, pois ocorrem na maioria das vezes isoladas ou no máximo em relações duais: articulação entre ensino-extensão; ensino-pesquisa; pesquisa-extensão.

Desde essa compreensão, Mazilli (2011), ao reconhecer sobre as dificuldades nas práticas acadêmicas da associação entre ensino, pesquisa e extensão, afirma que essas situações evidenciam que a associação entre elas não se realiza no professor ou no estudante: é uma tarefa institucional, que demanda de uma estrutura organizativa voltada para a superação da fragmentação. A consecução da associação entre ensino, pesquisa e extensão demanda a existência de projetos institucionais que orientem as diretrizes e compromissos das ações previstas, associação das ações acadêmicas e administrativas, práticas de avaliação institucional, gestão que possibilite a participação de todos os segmentos, dentre outros (MAZZILLI, 2005 apud MAZZILLI, 2011).

Outro desempenho da concepção acadêmica da extensão refere-se ao trabalho interdisciplinar com o objetivo de integração das disciplinas com os diferentes saberes das várias áreas do conhecimento, o que vem a possibilitar a pesquisa, a motivar a busca de novos conhecimentos e as percepções das relações existentes entre as diferentes disciplinas, permitindo o desenvolvimento do sujeito como um todo (ROCHA, 2007).

Para Maciel (2010), a inovação pedagógica que a extensão possibilita enquanto prática de ensino deve ser percebida como elemento gerador de conhecimento, desde a 
perspectiva da articulação do ensino com a pesquisa e da relação com a sociedade em geral, seja ela estado, movimentos sociais ou empresas. O autor acrescenta que a extensão universitária enquanto elemento de inovação pedagógica possui, pela pesquisa, além do aspecto da difusão do conhecimento, o potencial de ser direcionada ao estudo dos grandes problemas nacionais.

Mazzilli (2011), ao perceber a importância da extensão para a complementação do conhecimento obtido no ensino superior, chama atenção para o fato de que "a transmissão de conhecimentos no ensino superior, por si só, pode até servir à formação profissional, porém com uma tendência a reduzir-se ao aprendizado de técnicas, sem requerer compreensão do significado social dessa mesma profissão e do profissional que a executa".

Ao observar esse caminho, Moita e Andrade (2009) argumentam sobre o aspecto da renovação da universidade com a perspectiva do conhecimento "pluriversitário", à exemplo do ensino que ganha relevância e significado para a comunidade universitária quando passa a integrar o conhecimento produzido, por meio da pesquisa e dos anseios da sociedade considerados nas atividades de extensão.

A concepção mercantilista da extensão universitária vem sendo realizada pelas mudanças ocorridas na estrutura do Estado e da sociedade, assim como pela intenção da extensão de confirmar-se como uma função acadêmica desde o mesmo nível de valorização do ensino/pesquisa. As suas atuações, na forma de parcerias ou venda de serviços, atendem às demandas advindas da sociedade, que não são mais vistas como carências sociais, mas como novas expectativas de serviços geradas pela sociedade globalizada. A universidade torna-se uma produtora de bens e serviços para os setores da sociedade civil (JEZINE, 2002).

Jezine (2004), avalia que essa concepção é muito questionada pela comunidade universitária porque "traz em seu contexto uma formação ideológica de um projeto de privatização da universidade", especialmente porque ela se dá por meio de pagamento de taxas e outros instrumentos que não representam a identidade de uma universidade pública gratuita. A autora considera, diante da contestação dessa nova concepção teórica e prática da extensão universitária, que também o ensino superior oferecido pelas universidades públicas não atinge com igualdade de acesso a todos que dela demandam, sendo assim, não seria a extensão, com qualquer uma das suas concepções, que poderia solucionar o problema das desigualdades sociais, próprias do sistema capitalista. 
Sobre isto, Soares (2007, p.2) (apud FREIRE, 2011) argumenta ser essa concepção mercantilista a negação da verdadeira essência da extensão universitária, principalmente das universidades públicas, razão pela qual os que lidam com a extensão têm hoje como desafio "a defesa das Políticas Públicas, isto porque não há a conquista de direito pelo mero acesso ao mercado e sim por meio de políticas públicas universais e igualitárias".

Sobre o financiamento para a extensão universitária, Maciel (2010) afirma que qualquer iniciativa governamental de construção de uma política de extensão que se insira numa estratégia mais ampla de desenvolvimento regional e nacional, carece de políticas indutivas que estimulem a sua adoção pelas universidades. Também, para o autor, é grande o potencial de contribuição das universidades com os projetos nacionais de desenvolvimento, contudo essa atuação fica limitada pela ausência de instrumentos normativos que incentivem o segmento, o que impede uma maior abrangência e possibilidades de envolvimento da extensão universitária no contexto das políticas públicas brasileira.

Diante dessa ausência, é afirmado por Maciel (2010) que a incidência de parcerias entre universidades e empresas vem crescendo na mesma proporção com que cresce a importância da tecnologia para o desenvolvimento econômico e social, razão pela qual o processo de transferência de tecnologia das universidades e institutos de pesquisas deve ser estimulado e aperfeiçoado, desde a intenção de alavancar o desempenho do setor produtivo nacional.

No entender de Calderón (2004) o mercado universitário tem provocado profundas mudanças na educação superior, surgindo, dessa nova atuação, conceitos e categorias até então impensáveis no ensino superior, tais como: mercado de ensino, cliente-consumidor e produtos e serviços na área da educação. Ao comentar a aversão de setores acadêmicos em considerar o ensino universitário como um produto ou serviço comercializável, o autor afirma que essa postura se deve à falta de compreensão da academia de aceitar a possibilidade de universidades com perfis diversos, como se a universidade fosse uma instituição monolítica, com um único perfil e, ainda, que esse modelo não tem mais condições de sobrevivência nos tempos atuais, onde os grandes financiadores tem a sua capacidade limitada por crises fiscais, restringindo os investimentos em instituições científicas. 
Todas essas concepções da extensão universitária parecem ter em comum o entendimento de que a definição do que é e a que deve servir a extensão universitária é parte da missão social das universidades, do seu compromisso para com a sociedade.

Sobre isso é compreensão de Serrano (2008) que a prestação de serviços feita pela universidade não deve ser assumida apenas pelo serviço em si, mas deve representar um momento de produção do conhecimento e mesmo de distribuição do conhecimento produzido. É a extensão o instrumento necessário para que o produto da universidade, a pesquisa e o ensino, estejam articulados entre si e possa ser elevado o mais próximo possível das aplicações úteis na sociedade.

\subsection{A Extensão na Universidade de Brasília}

Fávero (2006) afirma que o movimento pela modernização do ensino superior no Brasil, na década de 1960, atinge o seu ápice com a criação da UnB, que surge não apenas como a mais moderna universidade do país naquele período, mas como um divisor de águas na história das instituições universitárias brasileiras, quer por suas finalidades, quer por sua organização institucional. Muitas das ideias lançadas pelo criador e primeiro Reitor da UnB, o antropólogo Darcy Ribeiro, eram o reflexo de várias propostas feitas pelos estudantes reunidos em torno da UNE nos anos sessenta e que tinham sua origem inicial na reforma de Córdoba, Argentina, em 1918, em particular o desenvolvimento da extensão universitária (DIAS, 2002).

Os capítulos especiais do Estatuto e do Regimento Geral da UnB, aprovados pelo Conselho Federal de Educação em 1970, trataram a extensão universitária na UnB sob a ideia de "desenvolvimento de atividades extracurriculares". Ainda naquele ano, o Plano da UnB, aprovado por iniciativa do Reitor Caio Benjamim Dias, daria objetivo à extensão na Universidade de Brasília sob a seguinte referência: “a extensão universitária será desenvolvida através de cursos e serviços oferecidos ao público em geral, com o propósito de divulgar conhecimentos e técnicas de trabalho". O referido instrumento, ao se referir ao corpo discente, estabelecia "a Universidade estimulará sua participação na vida da instituição, através de esportes, programas culturais e cursos e serviços de extensão, proporcionando aos alunos oportunidade de participação em projetos de melhoria das condições de vida da comunidade, bem como no processo de desenvolvimento regional e nacional". (DIAS, 2002).

Ainda no ano de 1970 é criada a primeira Câmara de Extensão da UnB (CEX/UnB). Segundo Dias (2002), no relatório apresentado pelo então Decano à época é 
feita menção a quatro tipos de atividades de extensão desenvolvidas pela UnB durante o ano de 1971: os cursos extracurriculares; a prestação de serviços técnicos; as promoções culturais e reuniões científicas e de estudos.

Posteriormente, em março de 1976, é organizado um seminário interno na UnB, com a participação de representantes de todos os seus departamentos, de forma a avaliar os seguintes temas vinculados à extensão: os cursos, os seminários, as atividades do Projeto Rondon e as atividades de prestação de serviços. Os resultados do referido evento consolidaram uma regulamentação, simples e direta, da extensão na UnB, estabelecida pela Resolução da Reitoria ${ }^{\circ}{ }^{\circ}$ 01/1976 (DIAS, 2002).

Entre os anos de 1977 a 1984, além da realização de atividades de extensão voltadas para cursos, conferências e exposições, das atividades extensionista do Projeto Rondon e das do campus Avançado do Médio Araguaia, é iniciada pelo Decanato de Extensão da UnB (DEX/UnB) uma nova proposta de extensão, que incluía uma série de publicações técnica científicas na intenção da consolidação da Editora UnB e, ainda, é criado o Programa de Ensino a Distância - PED.

Desde o ano de 1985 foram sendo incorporados à extensão novos marcos conceituais e novas diretrizes, fundamentando a atuação da extensão na Universidade e subsidiando a construção do seu projeto político institucional, com o objetivo de estabelecer uma cultura, uma organização processual dessa dimensão acadêmica. De acordo com as normas internas publicadas e divulgadas pelo DEX, verifica-se que elas têm evoluído ao longo dos anos, como pode ser visto no Quadro 1.

\section{Quadro 1 - Normas relacionadas à Extensão Universitária na UnB}

\begin{tabular}{|c|c|c|c|}
\hline Documento & Data & Objetivo & Situação \\
\hline $\begin{array}{l}\text { Resolução do CEPE } \\
\text { n. 016/1987 }\end{array}$ & 05/06/1987 & $\begin{array}{l}\text { Cria e disciplina normas do Progama de Bolsas de } \\
\text { Extensão }\end{array}$ & $\begin{array}{l}\text { Revogada pela } \\
\text { Resolução do CEPE } n \text {. } \\
060 / 2015\end{array}$ \\
\hline $\begin{array}{l}\text { Ato da Reitoria n. } \\
030 / 1987\end{array}$ & & Não localizada & $\begin{array}{l}\text { Revogada pelo Ato da } \\
\text { Reitoria n. } 773 / 1996\end{array}$ \\
\hline $\begin{array}{l}\text { Ato da Reitoria n. } \\
038 / 1987\end{array}$ & & Não localizada & $\begin{array}{l}\text { Revogada pelo Ato da } \\
\text { Reitoria n. } 773 / 1996\end{array}$ \\
\hline $\begin{array}{l}\text { Resolução do CEPE } \\
\text { n. } 022 / 1988\end{array}$ & $31 / 10 / 1988$ & Dispõe sobre as atividades de Extensão na UnB & $\begin{array}{l}\text { Revogada pela } \\
\text { Resolução do CEPE n. } \\
\text { 195/1996 }\end{array}$ \\
\hline $\begin{array}{l}\text { Resolução do CEPE } \\
\text { n. 073/1994 }\end{array}$ & & Não localizada. & $\begin{array}{l}\text { Revogada pela } \\
\text { Resolução do CEPE n. } \\
084 / 1994\end{array}$ \\
\hline $\begin{array}{l}\text { Resolução do CEPE } \\
\text { n. 084/1994 }\end{array}$ & $11 / 11 / 1994$ & $\begin{array}{l}\text { Estabelece a composição e as atribuições da Câmara } \\
\text { de Extensão }\end{array}$ & Vigente \\
\hline
\end{tabular}




\begin{tabular}{|c|c|c|c|}
\hline Documento & Data & Objetivo & Situação \\
\hline $\begin{array}{l}\text { Ato da Reitoria n. } \\
773 / 1996\end{array}$ & 17/05/1996 & $\begin{array}{l}\text { Aprova a Estrutura organizacional do Decanato de } \\
\text { Extensão }\end{array}$ & $\begin{array}{l}\text { Revogada pelo Ato da } \\
\text { Reitoria n. } 1113 / 2012\end{array}$ \\
\hline $\begin{array}{l}\text { Resolução do CEPE } \\
\text { n. 195/1996 }\end{array}$ & $22 / 11 / 1996$ & Define as políticas e diretrizes da Extensão na UnB & $\begin{array}{l}\text { Revogada pela } \\
\text { Resolução do } \\
\text { CONSUNI n. } \\
022 / 2000\end{array}$ \\
\hline $\begin{array}{l}\text { Resolução da CEX n. } \\
\text { 001/1999 }\end{array}$ & 09/09/1999 & $\begin{array}{l}\text { Estabelece normas para as atividades de prestação de } \\
\text { serviços }\end{array}$ & $\begin{array}{l}\text { Revogada pela } \\
\text { Resolução da CEX n. } \\
001 / 2003\end{array}$ \\
\hline $\begin{array}{l}\text { Documento aprovado } \\
\text { pela CEX em sua } \\
\text { 295a. reunião }\end{array}$ & $14 / 10 / 1999$ & $\begin{array}{l}\text { Reestruturação das atividades } \text { de } \\
\text { relacionadas ao Ensino }\end{array}$ & Sem indicação \\
\hline $\begin{array}{l}\text { Documento aprovado } \\
\text { pela CEX em sua } \\
\text { 300a. Reunião }\end{array}$ & $02 / 12 / 1999$ & Define Diretrizes do Decanato de Extensão da UnB & Sem indicação \\
\hline $\begin{array}{l}\text { Resolução da CEX n. } \\
001 / 2000\end{array}$ & $15 / 05 / 2000$ & Não localizada & $\begin{array}{l}\text { Revogada pela } \\
\text { Resolução da CEX n. } \\
001 / 2003\end{array}$ \\
\hline $\begin{array}{l}\text { Resolução da CEX n. } \\
002 / 2000\end{array}$ & $14 / 09 / 2000$ & Não localizada & $\begin{array}{l}\text { Revogada pela } \\
\text { Resolução da CEX n. } \\
001 / 2003\end{array}$ \\
\hline $\begin{array}{l}\text { Resolução da CEX n. } \\
004 / 2000\end{array}$ & $04 / 10 / 2000$ & Não localizada & $\begin{array}{l}\text { Revogada pela } \\
\text { Resolução da CEX n. } \\
001 / 2003\end{array}$ \\
\hline $\begin{array}{l}\text { Resolução do } \\
\text { CONSUNI n. } \\
022 / 2000\end{array}$ & $28 / 12 / 2000$ & Define a Política de Extensão da UnB & Vigente \\
\hline $\begin{array}{l}\text { Resolução CEX n. } \\
\text { 001/2001 }\end{array}$ & $21 / 05 / 2001$ & $\begin{array}{l}\text { Estabelece normas complementares para } 0 \\
\text { encaminhamento de propostas de atividades de } \\
\text { extensão }\end{array}$ & $\begin{array}{l}\text { Revogada pela } \\
\text { Resolução da CEX n. } \\
001 / 2003\end{array}$ \\
\hline $\begin{array}{l}\text { Resolução CEX n. } \\
002 / 2001\end{array}$ & $11 / 09 / 2001$ & Não localizada & $\begin{array}{l}\text { Revogada pela } \\
\text { Resolução da CEX n. } \\
01 / 2003\end{array}$ \\
\hline $\begin{array}{l}\text { Resolução da CEX n. } \\
003 / 2001\end{array}$ & $28 / 07 / 2001$ & $\begin{array}{l}\text { Estabelece normas complementares para } 0 \\
\text { encaminhamento de propostas de atividades de } \\
\text { extensão de Ação Contínua }\end{array}$ & $\begin{array}{l}\text { Revogada pela } \\
\text { Resolução da CEX n. } \\
01 / 2003\end{array}$ \\
\hline $\begin{array}{l}\text { Resolução da CEX n. } \\
001 / 2003\end{array}$ & $04 / 12 / 2003$ & $\begin{array}{l}\text { Estabelece normas gerais para o funcionamento das } \\
\text { atividades de extensão }\end{array}$ & $\begin{array}{l}\text { Revogada pela } \\
\text { Resolução da CEX n. } \\
01 \text { e } 02 / 2012 \\
\end{array}$ \\
\hline $\begin{array}{l}\text { Resolução da Reitoria } \\
\text { n. 077/2004 }\end{array}$ & $17 / 12 / 2004$ & $\begin{array}{l}\text { Regulamenta a expedição de documentação } \\
\text { acadêmica, de capacitação de servidores e de } \\
\text { atividades comunitárias na UnB. }\end{array}$ & Vigente \\
\hline $\begin{array}{l}\text { Resolução do CEPE } \\
\text { n. } 87 / 2006\end{array}$ & $31 / 03 / 2006$ & $\begin{array}{l}\text { Cria a concessão de créditos para os cursos de } \\
\text { graduação }\end{array}$ & Vigente \\
\hline $\begin{array}{l}\text { Resolução do CEPE } \\
\text { n.146/2006 }\end{array}$ & $06 / 06 / 2006$ & $\begin{array}{l}\text { Regula as atividades de extensionistas } \\
\text { colaboradores, sem vínculo empregatício com a } \\
\text { Fundação Universidade de Brasília, participam de } \\
\text { Projetos de Extensão de Ação Contínua na UnB }\end{array}$ & Vigente \\
\hline $\begin{array}{l}\text { Ato da Reitoria n. } \\
497 / 2007\end{array}$ & $07 / 03 / 2007$ & $\begin{array}{l}\text { Cria, na estrutura organizacional do Decanato de } \\
\text { Extensão, o Centro Interdisciplinar de Formação } \\
\text { Continuada (Interfoco), constitui seu Comitê e dá } \\
\text { outras providências. }\end{array}$ & $\begin{array}{l}\text { Revogada pelo Ato da } \\
\text { Reitoria n. } 1113 / 2012\end{array}$ \\
\hline $\begin{array}{l}\text { Ato da Reitoria n. } \\
1189 / 2007\end{array}$ & $06 / 08 / 2007$ & $\begin{array}{lccc}\text { Constitui o } & \text { Conselho } & \text { Científico } & \text { do Centro } \\
\text { Interdisciplinar de } & \text { Formação } & \text { Continuada } \\
\text { (Interfoco), e dá outras providências. } & \end{array}$ & Vigente \\
\hline $\begin{array}{l}\text { Resolução CEX n. } \\
001 / 2007\end{array}$ & $06 / 09 / 2007$ & $\begin{array}{l}\text { Estabelece normas gerais para o funcionamento das } \\
\text { ações de extensão na Universidade de Brasília. }\end{array}$ & $\begin{array}{l}\text { Revogada pela } \\
\text { Resolução da CEX n. } \\
01 \text { e } 02 / 2012\end{array}$ \\
\hline $\begin{array}{l}\text { Instrução da Reitoria } \\
\text { n. } 001 / 2008\end{array}$ & $22 / 09 / 2008$ & $\begin{array}{l}\text { Disciplina os trâmites de convênios, contratos e } \\
\text { outros atos bilaterais dos quais a FUB seja parte. }\end{array}$ & Vigente \\
\hline $\begin{array}{l}\text { Resolução CAD n. } \\
010 / 2008\end{array}$ & $10 / 12 / 2008$ & $\begin{array}{l}\text { Disciplina o exercício de cargos, empregos e funções } \\
\text { por parentes, cônjuges e companheiros }\end{array}$ & Vigente \\
\hline
\end{tabular}




\begin{tabular}{|c|c|c|c|}
\hline Documento & Data & Objetivo & Situação \\
\hline $\begin{array}{l}\text { Resolução da Reitoria } \\
\text { n. } 103 / 2010\end{array}$ & & $\begin{array}{l}\text { Disciplina o pagamento de Pessoa Física por } \\
\text { serviços prestados no âmbito dos projetos aprovados } \\
\text { pela FUB e dá outras providências }\end{array}$ & Vigente \\
\hline $\begin{array}{l}\text { Ato da Reitoria } \mathrm{n} . \\
1113 / 2012\end{array}$ & 09/10/2012 & $\begin{array}{l}\text { Estabelece a estrutura organizacional do Decanato } \\
\text { de Extensão da Universidade de Brasília. }\end{array}$ & Vigente \\
\hline $\begin{array}{l}\text { Resolução da CEX n. } \\
001 / 2012\end{array}$ & $19 / 10 / 2012$ & $\begin{array}{l}\text { Estabelece os fundamentos, os princípios e as } \\
\text { diretrizes para as atividades de extensão da UnB. }\end{array}$ & $\begin{array}{l}\text { Revogada pela } \\
\text { Resolução CEPE n. } \\
\text { 060/2015 }\end{array}$ \\
\hline $\begin{array}{l}\text { Resolução da CEX n. } \\
002 / 2012\end{array}$ & $22 / 10 / 2012$ & $\begin{array}{l}\text { Estabelece os procedimentos operacionais para a } \\
\text { implementação de atividades de extensão na } \\
\text { Universidade de Brasília. }\end{array}$ & $\begin{array}{l}\text { Revogada pela } \\
\text { Resolução do CEPE n. } \\
060 / 2015\end{array}$ \\
\hline $\begin{array}{l}\text { Resolução do CAD n. } \\
002 / 2012\end{array}$ & $14 / 11 / 2012$ & $\begin{array}{l}\text { Estabelece normas para pagamento de auxílio } \\
\text { financeiro a estudante e a pesquisador na forma de } \\
\text { bolsas de estudos, pesquisa e extensão. }\end{array}$ & Vigente \\
\hline $\begin{array}{l}\text { Resolução do CAD n. } \\
004 / 2012\end{array}$ & $13 / 11 / 2012$ & $\begin{array}{l}\text { Normatiza o pagamento, com recursos próprios ou } \\
\text { de terceiros, da Gratificação por Encargo de Curso } \\
\text { ou Concurso (GECC) de que trata o art. } 76 \text {-A da Lei } \\
\text { n. } 8.112 / 1990 \text {, de } 11 / 12 / 1990 \text {, regulamentada pelo } \\
\text { Decreto n. } 6114 / 2007 \text {, de } 15 / 05 / 2007 \text {. }\end{array}$ & Vigente \\
\hline $\begin{array}{l}\text { Resolução do CAD n. } \\
045 / 2014\end{array}$ & $16 / 12 / 2014$ & $\begin{array}{l}\text { Altera os parágrafos } 2 \text { a } 9 \text { do artigo } 4 \text { da Resolução } \\
\text { CAD n. 001/2009 e regulamenta a cobrança dos } \\
\text { custos indiretos e a destinação dos recursos obtidos. }\end{array}$ & Vigente \\
\hline $\begin{array}{l}\text { Resolução do CEPE } \\
\text { n. } 060 / 2015\end{array}$ & $06 / 04 / 2015$ & $\begin{array}{l}\text { Estabelece fundamentos, princípios e diretrizes para } \\
\text { as atividades de extensão na UnB }\end{array}$ & Vigente \\
\hline
\end{tabular}

Fonte: Elaboração própria a partir das informações disponibilizadas pelo DEX/UnB.

O princípio constitucional da indissociabilidade entre o ensino, pesquisa e extensão foi incorporado às normas de extensão desde o ano de 1988, quando também a extensão na UnB passa a se estabelecer como um processo cultural, educativo e cientifico que viabiliza a relação transformadora entre a Universidade e Sociedade (Resolução do Conselho de Ensino, Pesquisa e Extensão/CEPE nº 022/88). Posteriormente, na intenção de atualizar esse postulado, foram incluídos no processo a função interdisciplinar e política da extensão (inclusões feitas pela Resolução CEX nº 01/2012 e mantidas na Resolução CEPE nº 60/2015).

A institucionalização da extensão na UnB tem sido desenvolvida de forma concomitante à normalização das atividades acadêmicas, isto porque os conselhos superiores, ao reformularem os instrumentos normativos e estabelecerem novas diretrizes institucionais, vem contribuindo para a organização e sistematização da extensão universitária, em especial no que se refere a valorização do compromisso da universidade com a comunidade e na ideia da articulação entre o ensino, a pesquisa e a extensão.

A Resolução do Conselho Universitário (CONSUNI) no 22/2000, ainda vigente, oferece um exemplo claro dessa participação quando define sobre os objetivos, natureza, ações, os agentes responsáveis pelas orientações e acompanhamento, e das orientações para a concretização da atuação da extensão na UnB. 
A formulação das políticas e diretrizes da extensão são de responsabilidade do DEX, cabendo à CEX deliberar sobre os planos e propostas relacionados a essas políticas, assim como deliberar sobre o Plano de Desenvolvimento Institucional (PDI) com propostas de ações de extensão das unidades proponentes.

De forma a possibilitar a articulação e fomento das ações de extensão desenvolvidas pelos Institutos e Faculdades, e seus correspondentes Departamentos, foi criada, ainda no ano de 1988, a função de Coordenador de extensão, a quem cabe as orientações, incentivo e supervisão das atividades de extensão no âmbito da sua unidade (Resolução CEPE nº 022/88). O Coordenador de extensão é indicado pela unidade acadêmica (Institutos e Faculdades), com nomeação feita por Ato da Reitoria, e será, preferencialmente, representante da unidade na CEX. Todas as atividades de extensão realizadas pelas unidades acadêmicas devem, obrigatoriamente, dispor da aprovação do Coordenador de extensão.

Em 2012 são consolidadas as diretrizes gerais para a orientação da formulação e implementação das atividades de extensão na UnB, consistidas na interação dialógica, na interdisciplinaridade e interprofissionalidade, na indissociabilidade do ensino, pesquisa e extensão e no impacto na formação do estudante e na transformação social (art. $2^{\circ}$. da Resolução CEX n ${ }^{\circ}$ 001/2012, com redação mantida na Resolução CEPE nº 060/2015).

A articulação com as políticas públicas na atuação da extensão universitária na UnB passa, desde o ano de 2012, a ocorrer sob a concepção de eixos integradores, na perspectiva de ${ }^{1}$ :

a) Eixo Áreas Temáticas: nortear a sistematização das atividades de extensão em oito áreas: Comunicação, Cultura, Direitos Humanos e Justiça, Educação, Meio Ambiente; Saúde, Tecnologia e Produção, Trabalho;

b) Eixo Território: promover a integração, em termos espaciais, das atividades extensionistas, assim como das políticas públicas com as quais elas se articulam;

c) Eixo Grupos Populacionais: promover a integração social em grupos populacionais específicos, especialmente os excluídos e aqueles em situação de vulnerabilidade social.

As atividades de Extensão estão classificadas na UnB como: Cursos de extensão; Eventos; Programas e Prestação de serviços (Resolução Consuni nº 022/2000). No ano

\footnotetext{
${ }^{1}$ Nova redação dada pela Resolução CEPE n. 060/2015.
} 
de 2003 foi incluída a atividade de "Projeto", na intenção de regulamentar as ações formalizadas de caráter educativo, social, cultural, científico, tecnológico ou de inovação tecnológica com objetivo específico e prazo determinado, renovável ou não, vinculado ou não a um Programa, que se integre às linhas de ensino e pesquisas desenvolvidas pela UnB.

As linhas de Extensão e as formas de atuação que integram as atividades dos Cursos, Eventos, Programas, Projetos e Prestação de Serviços encontram-se demonstradas no Apêndice A.

Todas as atividades extensionistas desenvolvidas pela UnB, seja por unidades acadêmicas, seja por Centros e Unidades Descentralizadas, deverão ser obrigatoriamente encaminhadas para avaliação e aprovação da CEX/DEX, obedecendo aos seguintes critérios e normas:

1. devem ter um Coordenador, com comprovada qualificação na área na qual a atividade de extensão esteja inserida, o qual ficará responsável pelo atendimento das normas do DEX. Até o ano de 2014, essa coordenação poderia ser desempenhada por docentes e técnico-administrativo do quadro, ativo e inativo, de servidores da Fundação Universidade de Brasília FUB/UnB. Recentemente, por meio da Resolução CEPE nº 060/2015, somente servidores docentes em efetivo exercício na instituição poderão coordenar as atividades de extensão;

2. devem ter a aprovação do Coordenador de extensão da unidade e a aprovação do Colegiado do Departamento ao qual a atividade está vinculada.

3. devem ser cadastradas no Sistema de Informação de Eventos de Extensão (SIEX) e encaminhadas, com antecedência, para a pré-avaliação da Diretoria Técnica de Extensão (DTE/DEX), caso seja Projeto, e pela Diretoria de Capacitação e Formação Continuada (Interfoco/DEX) quando essas corresponderem a cursos ou minicursos.

4. no caso de Eventos, Cursos e Minicursos deverão ser reservadas, com isenção de taxas de inscrição, 5\% (cinco por cento) do total máximo de vagas, ou 2 vagas, caso o percentual estabelecido represente um número inferior, para contemplar servidores da UnB e estudantes carentes regularmente matriculados na UnB. Essa norma não se aplica para atividades de extensão realizadas no âmbito de Contratos institucionais assinados pela UnB com instituições públicas e privadas. 
5. prever, no plano de aplicação financeira das atividades de extensão realizadas por meio de Contratos interinstitucionais, ou instrumentos congêneres, os custos indiretos que serão incorporados à Fundação Universidade de Brasília, sendo que 50\% deste valor arrecadado será destinado à unidade realizadora da ação extensionista.

A organização das diretrizes e critérios a serem observados na prática da concessão de bolsas para a participação de alunos nas atividades de extensão foram estabelecidas com a criação do Programa de Bolsas de Extensão (Resolução do CEPE n ${ }^{\circ}$. 016/87). Posteriormente novas orientações foram estabelecidas pela Resolução CEX $\mathrm{n}^{\circ}$ 001/2007, Resolução do Conselho de Administração (CAD) nº 002/2012 e, mais recentemente, pela Resolução CEPE n 060/2015, esta última na intenção particular de regulamentar o Programa Institucional de Bolsas de Extensão - PIBEX.

Ao final da atividade extensionista serão expedidos certificados próprios para: o coordenador da atividade; para a equipe de execução; docentes, técnicos, estudantes e membros externos à UnB que participaram das atividades; para os instrutores de cursos e; para os participantes, desde que atingido o critério de aprovação previsto para os Cursos (carga horária mínima de 30 horas). Nas atividades de Cursos e Minicursos poderão ser inseridos como instrutores alunos da graduação, da pós-graduação e profissionais externos à UnB, desde que devidamente aprovados pelo colegiado da área.

O processo de avaliação final das atividades extensionistas se dá por meio de relatórios parciais e finais realizados pelo Coordenador da Atividade, sendo essa avaliação obrigatória no caso particular de atividades que atuam com certificação para os participantes. Esses instrumentos subsidiam a construção de indicadores de extensão na UnB realizada pelo DEX e darão fundamento à consolidação do Relatório Anual de Avaliação a ser elaborado pelo DEX com o apoio de suas diretorias. 


\section{POLITICAS PÚBLICAS}

A relação entre o Estado, representado pelos governantes, e a sociedade, cuja representação é feita pelos cidadãos, está baseada na construção de espaços que criem interfaces na gestão de interesses coletivos, sendo essa participação da sociedade um dos pilares do processo de construção da democracia (NASCIMENTO, 1997 apud COSTA et al., 2009).

É desde essa compreensão que Oliveira (2010) afirma serem as políticas sociais indicadas como instrumentos fundamentais para amenizar as desigualdades originadas no mercado e a inserção dessa proteção social, como parte das ações e projetos que as cristalizam no âmbito estatal, se transforma em política pública, de forma a que não se poderia falar em política pública fora da relação estado e sociedade. Sob essa perspectiva, “o processo de formulação de política pública é aquele por meio do qual os governos traduzem seus propósitos em programas e ações, que produzirão resultados ou as mudanças desejadas no mundo real” (SOUZA, 2003, p. 13 apud OLIVEIRA, 2010).

Para Souza (2006, p.25), do ponto de vista teórico conceitual "a política pública e a política social são campos multidisciplinares, e seu foco está nas explicações sobre a natureza da Política Pública e seus processos". Ainda, segundo a autora, é em razão disso que uma teoria geral da política pública implica na sintetização de teorias construídas no campo da sociologia, da ciência política e da economia, isto porque se há uma repercussão das políticas públicas na economia e nas sociedades requer que em qualquer uma das suas teorias sejam explicadas as inter-relações entre Estado, política, economia e sociedade.

Sobre a definição de política pública, Souza (2006, p.26) a resume como “o campo do conhecimento que busca, ao mesmo tempo, colocar o governo em ação e/ou analisar essa ação (variável independente) e, quando necessário, propor mudanças no rumo ou curso dessas ações (variável dependente)".

Como mesmo afirma Pereira (2005), as políticas públicas são formas de atuação dos governos realizadas por meio de instrumentos reguladores do comportamento do agente econômico. $\mathrm{O}$ autor ainda esclarece que, além dessa função reguladora as Políticas Públicas são adotadas pelo estado também para intervir e incentivar, buscando, assim, a construção de uma sociedade mais justa, mais humana, mais equilibrada e mais coesa, desde os princípios norteadores de combate à ineficiência e de aumento da equidade e da redistribuição. 
Também nessa direção, Gelinsk e Seibel (2008) afirmam serem as políticas públicas ações governamentais destinadas a resolver as necessidades públicas, podendo sua atuação ser social, como no caso da saúde, habitação, educação e outros, e macroeconômica, para a atuação fiscal, monetária, cambial, industrial, e outros e, aquelas com fins diversos, como a área cultural, tecnológica, cientifica.

Na visão de Grau (2009:29) (apud PEREIRA, 2005), as Políticas Públicas são um instrumento de fundamental importância para fazer "entender e explicar os resultados dos "produtos" da ação governamental" e servem como instrumentos de análise da realidade política e administrativa e, por consequência, estão "destinadas a proporcionar percepções e recomendações às instâncias governamentais e administrativas"

\subsection{Considerações teóricas sobre Políticas Públicas}

Conforme Souza (2006), nas últimas décadas a discussão sobre a importância do campo de conhecimento sobre políticas públicas tem recebido destaque, assim como as instituições, regras e modelos que orientam a sua decisão, elaboração, implementação e avaliação.

Ainda na análise de Souza (2006), vários foram os fatores que contribuíram para a visibilidade das políticas públicas, a exemplo de: a) adoção de políticas restritivas de gastos, constantes das agendas da maioria dos países, em especial os em desenvolvimento, as quais deram visibilidade ao desenho e execução das políticas públicas, tanto as econômicas como as sociais; b) novas visões sobre o papel dos governos, aplicando políticas restritivas de gastos em substituição às políticas keynesianas do pós-guerra, implicando na adoção de orçamentos equilibrados e restrições à intervenção do estado na economia e nas políticas sociais; c) falta de coalizões políticas, características de países em desenvolvimento e de democracia recentes, tornando difícil equacionar minimamente propostas de políticas públicas capazes de impulsionar o desenvolvimento econômico e de promover a inclusão social (SOUZA, 2006).

Conforme Pereira (2005) o conceito de políticas públicas se afirma como forma de atuação dos governos traduzidas em instrumentos reguladores do comportamento do agente econômico e os seus princípios são orientados para o combate à ineficiência e para o aumento da equidade e da redistribuição.

Em sua análise sobre políticas públicas Ballart \& Ramió, 2000: 481 (apud PEREIRA, 2005) afirmam que apesar de se pretender, com as políticas públicas, resolver questões eminentemente do foro social, elas não são exclusivas a esse contexto, já que 
também são utilizadas para incentivar comportamentos, para proibir ações privadas e para impor custos a determinados agentes econômicos, com o objetivo de compensar ou de punir os comportamentos do cidadão. Desde essa compensação, Pereira (2005) esclarece estar ela relacionada com a produção de externalidades positivas, que trarão benefícios para a sociedade e, no que se refere ao aspecto da punição a situação é inversa, pois se refere a necessidade de inibir a produção de externalidades negativas, onde um sacrifício social é imputado à população, sendo a punição uma forma de controle e de regulação do próprio mercado.

Em consoante a isto, Silva (2015) afirma que quando mercados falham, políticas governamentais devem ser implantadas de forma a superar essas falhas e promover o bem-estar da sociedade como um todo. Além das externalidades, como acima demonstrado, as falhas de mercado se apresentam também tipificadas como: bens públicos, mercados incompletos, informações assimétricas, comportamento não competitivo e não convexidade (DASGUPTA e MÄLER, 2004; PERMAN et al., 1999; PINDYCK e RUBINFELD, 2004 apud SILVA, 2015).

Sobre a atuação do poder público, Roura (1997) afirma que é por meio da persuasão, do estímulo e da regulação, ou regulamentação, que os poderes públicos poderão adequar o comportamento dos agentes públicos e sociais aos objetivos das Políticas almejadas. Estas três vias estão estritamente ligadas e quanto maior for o nível de participação melhor será o estimulo e a regulamentação.

Em seus estudos, Pereira (2005) chama atenção para a dificuldade do setor público em mensurar os objetivos para as diferentes políticas arquitetadas, o que ocorre em razão de que os contextos que envolvem as políticas públicas são, por vezes, específicos, acontecendo deles próprios se transformarem em instrumentos limitadores da ação da própria política. Assim, é necessário que haja uma sintonia entre os objetivos da intervenção pública e os objetivos específicos de uma política pública muito particular, caso contrário poderá inviabilizar a atuação e os objetivos dessa política.

Na avaliação de Serafim e Dias (2012, p. 124) a "forma com que se entende uma política pública está diretamente relacionada com a percepção que se tem do Estado”. Para os autores há uma compreensão simplista de que o Estado atua de forma autônoma na condução das políticas públicas, sob a ótica de que as ações decorrentes dessas políticas beneficiariam a toda a sociedade, sem considerar para isso que as ações, ou não ações, do Estado são reflexos do comportamento dos atores que nele atuam. 
Ainda para os autores, os atores inseridos no Estado dispõem de interesses, valores, ideologias e projetos políticos distintos e, sendo o Estado um ambiente de sistemática disputa política não deve ser ele compreendido como um ente independente da sociedade e imune aos conflitos que nela se manifestam (SERAFIM e DIAS, 2012).

Desde a análise dos interesses coletivos para a elaboração de políticas, alguns modelos foram desenvolvidos por diferentes áreas do pensamento econômico, na intenção de capturar os aspectos essenciais dos determinantes e da dinâmica dos padrões de interação sociais envolvidos nas políticas públicas, a exemplo do quadro paradigmático da escolha racional desenvolvido por Arrows (1970), onde o papel do governo seria o de maximizador do bem estar social, considerando, para isto, o conjunto de preferências individuais, sendo, portanto, as políticas justificadas quando existe uma situação marcada por falhas de mercado. Outro modelo é o da teoria da Escolha Pública (Tullock, 1986; Buchanan, 1977), cuja corrente está afinada aos pressupostos neoclássicos e onde as políticas públicas são o resultado de um processo político que busca alinhar as preferências dos agentes com os interesses das organizações e instituições. (FLEXOR e LEITE, 2007).

Muitos são os estudos que tratam sobre o conceito de políticas públicas, com destaque para o de Mead (1995), que as define como um campo de estudos da política que analisa o governo à luz de grandes questões públicas; o de Lynn (1980), definido como um conjunto de ações do governo que produzirá efeitos específicos; o de Peters (1986), estabelecido como a soma das atividades do governo, que agem diretamente ou por meio de outrem, e que influenciam a vida dos cidadãos; o de Dye (1984), que sintetiza a definição de políticas públicas como o que o governo escolhe fazer ou não fazer (SANTOS PAULA, 2013).

O conceito mais tradicional é o de Laswell (1984) (apud CARDOSO, 2011), que apresenta o pressuposto de que para a configuração de uma política é necessário definir quem decide o quê, quando, com que consequências e para quem, e que, sendo essas definições relacionadas à natureza do regime político em que se vive, ao grau de organização da sociedade civil e à cultura política vigente, faz-se necessária uma 'policy analysis' ou análise de políticas, para assim se configurar uma política.

O conjunto de elementos constituídos pela análise de políticas (policy analysis) possibilita uma visão explicativa/normativa sobre o processo de elaboração de políticas públicas, onde também são enfatizados aspectos como os valores e interesses dos atores envolvidos, da interação entre eles, a tomada de decisões, conflitos e negociações. Trata- 
se de um estudo sobre a ciência do estado em ação ou, mais precisamente, uma metodologia de investigação social aplicada à análise da atividade concreta da autoridade pública (ROTH DEUBEL, 2006 apud SERAFIM e DIAS, 2012).

$\mathrm{Na}$ intenção de facilitar o entendimento do processo de elaboração da Política Pública, o instrumental da análise política, ou 'policy analysis', diferencia três dimensões da política, as quais são apresentadas com o emprego dos seus conceitos em inglês, são elas: a dimensão institucional 'polity', que se refere às instituições políticas e ao sistema político; a dimensão processual 'politics', referente ao processo político e; a dimensão material 'policy', para os conteúdos das políticas no que se refere à configuração dos programas políticos, aos problemas técnicos e ao conteúdo material das decisões políticas (FREY, 2000).

Serafim e Dias (2012) identificam que a materialização de uma política pública passa por alguns momentos de maturação e que a modelização do processo de elaboração de uma política é denominada de ciclo da política ('policy cycle'). Os autores, a partir dos conceitos de autores como DYE, 1984; FREY, 2000; JONES, 1970; MENY; THOENIG, 1992, apresentam o ciclo com uma divisão em cinco momentos sucessivos, interligados e dinâmicos: 1. Identificação de problemas; 2. Conformação da agenda; 3. Formulação; 4. Implementação e; 5. Avaliação da política, conforme apresenta a Figura 1:

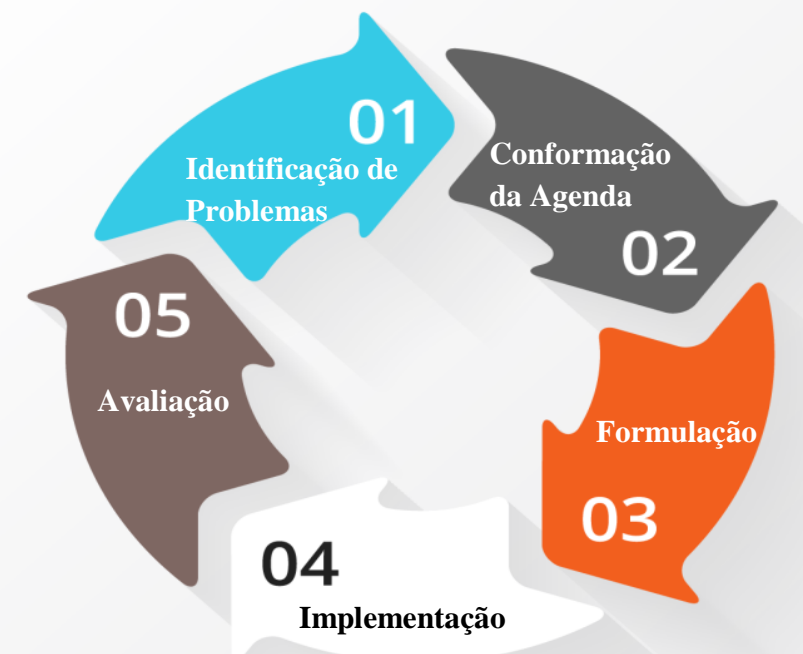

Figura 1 - Ciclo da política

Fonte: elaboração própria, a partir de Serafim e Dias (2011). 
Sobre o momento de identificação dos problemas, que foi incorporado recentemente no ciclo da Política, esse constitui um dos principais focos dos estudos das análises de política (policy analysis), pois nele são observados com maior clareza as assimetrias de poder, tensões entre as agendas e conflitos encobertos ou latentes (SERAFIM E DIAS, 2012).

Os problemas são definidos por Dery (1984) (apud SERAFIM e DIAS, 2011) como sendo: problema como situação - problemas como uma simples situação não desejável ou um simples estado de dificuldade; problema de discrepância - são definidos como a discrepância do que é e o deveria ser, isto é, todos compartilham da mesma concepção do que deveria ser e as suas soluções; problema como discrepância solucionável - define uma solução intermediária entre as definições anteriores. Nesse caso, compreende-se que a solução de um problema melhoria a situação atual, mas não levaria a uma situação ideal e; problema como oportunidade - onde se compreende que os problemas são subjetivos e difíceis de serem identificados, necessitando uma construção analítica sobre eles.

Viana (1997, p. 9) afirma que "o reconhecimento de problemas se daria em função de indicadores, eventos, crises, símbolos e processo de feedback do trabalho burocrático e da elaboração do orçamento". Nem sempre as emergências decorrentes de eventos ou crises são suficientes para a entrada de um assunto na agenda, isto porque nesse processo anterior de formação e formulação de ideias somente algumas irão satisfazer os critérios estabelecidos pelos grupos de especialistas, sendo assim, a sobrevivência de uma ideia ou um assunto dependeria de sua factibilidade técnica; de sua aceitação pelos grupos de especialistas e pelo público; e da força de consenso que ela mobiliza (KINGDON, 1984 apud VIANA, 1997).

A partir da análise de vários autores, se pode afirmar que os agentes interessados são os principais atores que se preocupam com a identificação dos problemas públicos. Se há a identificação do problema por algum desses atores políticos, esses atuarão no sentido de que tal problema entre na lista de prioridades de atuação para a sua resolução, e essa lista de prioridades é denominada Agenda.

Segundo Pérez e Seisdedos (2006) (apud SERAFIN e DIAS, 2011), de um modo geral os atores que intervêm no processo de conformação da agenda são classificados em dois grandes grupos: os atores e o público. Os atores são aqueles que participam da conformação da agenda de acordo com a sua relação com o problema, sendo os principais atores o legislativo, o governo, a administração pública os grupos de interesses, os 
partidos políticos e os grupos de especialistas. O público é composto por espectadores e beneficiários-fins da política pública, ou seja, os cidadãos.

Kingdon (1984) (apud VIANA, 1996), diferencia três tipos de agenda de atenção governamental: sistêmica ou não-governamental, que contempla a lista de assuntos de preocupação do país há tempos, sem, contudo, merecer atenção do governo; governamental: que inclui problemas que merecem atenção do governo e; a de decisão: com a lista dos problemas a serem decididos. Para o autor, na ocorrência de crises, um assunto pode ir da agenda sistêmica para a agenda governamental, razão da influência de um quadro de indicadores ou acumulação de informações e experiências.

Não obstante a relevância da ação, é somente na fase da agenda que se decide se um tema efetivamente vai ser inserido na pauta política atual ou se o tema deve ser excluído ou adiado para uma data posterior. A decisão precede de pelo menos uma avaliação preliminar sobre os custos e benefícios das várias opções disponíveis da ação, assim como, de uma avaliação da imposição do tema ou projeto na arena política, onde é importante o envolvimento dos relevantes atores políticos (KINGDON (1984), apud VIANA, 1996).

Na análise de Hofferbert (1974) (apud VIANA, 1996), os condicionantes que fornecem os limites de forma e magnitude para o processo de formação de políticas são os meios socioeconômico e político, sendo que algumas políticas são determinadas mais pelo meio e outras mais pelas rotinas e padrões de atuação implícitos nas instituições. O autor ainda considera que o meio sócio econômico corresponde às externalidades da agenda.

Em suas análises, autores como Hoppe, Van de Graaf e Van Dijk (1985) (apud VIANA, 1997), identificam que a fase da formulação pode ser desmembrada em três subfases: a primeira, quando um conjunto de dados é transformado em informações relevantes; a segunda, quando valores, ideais, princípios e ideologias se combinam com informações factuais para produzir conhecimento sobre a ação orientada; e a última, quando o conhecimento empírico e normativo é transformado em ações públicas.

Na perspectiva de Mondragón (2006) (apud SERAFIM E DIAS, 2011), seriam dois os momentos em que a formulação acontece: o primeiro momento é o processo decisório, no qual os atores políticos, com base em variáveis diversas (políticos, governamentais, ideológicos, etc.), influenciam de forma considerável a escolha das alternativas e o esqueleto da política pública. O segundo momento refere-se ao processo 
formal, em que a decisão do primeiro momento se configura em política pública por meio de medidas administrativas.

Para Serafim e Dias (2011), no momento do estabelecimento dos objetivos da política pública, os políticos, os agentes públicos e demais atores envolvidos no processo resumem o que esperam que sejam os resultados da política. A definição de objetivos é fundamental para nortear a construção de alternativas e as posteriores fases de tomada de decisão e, quanto melhor definidos esses objetivos mais fácil será verificar a eficácia da política instituída.

A literatura apresenta diferentes concepções sobre como o processo de implementação acontece, tendo como foco central para isto quem toma as decisões, ou seja, se elas vêm de cima (visão top down) ou se as mesmas são reconstruídas (ou reformuladas) a partir de baixo (visão bottom up). A discussão está centrada na análise de quais atores têm influência e quais os impactos que cada um desses atores produzirá nos resultados da política (LOTTA, 2010).

No momento em que se começou a verificar o resultado das políticas, percebeuse que alguns fatores decorriam do processo de implementação que apresentavam falhas como, por exemplo, problemas na falta de clareza dos objetivos e dos programas, que levavam a interpretações diversas; o envolvimento de vários atores e agências na implementação, dando consequências aos processos de coordenação e comunicação. Sobre isto, Carvalho (2003:186) (apud, TREVISAN E BELLEN, 2008) salienta que ao se considerar o sistema das políticas públicas como um processo em fluxo, é necessário que as ações políticas sejam organizadas em um modelo consecutivo de interação.

O modelo do processo decisório proposto por Van Meter e Van Horn (1975) (apud VIANA, 1997) para a etapa de implementação, indica que o desempenho da política depende das características das agências implementadoras, tamanho e competência da equipe, das condições políticas, econômicas e sociais e da forma de execução de atividades, que dependem da clareza com que as metas e objetivos são estabelecidos. No que se refere as condições políticas, econômicas e sociais estas dependem dos recursos econômicos disponíveis, do reflexo das condições econômicas e sociais, e ainda da opinião e da posição dos agentes de interesse.

O Comitê de Ajuda ao Desenvolvimento da Organização para a Cooperação e Desenvolvimento Econômico (CAD/OCDE) esclarece que o propósito da avaliação é de determinar a pertinência e alcance dos objetivos, a eficiência, efetividade, impacto e sustentabilidade do desenvolvimento. A avaliação deve proporcionar informação que seja 
crível e útil para permitir a incorporação da experiência adquirida no processo de tomada de decisão. Em outras palavras, a avaliação deve ser vista como um mecanismo de melhoria no processo de tomada de decisão, a fim de garantir melhores informações, sobre as quais eles possam fundamentar suas decisões e melhor prestar contas sobre as políticas públicas (ALA-HARJA E HELGASON, 2000 apud TREVISAN e BELLEN, 2008).

Na concepção de Worthen et al. (2004) (apud OLIVEIRA, 2012), a avaliação significa identificar, esclarecer e aplicar os critérios defensáveis para determinar o valor ou mérito, a qualidade, a utilidade, a eficácia ou a importância do objeto avaliado em relação a esses critérios. São diversos os autores que destacam sobre não se considerar a avaliação apenas como o ato de medir, comparar ou julgar, visto que ela é muito mais do que isso, pois detém importância social e política, o que é crucial no aperfeiçoamento de qualquer gestão.

Em nossa avaliação, no caso da atribuição de valor, nos parece ser este um aspecto consensual na definição de avaliação, isto porque a avaliação se manifesta como um processo investigativo da qualidade de alguma ação ou fato, onde é atribuído um valor ou qualidade a partir de um determinado critério ou de algum referencial, de forma a produzir um panorama efetivo da sua atuação em números ou padrões assumidos como válidos para aquela ação.

É na fase de avaliação que são investigados os déficits de impacto e os efeitos colaterais indesejados, os quais oferecerão consequências para as ações e programas futuros. Decorrência da sua aplicação, caso os objetivos do programa tenham sido atendidos o ciclo pode ser suspenso ou chegar ao fim, ou então dar início a um novo ciclo, isto é, a uma nova fase de percepção e definição de problemas (FREY, 2000:229 apud TREVISAN E BELLEN, 2008).

\subsubsection{Tipologias de Políticas Públicas}

As políticas públicas se organizam sob um complexo ambiente de variáveis, as quais transmitem a essência dos conteúdos das Políticas e facilitam o exercício da análise das ações do governo. Conforme Rua e Romanini (s.d.), na intenção de lidar com essa complexidade foram criadas várias tipologias como instrumento de classificação, permitindo o enquadramento das políticas em uma ou outra moldura, isto a partir do exame das características observáveis de um dado objeto (suas variáveis), tornando 
possível o exame das políticas com base em diferentes combinações de distintas variáveis, que constituem as diversas tipologias encontradas na literatura.

A mais influente tipologia é aquela proposta por Lowi $(1964,1970,1972)$, que classifica as políticas em distributivas, regulatórias, redistributivas e constituintes. De forma a fundamentar essa classificação, o autor ressalta os grandes problemas para a identificação dos tipos, áreas ou grandes categorias de políticas públicas, ao tempo em que afirma que a sua definição seria oferecida por meio do impacto sobre a sociedade ou o impacto esperado. As ações governamentais corresponderiam a arenas reais de poder, com características próprias, estrutura política etc.

As contribuições de Lowi (1964) são absorvidas por diversos autores, mas é no trabalho de Salisbury (1968) que elas são mais aprofundadas e ampliadas com a política auto regulamentada - o Estado limitando o livre acesso a uma profissão e, dessa forma, acrescentando privilégios a um tipo de público (SOUZA, 2010).

Na avaliação de Hofferbert (1974) (apud VIANA, 1997) as tipologias criadas para a classificação de políticas, como as de Lowi (1964), Salisbury (1968) e as de Eulau e Eyestone (1968), são mais apropriadas para os estudos de avaliação de políticas, sendo que para auxiliar o estudo do processo decisório é preciso classificar essas tipologias de outra forma, segundo os tipos e estruturas comuns de determinação.

Conforme Serafim e Dias (2012), a compreensão de uma política pública, para além da identificação de seu conteúdo, deve agregar a assimilação de seus propósitos, seus beneficiários, os atores envolvidos e seu desenho - importantes fatores para se captar a sua conformação e complexidade. Vários autores sugerem diferentes modelos de avaliação ou diferentes categorias de dimensões para agrupar tais modelos, na intenção de criar um referencial teórico. O Quadro 2 apresenta os tipos de políticas mais comuns na literatura e a essência de seus conteúdos e de seus elementos de análise. 
Quadro 2 - Caracterização de tipos de Políticas Públicas por critérios de abrangência.

\begin{tabular}{|c|c|c|}
\hline Abrangência & Tipos de Políticas & Classificação \\
\hline \multirow{4}{*}{$\begin{array}{l}\text { Critérios que abrangem as } \\
\text { dinâmicas e agendas próprias de } \\
\text { cada área setorial, os atores que nela } \\
\text { atuam com seus objetivos e recursos } \\
\text { de poder diferenciados e a forma } \\
\text { predominante de organização dos } \\
\text { interesses em cada área. }\end{array}$} & SOCIAIS & $\begin{array}{l}\text { Política de governo que intervém na economia de mercado visando o bem-estar e elevação do padrão } \\
\text { de vida do cidadão (Marshall, 1967). Ex.: Educação, Saúde, etc. }\end{array}$ \\
\hline & ECONÔMICAS & $\begin{array}{l}\text { Atuação e influência do governo sobre os mecanismos de produção, distribuição e consumo de bens e } \\
\text { serviços. Ex.: Política monetária, cambial, fiscal, etc. }\end{array}$ \\
\hline & DE INFRAESTRURA & $\begin{array}{l}\text { Assegura as condições para a implementação e a consecução dos objetivos das Políticas Sociais e } \\
\text { Políticas Econômicas. Ex.: Politica rodoviária, de energia elétrica, saneamento básico, etc. }\end{array}$ \\
\hline & DE ESTADO & $\begin{array}{l}\text { Cumprimento do papel fundamental do Estado. Visam garantir o exercício da cidadania, a ordem } \\
\text { interna e a defesa externa para as condições de defesa da soberania nacional. Ex. Políticas de direitos } \\
\text { humanos, segurança pública. }\end{array}$ \\
\hline \multirow{4}{*}{$\begin{array}{l}\text { Critérios relacionados aos impactos } \\
\text { que a política pública pretende ter } \\
\text { na sociedade. } \\
\text { Autor: Lowi }(1964 ; 1970) \text {. }\end{array}$} & REGULATÓRIAS & $\begin{array}{l}\text { Determinam os padrões de comportamento da sociedade e dos próprios agentes públicos. Podem variar } \\
\text { de regulamentações simples e operacionais a regulamentações complexas e abrangentes. Ex. Código } \\
\text { de trânsito, Código Florestal, Legislação trabalhista, etc. }\end{array}$ \\
\hline & DISTRIBUTIVAS & $\begin{array}{l}\text { Direcionam recursos difusos da coletividade para grupos específicos de interesses, gerando impactos } \\
\text { positivos mais individualizados. Podem ser assistencialistas ou não. Ex. Implementação de hospitais e } \\
\text { escolas, salário desemprego, etc. }\end{array}$ \\
\hline & REDISTRIBUTIVAS & $\begin{array}{l}\text { Concedem benefícios a um grupo social específico, retirando recursos de outros grupos também } \\
\text { específicos. Ex. Reforma agrária; Política tributária, etc. }\end{array}$ \\
\hline & CONSTITUTIVAS & $\begin{array}{l}\text { Definem as regras, os procedimentos que irão moldar o funcionamento do governo. Ex.: Regras } \\
\text { constitucionais; Regimento do Congresso Nacional }\end{array}$ \\
\hline $\begin{array}{l}\text { Critérios de relação entre as } \\
\text { modalidades de políticas e o seu } \\
\text { contexto institucional, composto } \\
\text { pelo sistema decisório e pelo padrão } \\
\text { de demandas. } \\
\text { Autor: Salisbury (1968) }\end{array}$ & $\begin{array}{l}\text { AUTO } \\
\text { REGULATÓRIAS }\end{array}$ & $\begin{array}{l}\text { Os padrões de demandas integradas ou fragmentadas e as decisões do sistema mudariam em função } \\
\text { dos recursos do sistema, o que repercutiria nos resultados políticos. Ex.: Mercado de capitais, etc. }\end{array}$ \\
\hline \multirow{3}{*}{$\begin{array}{l}\text { Critérios definidos na ideia da } \\
\text { relação custo-benefício. } \\
\text { Autores: Salisbury e Heinz (1970) }\end{array}$} & ALOCATIVAS & $\begin{array}{l}\text { Emprego de uma parcela dos recursos da economia (capital, trabalho e recursos naturais diversos) para } \\
\text { oferta e ou provisão de bens e serviços tidos públicos. Os benefícios são diretos, materiais ou simbólicos } \\
\text { para indivíduos e grupos Ex. Saneamento básico, energia, fornecimento de água, etc. }\end{array}$ \\
\hline & ESTRUTURAIS & $\begin{array}{l}\text { Mais ambíguas nos seus efeitos, podem variar entre os resultados regulatórios e auto regulatórios, } \\
\text { estabelecem estruturas de autoridade ou regras para alocaçóes posteriores. }\end{array}$ \\
\hline & MAJORITÁRIAS & Os custos e benefícios são distribuídos a toda a coletividade. Ex.: Segurança Pública, Educação, etc. \\
\hline
\end{tabular}


Critérios segundo a distribuição ou concentração de custos e benefícios a toda a coletividade ou a grupos de interesses.

Autor: Wilson (1973)

Critério estabelecido na ideia de que as decisões do governo seriam apenas incrementais e pouco substantivas.

Autores: Lindblon (1979); Caiden e Wildavsky (1980)

Critérios estabelecidos desde a intenção dos governantes de implementar suas decisões políticas e da disponibilidade de conhecimento para a formulação e implementação da Política Pública. Autor: Gustafsson (1983)

Fundamentada em categorias sobre as ideias de grau de impacto nas pessoas e de complexidade Autor: Gormley (1986)

Critérios estabelecidos na relação da Política Social com a cidadania regulada pelo estado e vinculada as profissões-

Autor: Santos (1987)

Critérios de abrangência dos benefícios
EMPREENDEDORAS

Propõe benefícios coletivos a partir de custos concentrados em poucos grupos. Implicam mudanças que oneram uns em benefício de outros. Ex.: Reforma administrativa, Política Ambiental, etc.

CILNTELISTAS $\quad$ Os custos são coletivizados, mas os benefícios são destinados a poucos grupos. Ex.: Subsídios, Renúncias Fiscais, etc.

GRUPOS DE $\quad$ Custos e benefícios concentrados em grupos antagônicos, ou seja, alguns grupos arcam com todo o

INTER custo e outros grupos recebem todo o benefício. Ex.: Reforma agrária; Política Tributária, etc.

INCREMENTALISTA

Os recursos governamentais partem de decisões marginais e incrementais, sem considerar as inovações políticas ou mudanças substantivas nos programas.

REAIS

SIMBOLICAS

Os governantes possuem a intenção efetiva de realizar e detém o conhecimento técnico requerido para isto.

\section{PSEUDOPOLÍTICAS} intenção de implementá-la.

SEM SENTIDO

DE SALAS OPERATÓRIAS

DE AUDIENCIA

DE SALA DE REUNIÕES

DE BAIXO ESCALAO

PREVENTIVAS COMPENSATÓRIAS

SOCIAIS $\quad$ Redistribuição de renda e benefícios sociais.

ESTRUTURAIS Interferem em relações estruturais como renda, emprego, produtividade, etc. Ex.: Política de geração

Os governantes não têm o interesse na implementação da política e também não conta com os conhecimentos técnicos necessários para a sua elaboração.

Políticas de alta complexidade técnica e tem muita visibilidade. Ex.: Política de Medicamentos; Legislação sobre transgênicos, etc.

Políticas de baixa complexidade. Sua formulação não demanda de conhecimentos especializados mas atrai muita atenção do público. Ex.: Política de cotas, descriminalização do aborto e drogas, etc.

Política de alta complexidade técnica, mas com pouca visibilidade. Ex.: Lei de eficiência energética, Política cambial, etc.

Políticas de baixa complexidade técnica e de pouca atenção popular. Ex * Regulamentos internos, normas administrativas.

Produzir o mínimo de desigualdades. de renda, desenvolvimento produtivo, etc. 


\begin{tabular}{|c|c|c|}
\hline \multirow[t]{4}{*}{ Autor: Teixeira (2002) } & CONJUNTURAIS & Intervenções tópicas orientadas para aliviar uma situação temporária. Ex.: bolsa família, etc. \\
\hline & UNIVERSAIS & Aquelas destinadas a todos os cidadãos. Ex.: SUS, etc. \\
\hline & SEGMENTAIS & $\begin{array}{l}\text { Aquelas que caracterizam um fator determinado, como idade, gênero e outros. Ex.: Estatuto do Idoso, } \\
\text { Estatuto da Criança e do Adolescente, etc. }\end{array}$ \\
\hline & FRAGMENTADAS & $\begin{array}{l}\text { Aquelas destinadas a grupos específicos dentro dos segmentos sociais. Ex.: Programa de erradicação } \\
\text { do trabalho infantil, etc. }\end{array}$ \\
\hline $\begin{array}{l}\text { Fundamentada na categorização de } \\
\text { apenas uma variável, polarizando a } \\
\text { análise para esse binômio. } \\
\text { Autor: Bozeman \& Pandey (2004) }\end{array}$ & $\begin{array}{l}\text { CONTEÚDO } \\
\text { TÉCNICO OU } \\
\text { POLITICO }\end{array}$ & $\begin{array}{l}\text { A diferenciação de conteúdo é um determinante da escolha dos atores e do nível de conflitos esperado } \\
\text { no processo decisório. }\end{array}$ \\
\hline
\end{tabular}

Fonte: Elaboração própria, a partir de Rua e Romanini [s.d.]. 


\subsection{Critérios de avaliação de Políticas Públicas}

No entender de Faria (2005) (apud TREVISAN e BELLEN (2008), parte significativa dos estudos sobre os processos de avaliação de políticas públicas desde a década de 1960 refere-se às questões de ordem metodológica e/ou às distintas maneiras de se classificar a avaliação.

Para Fagundes e Moura (2009), as abordagens mais tradicionais de avaliação de programas sociais ainda recorrem aos conceitos associados às etapas constitutivas do processo de planejamento, onde os objetivos, as metas, a população beneficiária e os recursos empregados são destacados como elementos centrais que estruturam e definem a abrangência de um programa social. Esses elementos proporcionariam as condições para o estabelecimento de um processo de avaliação objetivo e sistemático dos programas sociais.

Ainda para os autores, diversos estudos identificam que a partir da comparação dos objetivos, metas, população-alvo e recursos empregados com os custos, efeitos, impactos e resultados efetivamente verificados na implementação é possível estabelecer apreciações sobre a cobertura e as condições de eficiência, eficácia e efetividade dos programas sociais (FAGUNDES e MOURA, 2009).

Nessa direção, a avaliação de políticas consiste em um procedimento sistemático de levantamento e análise de dados, com o objetivo de atribuir valor às políticas públicas, por meio da identificação dos resultados, da análise crítica dos programas, de forma a verificar em que medida as metas estão sendo alcançadas, a que custo e quais os processos ou efeitos que estão sendo ativados, indicando novos cursos de ação mais eficazes quando em confronto com os objetivos estabelecidos na sua concepção ou formulação (FIGUEIREDO; FIGUEIREDO, 1986; PARSONS, 1996; HOLANDA, 2003; KNOEPFEL, 2007 apud CARDOSO, 2011).

Na visão de Flexor e Leite (2007, p. 11) “a avaliação é uma função que consiste em apreciar os efeitos atribuídos as ações do governo", sendo assim ela é uma atividade normativa. Os autores retratam sobre as divergências dos avaliadores quanto aos reais efeitos da ação pública, isso porque esses agem em função de suas percepções e de quadros de referências, com seus valores e normas, os quais não são compartilhados por todos. Outra dificuldade, refere-se ao fato de que os resultados efetivos são relativamente independentes das expectativas iniciais e, ainda, que os objetivos são geralmente ambíguos e causas externas podem vir a explicar os resultados, razão disso, as intenções 
podem mudar no decorrer do tempo, outros problemas podem surgir, ou seja, não existe causalidade unívoca (FLEXOR e LEITE, 2007).

Para Viana (1996), a avaliação deve se submeter a dois critérios: validez e confiabilidade. A validez indica se o que se mediu era o que se pretendia medir, já a confiabilidade refere-se às variações de tempo, indicador e leitura. A confiabilidade é razão inversa do erro, assim é possível haver confiabilidade, mas não validez, porém não há validez sem confiabilidade.

$\mathrm{Na}$ intenção de guiar a avaliação, são usados padrões de referências, assim classificados: absolutos - que considera as metas estabelecidas como padrão a ser alcançado; históricos - que compara os resultados ao longo do tempo; normativos - que compara o desempenho com programas similares; teóricos - baseado nos resultados planejados quando da elaboração do programa; negociados ou de compromisso - que se relaciona com algum procedimento específico para sua fixação, normalmente decorrente de consensos entre as partes envolvidas na gestão e os formuladores (COSTA E CASTANHAR, 2003 apud TREVISAN e BELLEN, 2008).

Siqueira (1990) propõe as seguintes dimensões para a avaliação:

a) dimensão analítica - capacidade de compreender as variáveis, tanto de natureza macrossocial quanto microssocial, que condicionam o desempenho da administração pública e o papel dos diferentes atores nesse processo.

b) dimensão instrumental - capacidade de ajudar a tomada de decisão frente a diferentes alternativas, de acompanhar o desempenho dos serviços públicos e de avaliar e divulgar seus resultados.

c) dimensão prescritiva - propor medidas de melhoria das ações governamentais, especialmente relacionadas à sua democratização crescente. Essas dimensões não são excludentes, mas complementares. 
Quadro 3 - Dimensões para avaliação de políticas.

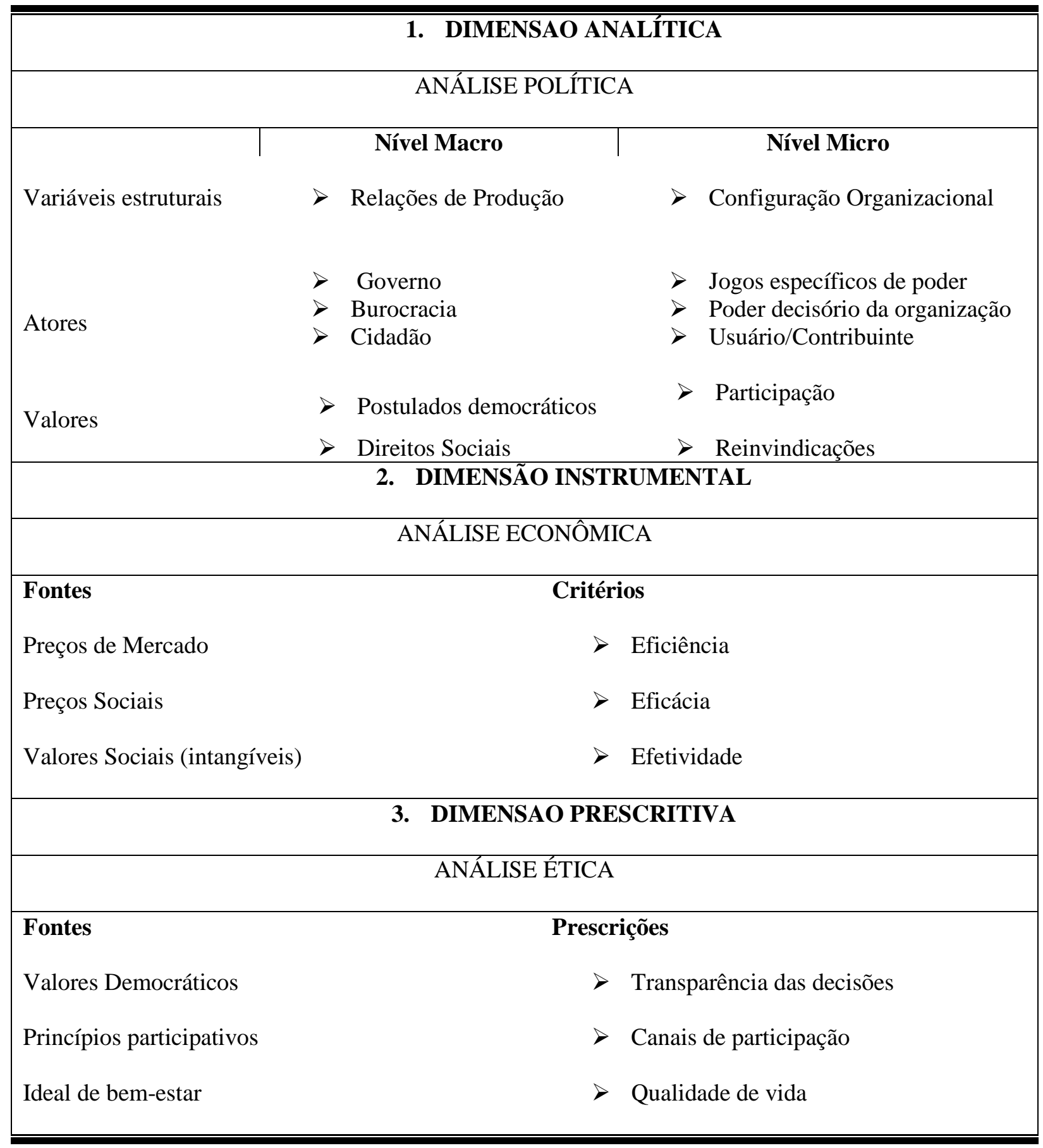

Fonte: Elaboração Siqueira (1990).

Ao tratar sobre a avaliação, Rolando Franco e Ernesto Cohen (1988) (apud VIANA, 1996) afirmam que esta etapa de análises de políticas públicas pode ser de quatro tipos: investigação, investigação avaliativa, avaliação e monitoramento, sendo que estes se diferenciam pelo momento em que são realizados (antes, durante ou depois da política); pelo objeto do estudo; pelos objetivos do estudo; pelas técnicas que empregam; e pela 
relação que estabelecem com a política. Viana (1996) estabelece as diferenças entre os tipos segundo esses critérios, como demonstrado no Quadro 4:

Quadro 4 - Diferenças entre os tipos de avaliação de políticas públicas segundo critérios de aplicação.

\begin{tabular}{|c|c|c|c|c|}
\hline Tipos & Investigação & $\begin{array}{c}\text { Investigação } \\
\text { Avaliativa }\end{array}$ & Avaliação & Monitoramento \\
\hline Momento & & Durante ou depois & Durante ou depois & Durante \\
\hline Objeto & - & $\begin{array}{l}\text { Aplicação de métodos de } \\
\text { investigação cientifica ou } \\
\text { empírica sobre avaliação. }\end{array}$ & $\begin{array}{l}\text { Averiguar e medir } \\
\text { quem se beneficiou, } \\
\text { em que medida, de que } \\
\text { modo, porquê. Avaliar } \\
\text { a adequação entre } \\
\text { meios e fins. }\end{array}$ & $\begin{array}{l}\text { Atividade } \\
\text { Gerencial }\end{array}$ \\
\hline Objetivo & $\begin{array}{l}\text { Básica: incremento de } \\
\text { conhecimento. } \\
\text { Aplicada: } \\
\text { conhecimento } \\
\text { para modificar a } \\
\text { racionalidade. }\end{array}$ & $\begin{array}{l}\text { Informações (Causais e } \\
\text { lógicas) sobre eficácia de } \\
\text { métodos. }\end{array}$ & $\begin{array}{l}\text { Informações sobre } \\
\text { operação e impacto. } \\
\text { Maximizar eficiência. } \\
\text { Aumento da } \\
\text { racionalidade. }\end{array}$ & $\begin{array}{l}\text { Controle de: } \\
\text { Entrega de insumos } \\
\text { Calendário de trabalho } \\
\text { Entrega dos produtos de } \\
\text { acordo com as metas }\end{array}$ \\
\hline Técnicas & - & - & $\begin{array}{lll}\text { Próprias: } & & \text { custos } \\
\text { benefícios e } & \text { custo } \\
\text { efetividade. } & & \end{array}$ & - \\
\hline $\begin{array}{c}\text { Relação com } \\
\text { a politica }\end{array}$ & Própria & Própria & Própria & Própria \\
\hline
\end{tabular}

Fonte: Elaboração Viana (1996).

Conforme Serafim e Dias (2012), a avaliação é um processo técnico que permite o desenvolvimento de padrões para a revisão e medição sistemática do estado do problema, sendo que, como resultados da avaliação, três situações podem ocorrer: 1. Auxiliar na melhoria da Política, e consequentemente, na sua continuidade; 2. Finalizar a política existente e; 3. Desenvolver uma nova política. É também compreensão dos autores ser a avaliação uma ferramenta política, pois permite a prestação de contas para a sociedade, o que favorece a confiança e legitimidade do sistema.

Cardoso (2011), cita autores como Cohen e Franco (1994) para configurar as avaliações políticas em avaliação ex-ante, avaliação ex-post ou somativa - avaliação formativa ou de processo, e avaliação de monitoramento. 
Na síntese de Cardoso (2011), para a avaliação ex-ante, que é realizada antes do início do projeto, é analisada a viabilidade da implementação da política quanto a sua relação custo-benefício. De forma complementar Lobo (1998) (apud TREVISAN e BELLEN (2008) esclarece ser a avaliação ex ante consistida também das análises de custo-efetividade e das taxas de retorno econômico dos investimentos previstos. A avaliação intermediária ocorre durante a implementação do programa e tem como objetivo dar o suporte e melhoria da gestão do programa. As avaliações posteriores à etapa de implementação, inclusive, do programa são chamadas de ex post.

Viana (1996) afirma ser o estudo de avaliação do tipo específico, onde estão compreendidas a investigação avaliativa e a avaliação propriamente dita, sendo que a avaliação propriamente dita abrange a dois tipos de estudos: a avaliação de processo e a de impacto - que se distinguem pela natureza, modelo de avaliação, tamanho, métodos e lógica de avaliação e, ainda ao objeto e objetivo. Ambas são avaliações ex post, ou seja, ocorrem durante e depois da fase de implementação das políticas. A avaliação de processo estuda a fase de implementação de determinada política, a avaliação de impacto estuda o efeito dos resultados de uma política.

Nessa perspectiva, a avaliação de processo se preocupa, basicamente, em diagnosticar as possíveis falhas de um programa, no que diz respeito aos instrumentos, procedimentos, conteúdos e métodos, adequação ao público-alvo, visando o seu aperfeiçoamento, por meio da interferência direcionada para seus aspectos intrínsecos (CAVALCANTI, 2008 apud CARDOSO, 2011). Segundo Viana (1996), essa finalidade da avaliação oportuniza aos escalões envolvidos na política as seguintes vantagens: para os superiores - a avaliação permite uma alocação melhor dos recursos; para os administradores - a otimização da relação insumo/produto; e para os técnicos - um maior conhecimento dos aspectos operativos que envolvem a política.

A avaliação de impactos diz respeito aos efeitos do programa sobre o públicoalvo, e tem a intenção de estabelecer uma relação de causalidade entre a política e as alterações nas condições sociais (FIGUEIREDO; FIGUEIREDO, 1986 apud CARDOSO,2011). Em sua análise, Viana (1996) afirma que a avaliação tem como objetivo determinar se houve modificação e a magnitude dessa modificação; quais segmentos afetou e em que medida; e quais foram as contribuições dos distintos componentes da política na realização de seus objetivos.

Segundo a UNEP (2009) (apud SILVA, 2015), os processos de avaliação de políticas precisam ser implementados desde a concepção da política, pois assim é possível 
avaliar o progresso e efetuar modificações quando necessário. Além disso, a probabilidade de sucesso de uma política diminui quanto mais difícil for avaliá-la e fazer cumprir as medidas estipuladas.

O Quadro 5 elaborado por Silva (2015), demonstra as definições teóricas de critérios de avaliação comuns encontrados na literatura de políticas públicas, por entendermos ter o mesmo, ainda que na perspectiva da análise realizada pela autora para a sua pesquisa, oferecido um detalhamento mais abrangente sobre os critérios de avaliação e suas definições.

Quadro 5 - Critérios de avaliação aplicados às Políticas Públicas.

\begin{tabular}{|c|c|}
\hline Critérios de Avaliação & Definição \\
\hline Equidade & $\begin{array}{l}\text { Visa responder questões sociais como: quais os efeitos positivos ou negativos sobre a } \\
\text { pobreza, emprego, comércio, crescimento, taxa de inovação que podem ser atribuídos à } \\
\text { política avaliada e se os impactos negativos são permanentes ou transitórios (OECD, } 1997 \\
\text { apud UNEP, 2009). Além disso, quais grupos sociais estão sendo beneficiados e quais } \\
\text { estão arcando com os custos da política ou instrumento avaliado (BAUMOL e OATES, } \\
\text { 1979). }\end{array}$ \\
\hline Eficiência & $\begin{array}{l}\text { Analisa a política ou instrumento do ponto de vista econômico. Para que a política seja } \\
\text { socialmente eficiente, não deverá necessariamente ser eficiente em custos, mas equilibrar } \\
\text { custos e benefícios, ao tentar minimizar custos e alcançar um benefício maior (BAUMOL } \\
\text { e OATES, 1979; FIELD, 1997). }\end{array}$ \\
\hline Eficácia & $\begin{array}{l}\text { Capacidade do instrumento ou política em alcançar o objetivo ou meta estabelecida. Uma } \\
\text { política ou instrumento é mais eficaz do que outro se permitir um maior grau de certeza } \\
\text { de que seus objetivos serão atingidos. }\end{array}$ \\
\hline $\begin{array}{l}\text { Incentivo ao esforço } \\
\text { máximo ou motivação }\end{array}$ & $\begin{array}{l}\text { Visa quantificar os incentivos oferecidos que levam à superação dos objetivos } \\
\text { estabelecidos pelas políticas públicas, levando empresas e indivíduos a buscar formas e } \\
\text { comportamento inovadores e melhoria contínua da redução do nível de degradação } \\
\text { (FIELD, 1997). }\end{array}$ \\
\hline Custo administrativo & $\begin{array}{l}\text { Refere-se aos custos dos recursos necessários para administrar o instrumento ou } \\
\text { implementar a política, sejam eles os custos operacionais, regulatórios, de monitoramento } \\
\text { e de fiscalização. As políticas, programas e projetos aprovados precisam de um } \\
\text { planejamento inicial que garanta o financiamento dos recursos necessários. Mesmo as } \\
\text { previsões de instrumentos econômicos que forneçam fundos por meio de tributos } \\
\text { precisarão de um financiamento inicial para estabelecer o programa ou projeto (UNEP, } \\
\text { 2009). }\end{array}$ \\
\hline
\end{tabular}




\begin{tabular}{|c|c|}
\hline Aceitação Política & $\begin{array}{l}\text { Refere-se à receptividade da aplicação de instrumentos e políticas por segmentos sociais, } \\
\text { empresas e políticos (BAUMOL e OATES, 1979). A aceitação pública é essencial para } \\
\text { garantir a execução da política. Os grupos de interesse e empresas do setor ou que sejam } \\
\text { impactados pelas políticas possuem um papel fundamental nas discussões, pois são a partir } \\
\text { desses grupos que os instrumentos de política irão agir e sua eficácia dependerá da } \\
\text { aceitação pública de sua aplicação. As inter-relações setoriais também podem contribuir } \\
\text { para a aceitação de uma política, pois os benefícios de um programa ou política podem } \\
\text { influenciar ou competir com outros setores e Ministérios e prioridades governamentais } \\
\text { (UNEP, 2009). }\end{array}$ \\
\hline Permanência & $\begin{array}{l}\text { Para a permanência de uma política ela precisa ser realista, as mudanças de } \\
\text { comportamento dos agentes precisam permanecer mesmo com a retirada dos seus } \\
\text { estímulos e que isso não provoque uma regressão ao comportamento anterior (BAUMOL } \\
\text { e OATES, 1979). }\end{array}$ \\
\hline
\end{tabular}

Fonte: Silva (2015), a partir de BAUMOL e OATES, 1979; FIELD, 1997; OECD, 1997 apud UNEP, 2009; UNEP, 2009.

Como visto anteriormente, para as políticas públicas são adotados diferentes critérios para o processo avaliativo, sendo que a literatura costuma, mais comumente, distingui-la em termos de eficácia, eficiência e efetividade, que são recursos analíticos destinados a separar aspectos distintos dos objetivos, da abordagem e dos métodos e técnicas de avaliação (ARRETCHE, 1998 apud TREVISAN E BELLEN, 2008).

A relevância na adoção desses critérios, como mesmo afirmado por Antico e Jannuzzi (2006, p. 19) (apud SANO E MONTENEGRO FILHO, 2013), coadunam com a compreensão de que "a avaliação de um programa público requer indicadores que possam dimensionar o grau de cumprimento dos objetivos dos mesmos (Eficácia), o nível de utilização de recursos frente aos custos em disponibilizá-los (Eficiência) e a Efetividade social, a capacidade de atingir as metas propostas".

Para Figueiredo e Figueiredo (1986, p. 113) o conceito de Eficiência mais usualmente utilizado em estudos econômicos é o de "custo mínimo possível para o máximo de benefício". Ainda para o autor quando da aplicação do conceito de eficiência como critério de avaliação de políticas, especialmente as sociais, essa definição ganha nova dimensão ao agregar, ao lado da noção econômica de custo -benefício, a noção de custo e benefícios políticos.

Assim, na análise do autor, o conceito de eficiência na esfera pública é bidimensional, pois se vê, por um lado, a eficiência instrumental, que se define pela relação exata entre custos econômicos e benefícios - em geral, tangíveis e divisíveis e, de 
outro lado, tem-se a eficiência política, definida pela relação entre os "custos" sociais ou políticos, e os benefícios deles decorrentes. (FIGUEIREDO e FIGUEIREDO, 1986).

Silva (2015) ao avaliar sobre esse ponto de vista econômico, a partir das concepções de Baumol e Oates, 1979; Field, 1997, afirma que uma política socialmente eficiente não necessariamente deverá ser eficiente em custos, seu objetivo deverá ser o de manter o equilíbrio entre os custos e benefícios na tentativa de minimizar os custos e alcançar um benefício maior.

Segundo Maia et al. (2005), o enfoque avaliativo, ex-ante, que utiliza os conceitos de eficiência quando da elaboração de um projeto, sob a ótica governamental, contempla os estudos de viabilidade considerando: 1) a viabilidade financeira; 2) a viabilidade econômica (maximização do bem-estar econômico e; 3) a viabilidade social, que contempla o valor subjetivo dos diversos seguimentos da população beneficiada, sendo esse valor associado ao mérito e ao princípio da equidade distributiva dos benefícios e custos dos bens públicos e quase públicos.

A avaliação de efetividade está relacionada aos impactos diretos e indiretos dos serviços oferecidos pelas políticas.

Segundo Figueiredo e Figueiredo (1986), a avaliação da efetividade deve demonstrar as relações de causalidade existentes entre a realidade social e uma política em particular, o que representa uma questão metodológica muito complexa, uma vez que se deve demonstrar que os resultados estão vinculados aos produtos oferecidos pelas políticas públicas estudadas.

Em decorrência da natureza do impacto pretendido, a efetividade pode ser: 1 . Objetiva; critério de aferição da mudança quantitativa entre o antes e o depois da execução do programa; 2. Subjetiva, critério de aferição de mudanças psicológicas e de mudanças nos sistemas de crenças e valores. Tem também a função de aferir a percepção da população sobre a adequação dos resultados objetivos do programa aos seus desejos, aspirações e demandas. 3. Substantiva: critério de aferição de mudanças qualitativas nas condições sociais de vida da população alvo do Programa (FIGUEIREDO e FIGUEIREDO, 1986).

Considerando que a abordagem de avaliação aplicada em nossa pesquisa foi a da eficácia, decidimos por realizar uma contextualização mais específica para os seus conceitos e aspectos metodológicos de aplicação. 


\subsubsection{Metodologias para avaliação da eficácia de Programas}

A noção de eficácia se refere ao "grau em que se alcançam os objetivos e metas de um programa ou projeto na população beneficiária, em um determinado período de tempo, independentemente dos custos implicados" (COHEN e FRANCO, 1993: 102 apud COTTA, 1998).

Para Fagundes e Moura (2009), a avaliação de eficácia compreende não apenas aferir os efeitos diretos de alcance das metas propostas por um programa ou política, como, por exemplo, medir quantitativamente o número de beneficiários atingidos, mas também aferir seus efeitos indiretos, sejam eles relacionados à intencionalidade da ação, sejam eles os efeitos perversos, que são, imediatamente, contraditórios em relação ao intento da ação.

Ainda para os autores, em uma avaliação de eficácia, a compreensão desses aspectos deve estar sempre presente, para que não se analise a intervenção em si, esquecendo suas determinações. Não é somente a intervenção programada, nem o cotidiano previsto e conhecido que irão determinar o desenvolvimento e os resultados da ação, existem eventos não previstos que influenciam substancialmente os resultados de uma ação programada, isso em diferentes níveis (FAGUNDES e MOURA, 2009).

A avaliação de eficácia pressupõe a comparação de objetivos com resultados. Assim, a eficácia é uma medida do quanto se atingiu um objetivo proposto ou até que ponto foi obtido um nível de desempenho considerado satisfatório. A medida de eficácia está relacionada com a maximização de resultados a custos satisfatórios, não necessariamente os mínimos. (FERNANDES, 1991).

Figueiredo e Figueiredo (1986, p.110) afirmam que a "avaliação de processos visa a aferição da eficácia”, se as diretrizes concebidas para os programas foram ou estão sendo realizadas e se o seu produto atingiu ou atingirá as metas programadas. Os autores destacam a importância dessa linha de avaliação pelo fato que durante a realização de um programa é impossível se antever os problemas e conflitos que poderão ocorrer. Mesmo que a análise de experiências passadas ajude no processo de conhecimento ela jamais será suficiente para descartar a avaliação processual concomitante, a qual permite controlar, com a devida antecipação, o tamanho e a qualidade do efeito esperado.

A metodologia para a avaliação da eficácia pode ser realizada pela estratégia da eficácia objetiva, ou avaliação de metas. Ela é executada pelos órgãos gerenciadores do programa e expressa por meio de relatórios anuais. A sua aplicação ocorre no sentido de verificar se as metas atingidas estão dentro dos limites toleráveis, sendo que são esses 
limites que estabelecem as faixas de sucesso ou de fracasso do programa (FIGUEIREDO e FIGUEIREDO, 1986).

Neste contexto, a mensuração da eficácia se dá por meio dos Indicadores de eficácia, os quais foram estabelecidos para o cumprimento das metas do Programa. A avaliação desses indicadores se refere ao estudo da verificação dos objetivos e instrumentos explícitos dos programas a serem analisados e seus resultados efetivos. Nesta avaliação podem ser verificados as metas e os instrumentos propostos e os efetivamente atingidos ou empregados (FIGUEIREDO e FIGUEIREDO, 1986).

Sobre esses indicadores de eficácia, é consenso entre estudiosos de que todo monitoramento e avaliação baseiam-se neles e que estes auxiliam na tomada de decisão, de forma a permitir um melhor desempenho, a formulação de um orçamento mais racional e uma prestação de contas mais clara e objetiva (LEMOS, 2009 apud, SANO e MONTENEGRO FILHO, 2013).

A partir de análises de seus estudos, Jannuzzi e Patarra (2006) apud Sano e Montenegro Filho (2013), ensinam que o processo de construção de um sistema de indicadores sociais inicia-se com a determinação do objetivo do programa. Um segundo momento refere-se ao processo de delineação das ações que serão necessárias à sua realização para, em um terceiro momento, se escolher os dados e estatísticas que possam acompanhar cada uma dessas ações, informando a eficiência no uso dos recursos, a eficácia no cumprimento das metas e a efetividade das mudanças. Ainda para esses autores, a etapa de formulação dos programas deve prever a organização de procedimentos de coleta e de tratamento de informações específicas e confiáveis em todas as fases do ciclo de implementação, que possam permitir a construção dos indicadores de monitoramento desejados.

No caso em particular da eficácia, que estaria vinculada aos objetivos finais dos programas públicos, essa se expressa pela categoria de indicadores-resultado, os quais são requeridos na última etapa do ciclo, que se inicia com o diagnóstico, passa pela formulação e efetivação, findando com a avaliação. Suas propriedades permitem a identificação de boas práticas e déficits sociais, sendo as pesquisas amostrais e os registros administrativos sua fonte de dados predominante (JANUZZI e PATARRA, 2006 apud SANO E MONTENEGRO FILHO, 2013).

Conforme Figueiredo e Figueiredo (1986), outra estratégia é a avaliação dos meios, configurada como uma avaliação moral ou instrumental do Programa. Em 
pesquisas com esse objetivo tem-se três critérios: a eficácia funcional, a administrativa e a contábil.

A avaliação funcional, se aplica para o caso da intenção instrumental, cujos modelos analíticos são elaborados para aferir se os meios e a metodologia de implantação do programa estão sendo aplicadas conforme as estratégias anteriormente definidas, sendo que esse monitoramento pode ir além de uma simples constatação e, de forma experimental, simular a adequação entre os meios e fins propostos, considerando as condições organizacionais e sociais onde o programa está sendo implementado (FIGUEIREDO e FIGUEIREDO, 1986).

Ainda para os autores, os critérios da eficácia administrativa e contábil são aplicados quando a intenção da avaliação se estabelece na moralidade executória e que nesses casos os modelos analíticos de aferição são os de auditoria. Os critérios da eficácia administrativas e contábil não são instrumentos exclusivos de aferição da moralidade executória, eles também podem ser aplicados simultaneamente à avaliação funcional, de forma a inibir práticas administrativas e contábeis prejudiciais ao desempenho do programa. 


\section{ESTUDO DE CASO: UNB IDIOMAS E SUA EFICÁCIA}

As avaliações das particularidades que envolvem os Programas/Projetos extensionistas, seus objetivos, sua abrangência e os resultados da sua atuação são importantes para se verificar o cumprimento dos compromissos com a política extensionista e, ainda, possibilitar que as suas atividades sejam esclarecidas à comunidade, possibilitando a troca e a ampliação das suas ações.

Nos documentos avaliados sobre o Programa Permanente de Extensão UnB Idiomas (PPE UnB Idiomas), percebemos que as avaliações podem estar sendo realizadas desde uma concepção pragmática, mais como instrumento que justifica ações, ou para gerar relatórios de prestação de contas, do que como processo reflexivo, crítico, formativo e emancipador da política extensionista a que se pretende.

Desta forma, procuramos em nosso estudo avaliar a eficácia do UnB Idiomas, em razão do pouco conhecimento que se tem do Programa em termos de sua especificidade como política extensionista.

\subsection{O Programa Permanente de Extensão UnB Idiomas (UnB Idiomas)}

O UnB Idiomas foi criado, no ano de 2008, pelo Departamento de Línguas Estrangeiras e Tradução (LET), do Instituto de Letras (IL), da UnB, com o objetivo de reorganizar, em um Programa extensionista, as atividades dos cursos de idiomas promovidos pela então Escola de Línguas da UnB, extinta naquele mesmo ano.

Para a implementação das suas atividades foi elaborado, por Comissão de professores do LET, o seu Regimento Interno, sendo este posteriormente aprovado pelas instâncias do Colegiado do Departamento, pelo Conselho da Unidade, no caso o IL e, finalmente, pela CEX/DEX em sua $448^{a}$ reunião, realizada em 25/09/2008.

Posteriormente, no ano de 2014 o Regimento (APÊNDICE B) é atualizado, de forma a contemplar as adaptações necessárias em razão do incremento das atividades extensionista e de novas organizações administrativas do Programa.

Conforme estabelecido em seu Regimento, o UnB Idiomas tem como finalidade essencial "atender à crescente demanda das comunidades interna e externa da UnB e de organizações públicas elou privadas relacionada ao aprendizado de línguas estrangeiras".

A organização e desenvolvimento das suas atividades são norteadas pelos seguintes objetivos:

I. Estimular, apoiar e incentivar o aprendizado de idiomas; 
II. Desenvolver sensibilidade intercultural, por meio do ensino de idiomas;

III. Proporcionar aos profissionais da área de Letras programas e eventos de formação continuada e atualização;

IV. Auxiliar na realização de programas de educação para professores, com o enfoque na pesquisa em sala de aula;

V. Revisar e desenvolver novas metodologias para o ensino de línguas, bem como discutir e sistematizar os procedimentos metodológicos utilizados na própria prática do PPEUnBIdiomas;

VI. Elaborar e aperfeiçoar material didático a ser utilizado em sala de aula;

VII. Fornecer oportunidade diferenciada para que os estudantes de licenciaturas do LET/IL possam desenvolver suas atividades de estágio curricular obrigatório.

Para a administração maior do UnB Idiomas foi criado o Conselho Deliberativo, estabelecido no regimento do Programa como órgão normativo, consultivo e deliberativo que tem como atribuição elaborar, propor e aprovar estratégias e políticas globais para o Programa.

Os objetivos estabelecidos para o Programa foram concebidos na intenção de que fossem proporcionadas as condições para o desenvolvimento de novas metodologias e técnicas de ensino/aprendizagem de línguas estrangeiras, tanto a partir das práticas desenvolvidas no âmbito das disciplinas da graduação - Estágio Supervisionado 1 e 2, dos Cursos de licenciaturas plenas em Língua Inglesa, Língua Francesa, Espanhol e Japonês, como também àquelas decorrentes dos estudos e pesquisas realizados no âmbito dos Programas de Pós-graduação do LET, em especial o Programa de Pós-graduação em Linguística Aplicada (PGLA).

Ademais, os espaços didáticos oportunizados pelos cursos de idiomas oferecem excelente campo de estudos, seja para a elaboração de novas prática metodológicas de ensino, seja para aquelas destinadas à formulação ou avaliação de material didático específico para o ensino de idiomas como língua estrangeira.

Outro de seus objetivos é o de estimular o aprendizado de línguas estrangeiras no âmbito da comunidade universitária e comunidade externa à UnB.

Desde essas orientações acadêmicas foram organizadas 3 (três) grandes áreas de atuações para o funcionamento do Programa, as quais são desenvolvidas sob a concepção de Projetos, são eles: a) Projeto de Cursos de idiomas do estágio supervisionado; b) Projeto de Cursos abertos sequenciais de idiomas; e c) Projeto de Cursos 
corporativos de idiomas, que têm organização e abrangência distintas, como demonstrado na Figura 2.

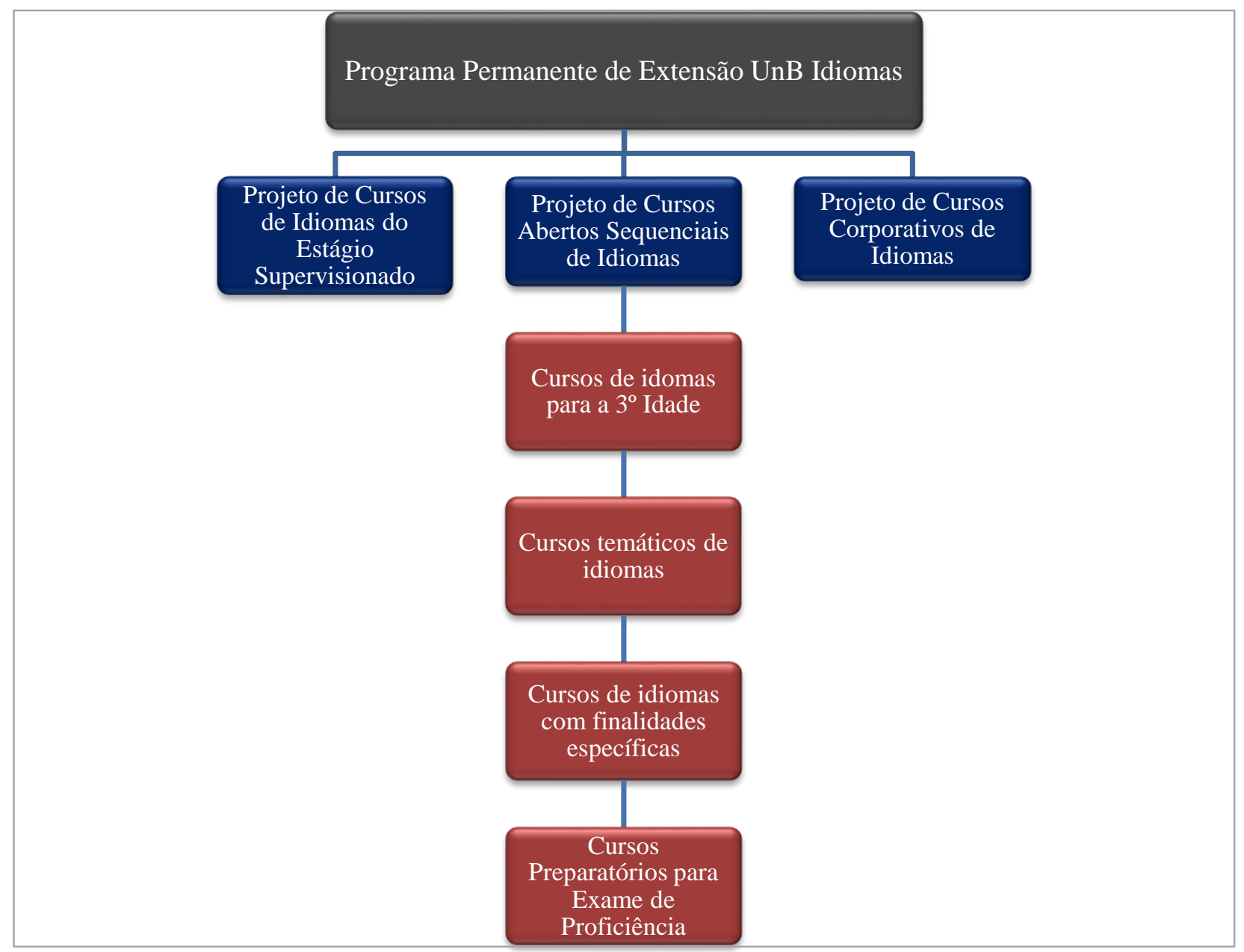

Figura 2: Organização do Programa Permanente de Extensão UnB Idiomas

Fonte: elaboração própria.

\subsubsection{Projeto de Cursos de idiomas do estágio supervisionado}

Projeto que contempla atividades voltadas para a elaboração e implementação de cursos gratuitos de línguas estrangeiras, em níveis iniciais dos idiomas Espanhol, Francês, Inglês e Japonês.

Por meio da realização desses cursos são oferecidos os meios para a prática do estágio obrigatório para os estudantes dos últimos anos dos Cursos de graduação Licenciatura Plena de Língua Inglesa, Língua Francesa, Espanhol e Japonês, matriculados nas disciplinas "Estágio Supervisionado 1 e 2", os quais atuam como instrutores dos referidos cursos/níveis sob a supervisão e orientação dos docentes do LET responsáveis pelas referidas disciplinas e também pela elaboração e coordenação dos cursos/níveis. 


\subsubsection{Projeto de Cursos abertos sequenciais de idiomas}

Projeto com atividades voltadas para a realização de cursos de línguas estrangeiras destinados à comunidade: a) interna: estudantes, professores e funcionários da UnB e; externa: comunidade do Distrito Federal, e que se realizam por meio de matrículas específicas e mediante o pagamento de taxas de inscrição.

No âmbito do Projeto de Cursos abertos sequenciais de idiomas são oferecidos, ainda, cursos de línguas estrangeiras com métodos e objetivos próprios, desenvolvidos por docentes e estudantes da pós-graduação do LET como resultado do aprofundamento de suas pesquisas, e que oferecem novas abordagens pedagógicas para o aprendizado de idiomas como línguas estrangeiras, tais como: Cursos de idiomas para a terceira idade; Cursos de idiomas com finalidades específicas; Cursos de idiomas preparatórios para Exame de Proficiência e Cursos temáticos de idiomas.

Cursos de idiomas para a terceira idade: metodologia de ensino que privilegia a visão da língua como instrumento de inclusão, de interação lúdica e significativa, tendo como foco do trabalho em sala de aula a construção de práticas que favoreçam e estimulem as trocas entre os indivíduos de modo a garantir-lhes papel ativo nas situações do dia a dia ao tempo em que são promovidas a interação oral e escrita do idioma estrangeiro estudado.

Cursos de idiomas com finalidade específica: elaborados para atender necessidades específicas de estudo do idioma. São focados quase sempre em uma habilidade linguística (oral ou escrita).

Cursos de idiomas preparatórios para Exames de Proficiência: preparação dos aprendizes por meio do desenvolvimento das habilidades linguísticas (ler, falar, ouvir e escrever) específicas para exames de proficiência dos idiomas Inglês, Francês e Espanhol.

Cursos temáticos de idiomas: Cursos elaborados com modelo exclusivo desenvolvido pela pós-graduação do LET e que se destinam a aprendizes que querem estudar o idioma estrangeiro de forma prática e divertida, a partir de temas como o cinema, a culinária, a cultura, a história, dos países ao qual se refere o idioma. Os cursos promovem um aprendizado mais dinâmico sem focar no estudo da gramatica e sim na comunicação oral.

\subsubsection{Projeto de Cursos corporativos de idiomas}

Projeto com atuação voltada para a realização de Cursos de línguas estrangeiras, com métodos de ensino próprio para o atendimento de grupos corporativos, e que se 
realizam por meio de contratos específicos firmados por instituições públicas e privadas com a FUB/UnB.

Os cursos são elaborados por docentes do LET, que também atuam como Coordenadores dos cursos junto ao Interfoco/DEX, e por profissionais da área de Letras, que atuam na supervisão dos cursos desde as orientações dos Coordenadores, sob a perspectiva de atendimento às diversas solicitações de organismos públicos e privados. Para o seu desenvolvimento são adotadas estratégias diferenciadas, voltadas ao atendimento das especificidades dos órgãos contratantes e que se estruturam com abordagens didáticas na forma de cursos de idiomas para comunicação geral.

As aulas acontecem nas instalações dos órgãos contratantes, seja em Brasília ou nas outras unidades federadas onde são realizados os cursos. A equipe de professores que atua nos cursos é composta por docentes do LET e por profissionais com formação acadêmica na área de Letras, que desenvolvem suas atividades sob a supervisão acadêmica do Coordenador responsável pelo Curso, docente do LET, e sob as normas e orientações do Programa e das normas de extensão da UnB.

\subsubsection{UnB Idiomas - entendendo sua origem e operacionalização}

Em documentação analisada do Programa para fins dessa pesquisa, há o registro de que, com a absorção das atividades realizadas pela extinta Escola de Línguas da UnB, que comportava uma demanda anual de 800 alunos distribuídos em três idiomas, foi identificado pela equipe administrativa do UnB Idiomas uma série de problemas na operacionalização das inscrições dos alunos e na gestão dos recursos financeiros então arrecadados, isto em razão de que todo o processo até então utilizado, desde o pagamento dos valores por alunos e efetivação e acompanhamento das matrículas dos interessados, era realizado por meio de intervenção manual, comprometendo as atividades de gestão administrativa, expondo-a a erros e riscos. Além disso, o atendimento à comunidade era precário e a simples ideia de expansão do Programa com aquele modelo gerencial era inviável.

Assim, ainda no de 2009, o UnB Idiomas iniciou um processo de organização interna que definiu, em linhas gerais, um novo patamar para a captação e gerenciamento dos recursos decorrência das suas atividades extensionistas, promovendo, para isto, a modernização da operacionalização dos sistemas de gerenciamento interno para as atividades acadêmica, administrativa e financeira, o qual teve início com a criação do sistema para informatização de dados, o Sistema de Gestão Integrada (SGI). 
Com o seu sistema de gerenciamento de dados e uma gestão acadêmica e administrativa própria do LET, o programa passou a desenvolver estratégias para ampliação do atendimento à comunidade universitária e expansão para o público do Distrito Federal. Novos horários foram criados baseados no estudo de disponibilidade do público alvo, aumentando a oferta de vagas nos cursos promovidos pelos Projetos.

A Figura 3 apresenta a linha do tempo das atividades do UnB Idiomas.

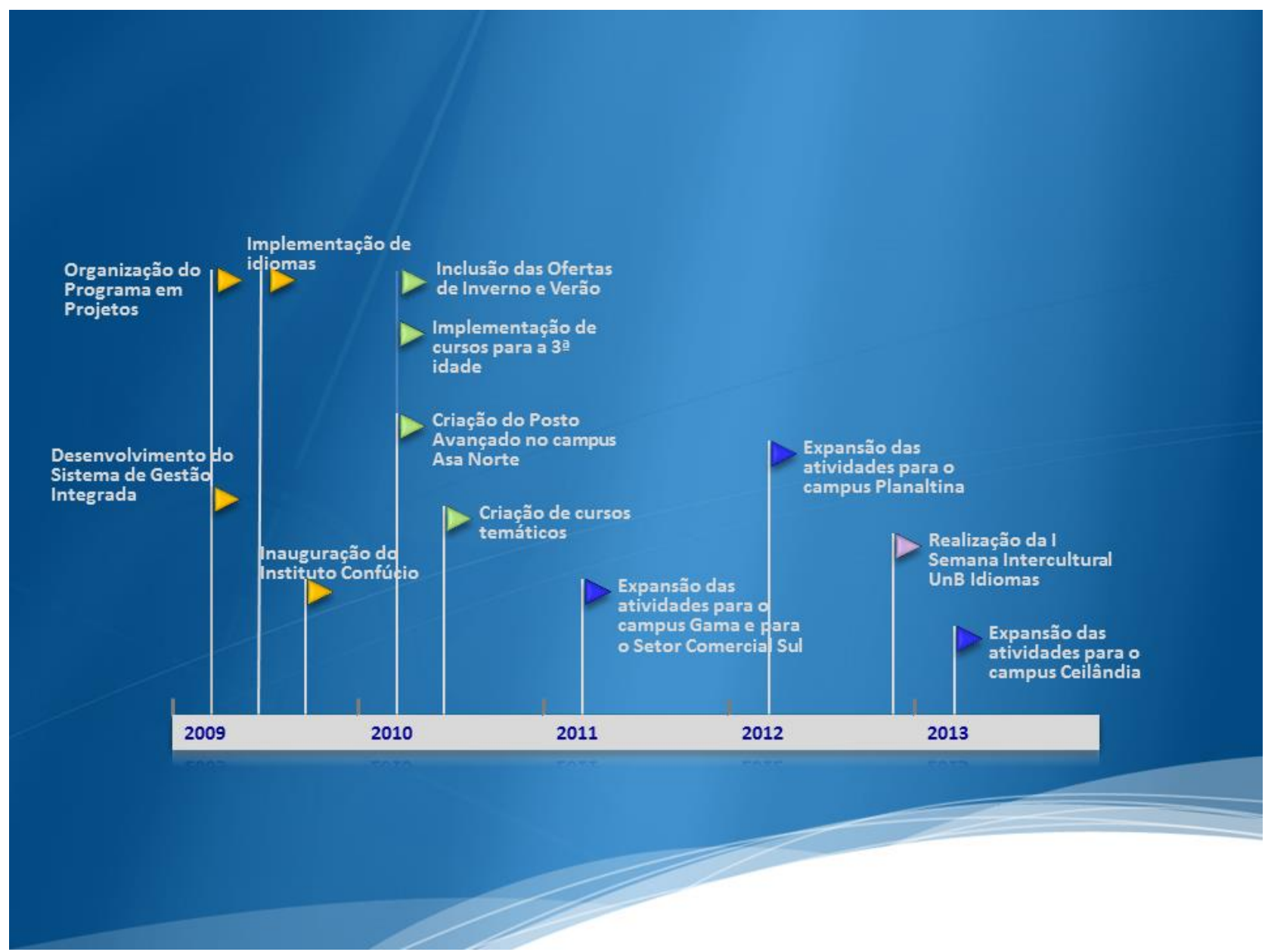

Figura 3: Linha do tempo das atividades do UnB Idiomas

Fonte: elaboração própria.

A divulgação das atividades de cursos e eventos culturais promovidos pelo UnB Idiomas no âmbito dos seus projetos, são realizadas por meio da sua página eletrônica, e pelos meios usuais utilizados pela Assessoria de Comunicação da UnB.

Do total dos recursos arrecadados com: a) taxas de matrículas provenientes dos cursos constantes do Projeto de Cursos abertos sequenciais de idiomas e; b) faturamento decorrentes dos Contratos realizados no âmbito do Projeto de Cursos corporativos de idiomas, é recolhido à conta da Universidade de Brasília o percentual de $10 \%$ sobre o 
valor total dos recursos, à título de custos indiretos. O Programa ainda destina, também a partir dos ingressos financeiros dos Projetos acima, recursos para o LET, na ordem de $10 \%$ dos valores arrecadados, os quais são destinados para o apoio à realização de eventos acadêmicos, participação de docentes do LET em eventos científicos nacionais e internacionais e, ainda, para a aquisição de equipamentos para as atividades regulares da graduação e pós-graduação.

O Programa dispõe de um quadro de colaboradores que atuam nas atividades acadêmicas e administrativas do Programa e de seus Projetos, sendo este formado por docentes e funcionários da UnB, e por prestadores de serviços, os quais atuam diretamente nas atividades dos Projetos. Na intenção de esclarecer sobre os atores que participam das atividades do Programa, apresentamos no Quadro 6 a denominação da função dada a esses atores e a sua atuação no Programa:

Quadro 6 - Atores participantes das atividades do UnB Idiomas e sua atuação.

\begin{tabular}{|c|c|}
\hline Atores & Atuação \\
\hline Chefe do LET & Presidente do Conselho do UnB Idiomas \\
\hline Coordenadora Geral & $\begin{array}{l}\text { Docente do LET, responsável pela gestão acadêmica do } \\
\text { Programa, integra o Conselho do UnB Idiomas. }\end{array}$ \\
\hline Coordenadora Administrativa & $\begin{array}{l}\text { Profissional responsável pela gerência administrativa e } \\
\text { financeira do Programa, integra o Conselho do UnB Idiomas. }\end{array}$ \\
\hline Coordenadores de áreas & $\begin{array}{l}\text { Docentes do LET, responsáveis pela Coordenação dos Cursos } \\
\text { da área de sua competência linguística (Espanhol, Francês, } \\
\text { Inglês, Japonês e de outros idiomas) - atuam diretamente nos: } \\
\text { a) Projeto de Curso de Idiomas do Estágio Supervisionado e b) } \\
\text { Projeto de Cursos Abertos Sequenciais de Idiomas. Integram o } \\
\text { Conselho do UnB Idiomas. }\end{array}$ \\
\hline $\begin{array}{l}\text { Coordenador do Projeto de Cursos } \\
\text { corporativo de Idiomas }\end{array}$ & Docente do LET, integra o Conselho do UnB Idiomas. \\
\hline Colaboradores administrativos & $\begin{array}{l}\text { Funcionários da UnB e prestadores de serviços que atuam nas } \\
\text { atividades administrativas do Programa e seus Projetos. }\end{array}$ \\
\hline Supervisores de áreas & $\begin{array}{l}\text { Estudantes da pós-graduação e/ou profissionais da área de } \\
\text { Letras que atuam na supervisão dos cursos, da área de sua } \\
\text { competência linguística, no Projeto de Cursos Abertos } \\
\text { Sequenciais de Idiomas. }\end{array}$ \\
\hline $\begin{array}{lcr}\text { Professores } & \text { responsáveis } & \text { pelas } \\
\text { Disciplinas } & \text { do } & \text { Estagio } \\
\text { Supervisionado } & & \\
\end{array}$ & $\begin{array}{l}\text { Docentes do LET, Coordenadores de área do UnB Idiomas e } \\
\text { responsáveis pela Coordenação do Cursos do Projeto de Cursos } \\
\text { de Idiomas do Estagio Supervisionado. }\end{array}$ \\
\hline $\begin{array}{l}\text { Estudantes de Graduação } \\
\text { matriculados nas disciplinas - Estagio } \\
\text { Supervisionado } 1 \text { e } 2\end{array}$ & $\begin{array}{l}\text { Instrutores dos Cursos constantes do Projeto de Cursos de } \\
\text { Idiomas do Estagio Supervisionado, de acordo com o Curso de } \\
\text { Licenciatura a que estiver matriculado. Estes atores serão } \\
\text { denominados nesta pesquisa como Estudantes. }\end{array}$ \\
\hline Estudantes da Pós-graduação do LET & $\begin{array}{l}\text { Professores dos Cursos constantes do Projeto de Cursos } \\
\text { Abertos Sequenciais de Idiomas; formuladores de novos } \\
\text { modelos de cursos, junto com seus orientadores. }\end{array}$ \\
\hline Bolsistas & $\begin{array}{l}\text { Estudantes do grupo carente } 1 \text { e } 2 \text { indicados pelo Decanato de } \\
\text { Assuntos Comunitários e; professores e funcionários da UnB } \\
\text { selecionados pelo PROCAP. Categoria exclusiva de cursos }\end{array}$ \\
\hline
\end{tabular}




\begin{tabular}{|l|l|}
\hline \hline \multirow{3}{*}{ Professores } & $\begin{array}{l}\text { realizados no âmbito do Projeto de Cursos abertos sequenciais } \\
\text { de Idiomas. }\end{array}$ \\
\hline \multirow{2}{*}{ Alunos } & $\begin{array}{l}\text { Docentes do LET, alunos da pós-graduação e Profissionais } \\
\text { formados na área de Letras, que atuam como professores dos } \\
\text { cursos constantes do Projeto de Cursos Abertos Sequenciais de } \\
\text { Idiomas; e Projeto de Cursos Corporativos de Idiomas. }\end{array}$ \\
\hline \hline & $\begin{array}{l}\text { Aprendizes que realizam os cursos de idiomas oferecidos pelo } \\
\text { Programa. Estes atores serão denominados, para esta pesquisa, } \\
\text { como alunos aprendizes. }\end{array}$ \\
\hline
\end{tabular}

Fonte: elaboração própria a partir dos documentos do UnB Idiomas.

Considerando a dimensão da atuação do UnB Idiomas, foi recomendação da CEX/DEX da UnB, em sua 522 a reunião, ocorrida em 03/10/2013, que as atividades de cursos do Programa fossem consolidadas como atividade de "Programa de Ação Continua", por se tratarem de atividades de extensão regulares já consolidadas na Universidade e com estrutura operacional própria.

\subsubsection{Objetivos dos Projetos do UnB Idiomas}

Tendo sido apresentados acima o percurso histórico e informações relevantes do UnB Idiomas, declarados em seus documentos, apresentamos no Quadro 7 os objetivos traçados para os Projetos desenvolvidos pelo UnB Idiomas:

\section{Quadro 7 - Objetivos dos Projetos extensionistas do UnB Idiomas.}

\begin{tabular}{|c|c|}
\hline Projeto & 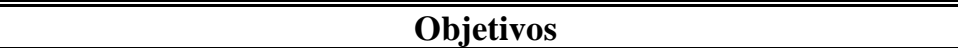 \\
\hline \multirow{5}{*}{$\begin{array}{l}\text { Projeto de Cursos de idiomas } \\
\text { do estágio supervisionado }\end{array}$} & $\begin{array}{l}\text { 1. Possibilitar a elaboração de Cursos de línguas estrangeiras, níveis } \\
\text { iniciais dos idiomas Espanhol, Francês, Inglês e Japonês, por } \\
\text { professores responsáveis pelas disciplinas da graduação - Estagio } \\
\text { Supervisionado/Cursos de Licenciatura Plena em Língua Inglesa, } \\
\text { Linha Francesa, Espanhol e Japonês. }\end{array}$ \\
\hline & $\begin{array}{l}\text { 2. oferecer as condições de organização para a realização desses } \\
\text { Cursos, em quantidade de turmas suficientes, de forma a permitir a } \\
\text { inclusão dos estudantes, matriculados nas disciplinas da graduação } \\
\text { Estágio Supervisionado, como instrutores dos Cursos, o que ocorre } \\
\text { sob a supervisão dos professores responsáveis pelas disciplinas de } \\
\text { Estágio Supervisionado, que também atuam como coordenadores } \\
\text { dos Cursos. }\end{array}$ \\
\hline & $\begin{array}{l}\text { 3. Disponibilizar, gratuitamente, os cursos/turmas para as } \\
\text { comunidades: a) interna: estudantes, professores e funcionários da } \\
\text { UnB e; b) externa: moradores do Distrito Federal e outras regiões. }\end{array}$ \\
\hline & $\begin{array}{l}\text { 4. Disponibilizar, gratuitamente, os cursos de Espanhol, níveis } \\
\text { iniciais, destinados ao público infanto-juvenil, para alunos das } \\
\text { últimas séries do ensino fundamental e alunos de nível médio da rede } \\
\text { pública de ensino - Cursos de Espanhol para o público Infanto } \\
\text { Juvenil - PESES 2. }\end{array}$ \\
\hline & $\begin{array}{l}\text { 5. Possibilitar os meios para a revisão e elaboração de material } \\
\text { didático exclusivos para os cursos. }\end{array}$ \\
\hline
\end{tabular}




\begin{tabular}{|c|c|}
\hline & $\begin{array}{l}\text { 6. Avaliar os cursos realizados a partir das orientações do Programa } \\
\text { e das normas de Extensão da Universidade. }\end{array}$ \\
\hline \multirow{12}{*}{$\begin{array}{l}\text { Projeto de Cursos abertos } \\
\text { sequenciais de idiomas }\end{array}$} & $\begin{array}{l}\text { 1. possibilitar a elaboração de cursos de Línguas Estrangeiras, a } \\
\text { partir de métodos exclusivos desenvolvidos por: a) acadêmicos do } \\
\text { LET e, b) estudantes da pós-graduação, decorrência dos } \\
\text { conhecimentos e práticas de ensino de idiomas e dos estudos e } \\
\text { pesquisas desenvolvidos no âmbito dos programas de pós-graduação } \\
\text { realizados pelo LET, e ainda, possibilitar a elaboração de cursos de } \\
\text { idiomas menos convencionais, a partir das relações de cooperação e } \\
\text { intercambio internacionais mantidas pelo LET. }\end{array}$ \\
\hline & $\begin{array}{l}\text { 2. possibilitar as condições para a implementação de cursos de } \\
\text { idiomas, elaborados pelos estudantes e professores que compõem os } \\
\text { Programas de pós-graduação do LET, de forma à promoção de novos } \\
\text { métodos de ensino/aprendizagem de idiomas. }\end{array}$ \\
\hline & $\begin{array}{l}\text { 3. implantar as atividades do Projeto, na medida do possível, em } \\
\text { todos os campi da Universidade, de forma ao atendimento, por meio } \\
\text { de pagamento de Taxa de matrícula, das comunidades: a) interna: } \\
\text { estudantes, professores e funcionários da UnB e, b) externa: } \\
\text { moradores do Distrito Federal. }\end{array}$ \\
\hline & $\begin{array}{l}\text { 4. implantar as atividades do Projeto, na medida do possível, nas } \\
\text { instalações do UnB Idiomas no Setor Comercial Sul - atendimento } \\
\text { à comunidade externa local, mediante o pagamento de Taxa de } \\
\text { matrícula. }\end{array}$ \\
\hline & $\begin{array}{l}\text { 5. oferecer bolsas de estudos para: a) professores e funcionários da } \\
\text { UnB e; b) estudantes dos grupos carentes } 1 \text { e } 2 \text { da UnB, na proporção } \\
\text { de } 2 \text { vagas para cada Curso/nível/turma realizada. }\end{array}$ \\
\hline & $\begin{array}{l}\text { 6. possibilitar os meios para a revisão e elaboração de material } \\
\text { didático exclusivos para os cursos. }\end{array}$ \\
\hline & $\begin{array}{l}\text { 7. gerenciar os recursos obtidos com as taxas de inscrição, } \\
\text { fornecendo as orientações financeiras das receitas/despesas do } \\
\text { projeto para a administração central da Universidade, responsável } \\
\text { pela execução dos recursos. }\end{array}$ \\
\hline & $\begin{array}{l}\text { 8. repassar o valor correspondente a } 10 \% \text { dos valores recolhidos com } \\
\text { as Taxas de matricula para o LET e de } 10 \% \text { para a Unidade } \\
\text { Central/UnB destinados aos custos indiretos realizados com o } \\
\text { Projeto. }\end{array}$ \\
\hline & 9. promover a avaliação permanente das atividades do Projeto. \\
\hline & $\begin{array}{l}\text { 5. gerenciar os recursos obtidos com as taxas de inscrição, } \\
\text { fornecendo as orientações financeiras das receitas/despesas do } \\
\text { projeto para a administração central da Universidade, responsável } \\
\text { pela execução dos recursos. }\end{array}$ \\
\hline & $\begin{array}{l}\text { Repassar o valor correspondente a } 10 \% \text { dos valores recolhidos com } \\
\text { as Taxas de inscrição para o LET e de } 10 \% \text { para a Unidade } \\
\text { Central/UnB destinados aos custos indiretos realizados com o } \\
\text { Projeto. }\end{array}$ \\
\hline & 6. promover a avaliação permanente das atividades do Projeto. \\
\hline \multirow{4}{*}{$\begin{array}{l}\text { Projeto de Cursos } \\
\text { corporativos de idiomas }\end{array}$} & $\begin{array}{l}\text { 1. possibilitar a elaboração de cursos dos idiomas como língua } \\
\text { estrangeira, a partir de métodos exclusivos desenvolvidos por } \\
\text { acadêmicos do LET, de forma a atender as demandas específicas de } \\
\text { órgãos públicos e da iniciativa privada. }\end{array}$ \\
\hline & $\begin{array}{l}\text { 2. providenciar as formalidades para a execução das atividades do } \\
\text { projeto por meio de contratos firmados com os órgãos demandantes. }\end{array}$ \\
\hline & $\begin{array}{l}\text { 3. possibilitar os meios para a revisão e elaboração de material } \\
\text { didático exclusivos para os cursos. }\end{array}$ \\
\hline & $\begin{array}{l}\text { 4. gerenciar os recursos obtidos com as taxas de matrículas, } \\
\text { fornecendo as orientações financeiras das receitas/despesas do } \\
\text { projeto para a administração central da Universidade, responsável } \\
\text { pela execução dos recursos. }\end{array}$ \\
\hline
\end{tabular}


5. repassar o valor correspondente a $10 \%$ dos valores recolhidos com as Taxas de inscrição para o LET e de $10 \%$ para a Unidade Central/UnB, destinados aos custos indiretos realizados com o Projeto.

6. promover a avaliação permanente das atividades do Projeto.

Fonte: elaboração própria a partir dos documentos do UnB Idiomas.

\subsection{Eficácias dos Projetos do UnB Idiomas: resultados e discussão}

Essa seção apresenta os dados obtidos pelo UnB Idiomas, os quais foram levantados por meio de documentos do UnB Idiomas e de informações disponíveis no Sistema de Gestão Integrada (SGI) do Programa.

O SGI é um sistema de interfaces simples que reúne e integra as informações acadêmicas, administrativas e financeiras das atividades dos Projetos. Permite funcionalidades como: a) realização de inscrições online, inclusive com a geração automática de boletos bancários para pagamentos diretamente à conta bancária conjugada com a conta única do Tesouro Nacional; b) informatização do processo de matrículas, facilitando a organização para a montagem dos cursos constantes dos Projetos; c) consolidação da receita arrecadada em tempo real; d) acesso pelos alunos a seus dados acadêmicos, feito pelo portal do aluno; e) acesso pelos professores e instrutores dos cursos para fins de lançamentos dos dados de frequência e notas dos alunos e do relatório do curso, o que é feito pelo Portal do Professor; f) banco de dados eficiente para a avaliação institucional dos cursos.

O SGI viabiliza, desde o segundo semestre do ano de 2013, avaliação dos cursos por meio eletrônico, com informações requeridas pelas normas extensionistas do Interfoco/DEX (APÊNDICE C). Desde o final do ano de 2013, a avaliação dos Indicadores de Qualidade do Programa é realizada anualmente com o objetivo de mensurar a satisfação dos alunos com relação a diversos aspectos dos cursos. Os dados são apresentados utilizando o indicador Índice de Satisfação do Aluno (ISA\%) que mensura em uma escala de $0 \%$ a $100 \%$ a satisfação do aluno com relação aos aspectos avaliados. Os resultados são apresentados utilizando a análise estatística descritiva com média, desvio padrão e índice de satisfação para cada aspecto avaliado, tais como: desempenho individual do aluno; organização administrativa e pedagógica do Programa; desempenho de professores e; satisfação geral com os cursos ofertados.

A Tabela 1 apresenta a escala de notas e seus respectivos intervalos em percentuais de satisfação. Compreende-se que o índice de satisfação geral do aluno é a melhor forma de representar a avaliação institucional global dos cursos. Esse índice é calculado a partir 
da média geral obtida, considerando a média individual de cada aspecto avaliado. $\mathrm{O}$ APÊNDICE (D) apresenta a avaliação detalhada do curso de inglês referente ao ano de 2014. Todos os cursos avaliados seguem o mesmo processo.

Tabela 1 - Descrição da escala de avaliação para o ISA.

\begin{tabular}{lcc}
\hline \multicolumn{1}{c}{ Descrição } & Índice de Satisfação do Aluno & Escala \\
\hline Discordo totalmente & $0 \%$ até $40 \%$ & 1,00 a 1,99 \\
Discordo Pouco & $41 \%$ até $60 \%$ & 2,00 a 2,99 \\
Nem discordo nem concordo & $71 \%$ até $74 \%$ & 3,00 a 3,69 \\
Concordo Pouco & $75 \%$ até $90 \%$ & 3,70 a 4,49 \\
Concordo totalmente & $91 \%$ até $100 \%$ & 4,50 a 5,00 \\
\hline
\end{tabular}

Fonte: UnB Idiomas.

De forma a orientar o processo de avaliação da eficácia do Programa, foram estabelecidas as seguintes dimensões, elaboradas a partir da leitura de documentos normativos da extensão na UnB; das orientações dispostas na Política Nacional de Extensão e; da literatura existente sobre extensão universitária, a qual tivemos acesso neste nosso estudo:

a) Dimensão da Gestão: política; infraestrutura; organização; divulgação; financiamento; resultados obtidos.

b) Dimensão Acadêmica: articulação da extensão com o ensino e pesquisa; interdisciplinaridade; interprofissionalidade; produção acadêmica; relação dialética entre teoria e prática.

c) Dimensão Discente: impacto na formação acadêmica; integralização de créditos obtidos nas ações; ampliação do universo de referência e formação cidadã.

d) Dimensão Social: interação com a sociedade; abrangência; solução de problemas; inclusão; atendimento de demandas sociais.

\subsubsection{Avaliação do Projeto de Cursos do estágio supervisionado}

Constatou-se que foram elaborados e estruturados para atendimento ao Projeto cursos dos idiomas Espanhol, Francês, Inglês e Japonês, em níveis iniciais. No caso da estrutura proposta para o curso de Inglês, foi decisão didática dos professores responsáveis pela Coordenação do curso avançar na oferta do idioma em níveis do préintermediário da língua. O Quadro 8 apresenta os elementos de organização desses cursos. 


\section{Quadro 8 - Organização dos cursos constantes do Projeto.}

\begin{tabular}{|l|l|}
\hline $\begin{array}{l}\text { Objetivo dos Cursos: prática de ensino de línguas estrangeiras, e de suas culturas, a falantes de língua } \\
\text { portuguesa, realizados para os níveis básicos dos idiomas, com enfoque comunicativo e desenvolvimento } \\
\text { das quatro habilidades linguísticas: expressão escrita e de leitura, e compreensão oral e auditiva. }\end{array}$ \\
\hline \multicolumn{1}{|c|}{ Idiomas/Cursos } & \multicolumn{1}{c|}{ Níveis/Módulos } \\
\hline PES Espanhol & Básico 1, 2 e 3 \\
\hline PESES Espanhol Infanto-Juvenil & Básico 1, 2 e 3 \\
\hline PES Francês & Básico 1, 2 e 3 \\
\hline PES Inglês & $\begin{array}{l}\text { Básico 1, 2 e 3 } \\
\text { Pré-intermediário 1, 2 e 3 }\end{array}$ \\
\hline PES Japonês & Básico 1 e 2 \\
\hline
\end{tabular}

Fonte: elaboração própria a partir de documentos do UnB Idiomas.

Todos os cursos do Projeto foram implantados no ano de 2009. No que se refere à inserção dos estudantes matriculados nas disciplinas da graduação - Estágio Supervisionado 1 e 2 - como instrutores dos cursos promovidos pelo projeto, registrou-se o atendimento de 1.014 estudantes, no período compreendido entre 2009 a 2014, conforme Tabela 2, elaborada com dados extraídos do Sistema de Graduação da UnB (SIGRA).

Tabela 2 - Estudantes matriculados em disciplinas de Estágio Supervisionado - 2009 a 2014.

\begin{tabular}{|c|c|c|c|c|c|c|c|}
\hline \multirow{2}{*}{ Curso/Nível } & \multicolumn{7}{|c|}{ Ano } \\
\hline & 2009 & 2010 & 2011 & 2012 & 2013 & 2014 & Total \\
\hline Estágio Sup. Espanhol 1 & 39 & 27 & 36 & 22 & 38 & 18 & 180 \\
\hline Estágio Sup. Espanhol 2 & 36 & 31 & 21 & 35 & 30 & 37 & 190 \\
\hline Estágio Sup. Francês 1 & 10 & 13 & 15 & 25 & 11 & 11 & 85 \\
\hline Estágio Sup. Francês 2 & 18 & 16 & 10 & 25 & 9 & 12 & 90 \\
\hline Estágio Sup. Japonês 1 & 19 & 19 & 8 & 14 & 10 & 20 & 90 \\
\hline Estágio Sup. Japonês 2 & 17 & 16 & 12 & 12 & 8 & 18 & 83 \\
\hline Estágio Sup. Inglês 1 (*) & 36 & 19 & 22 & 26 & 29 & 32 & 164 \\
\hline Estágio Sup. Inglês 2 & 24 & 24 & 20 & 20 & 17 & 27 & 132 \\
\hline Total & 199 & 165 & 144 & 179 & 152 & 175 & 1.014 \\
\hline
\end{tabular}

Fonte: elaboração própria a partir de dados extraídos do SIGRA.

Observa-se na Tabela 3 que, entre o período de 2009 a 2014, o número de alunos aprendizes matriculados nos cursos oferecidos pelo Projeto correspondeu a um total de 5.392 alunos. O atendimento para o Curso PESES Espanhol Infanto Juvenil compreendeu, no mesmo período, a um total de 3.423 alunos aprendizes da rede pública de ensino do Distrito Federal matriculados gratuitamente nos cursos. A evolução do número de inscrições/matrículas evidencia um aumento gradativo do atendimento à comunidade de alunos aprendizes. 
Tabela 3 - Número de matrículas do Projeto de estágio supervisionado - 2009 a 2014.

\begin{tabular}{lcccccccc}
\hline \multirow{2}{*}{ Curso } & \multicolumn{7}{c}{ Ano } & \multirow{2}{*}{ Total } \\
\cline { 2 - 7 } & $\mathbf{2 0 0 9}$ & $\mathbf{2 0 1 0}$ & $\mathbf{2 0 1 1}$ & $\mathbf{2 0 1 2}$ & $\mathbf{2 0 1 3}$ & $\mathbf{2 0 1 4}$ & \\
\cline { 2 - 7 } PES Espanhol & 47 & 72 & 94 & 89 & 84 & 92 & 478 \\
PESES Espanhol Infanto Juvenil & 201 & 597 & 726 & 554 & 617 & 728 & 3.423 \\
PES Francês & 48 & 36 & 47 & 62 & 219 & 189 & 601 \\
PES Inglês & 72 & 88 & 83 & 56 & 152 & 159 & 610 \\
PES Japonês & 12 & 21 & 13 & 83 & 49 & 102 & 280 \\
\hline \multicolumn{1}{c}{ Total } & $\mathbf{3 8 0}$ & $\mathbf{8 1 4}$ & $\mathbf{9 6 3}$ & $\mathbf{8 4 4}$ & $\mathbf{1 1 2 1}$ & $\mathbf{1 2 7 0}$ & $\mathbf{5 . 3 9 2}$ \\
\hline
\end{tabular}

Fonte: elaboração própria a partir de dados extraídos do SGI.

A avaliação geral dos cursos do Projeto, feita pelos alunos aprendizes, apresenta um índice de qualidade em torno de 70\%, conforme Gráfico 1. Observa-se, no mesmo Quadro, que a avaliação de qualidade realizada para o desempenho dos instrutores foi de $75,5 \%$, o que demonstra que os estudantes da disciplina de Estágio Supervisionado 1 e 2 que atuam como instrutores dos cursos têm recebido uma avaliação satisfatória pelos alunos aprendizes.

\section{Gráfico 1 - Indicadores de qualidade de avaliação geral dos Cursos - 2014 ${ }^{(2)}$}

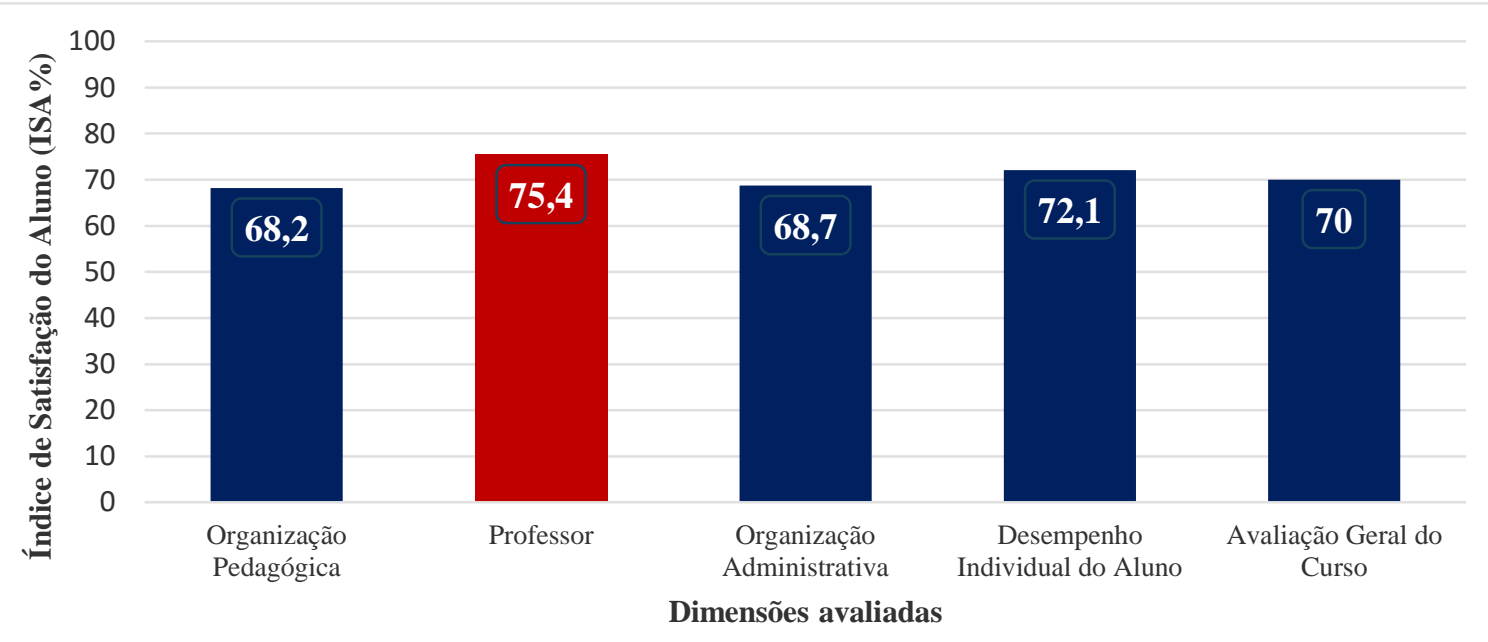

Fonte: elaboração própria a partir de dados extraídos do SGI. ${ }^{2}$

\footnotetext{
${ }^{2}$ A avaliação refere-se a análise de todas as dimensões, que engloba todos os idiomas ofertados pelo Projeto.
} 
No Gráfico 2 são apresentados os índices de avaliação geral dos cursos por idioma, sendo que os cursos do idioma Japonês apresentaram a melhor avaliação entre os cursos oferecidos pelo Projeto, com índice de qualidade geral de aproximadamente $85 \%{ }^{3}$.

\section{Gráfico 2 - Indicadores de qualidade dos cursos por idioma - 2014}

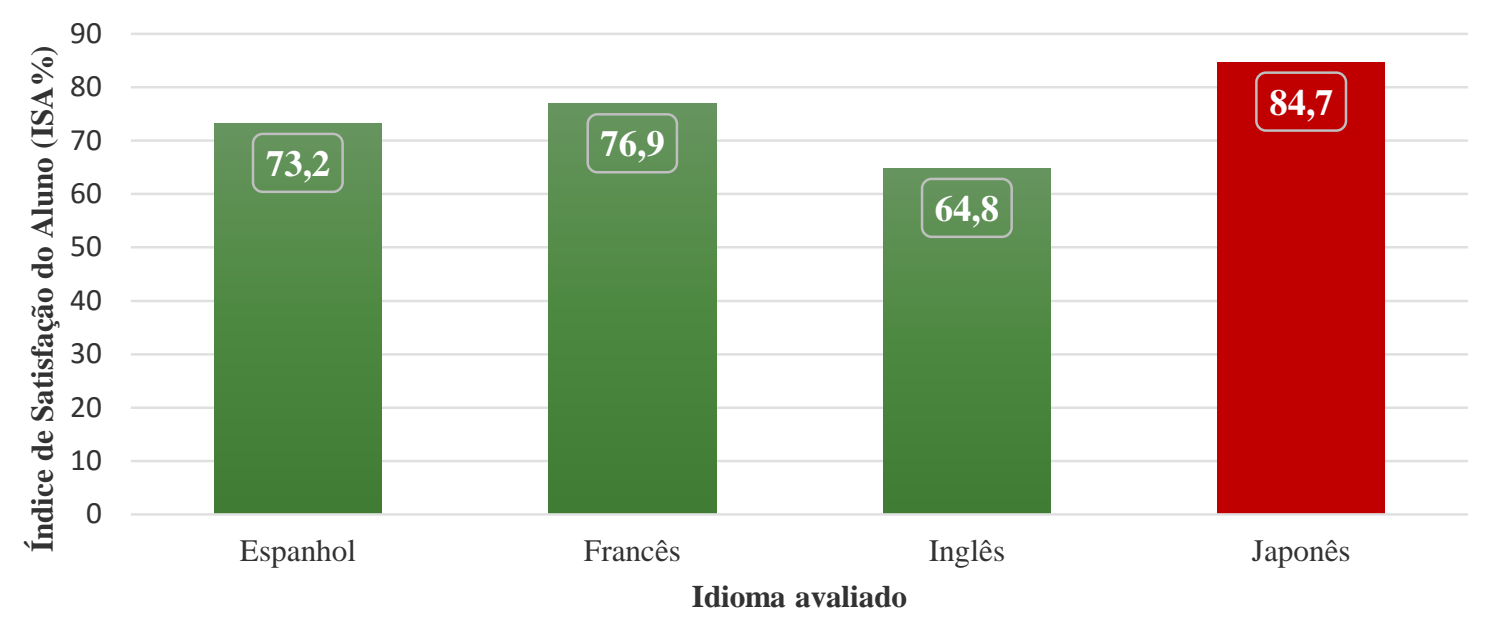

Fonte: elaboração própria a partir de dados extraídos do SGI.

Os materiais didáticos adotados para os Cursos de Espanhol, Francês e Inglês são definidos pelos professores do LET e avaliados permanentemente por eles e pelos estudantes/instrutores, como práxis didáticas da disciplina de Estágio Supervisionado. No caso particular dos cursos do idioma Japonês o material didático aplicado em sala de aulas é elaborado pelos próprios professores do LET, e disponibilizados para os alunos aprendizes na forma de apostilas. Esse material sofre adaptações e inclusões sempre que uma nova estratégia didática para o ensino do idioma é alterada ou incluída.

As aulas acontecem em salas de aulas do campus universitário Darcy Ribeiro, exclusivamente, em dias e horários da semana definidos pelos Coordenadores. Os Cursos/turmas do PESES Espanhol Infanto Juvenil acontecem aos sábados, das 8h às 12h, de forma a facilitar a participação dos alunos da rede de ensino do DF.

Avaliação da eficácia: impacto na formação dos estudantes; enriquecimento da experiência em termos teóricos e metodológicos; aproximação da universidade com a sociedade; relação da extensão com a graduação; produção acadêmica; cumprimento dos

\footnotetext{
${ }^{3}$ Média geral da avaliação das dimensões considerando cada idioma.
} 
objetivos do Programa; atendimento a segmento específico da sociedade; abrangência das ações.

\subsubsection{Avaliação do Projeto de Cursos abertos sequenciais de idiomas}

Para a implantação do Projeto no início do ano de 2009, foram elaborados e implantados, prioritariamente, os cursos sequenciais dos idiomas Espanhol, Francês e Inglês. Já no segundo semestre daquele mesmo ano, foram elaborados e implementados os Cursos sequenciais dos idiomas Alemão, Árabe, Hebraico, Japonês, Mandarim e Russo. O Curso de Grego moderno foi elaborado e implementado no ano de 2010, os dos idiomas Coreano e Esperanto no ano de 2012 e, no ano de 2013 foi elaborado e implantado o Curso do idioma Turco.

Os Cursos de idiomas menos convencionais, a exemplo dos idiomas Árabe e Mandarim, contaram para a sua elaboração com as recomendações acadêmicas de professores leitores estrangeiros, os quais atuam na universidade por meio de Acordos de cooperação estabelecidos com aqueles países. Outra participação vem das Embaixadas sediadas em Brasília, que têm apoiado as iniciativas do Projeto, em especial no apoio aos eventos destinados à promoção cultural dos países, aspecto fundamental para o processo de ensino/aprendizagem de idiomas.

As atividades promovidas pelo Instituto Confúcio da UnB, cuja gestão é realizada pelo Programa, desde o ano de 2009, por meio do Acordo de cooperação com o Governo da República Popular da China, tem possibilitado a participação de acadêmicos e estudantes de diversas unidades acadêmicas da UnB em palestras, cursos, conferências, eventos culturais e intercâmbio desses com outras universidades chinesas. O Quadro 9 apresenta as informações relativas à organização dos Cursos constantes desse Projeto:

\section{Quadro 9 - Organização dos Cursos sequenciais de idiomas do Projeto.}

Objetivo dos Cursos: ensino de línguas estrangeiras, e de suas culturas, a falantes de língua portuguesa, com estrutura modular sequencial, enfoque comunicativo e desenvolvimento das quatro habilidades linguísticas: expressão escrita e de leitura, e compreensão oral e auditiva.

\begin{tabular}{|l|l|}
\hline \multicolumn{1}{|c|}{ Cursos } & \multicolumn{1}{c|}{ Estrutura/Módulos } \\
\hline \multirow{2}{*}{$\begin{array}{l}\text { Alemão; Árabe; Coreano; Espanhol; Esperanto; Francês, Grego } \\
\text { (moderno); Hebraico; Mandarim; Russo; Turco. }\end{array}$} & Básico 1, 2 e 3 \\
\cline { 2 - 2 } & Intermediário 1, 2 e 3 \\
\cline { 2 - 2 } & Avançado 1, 2 e 3 \\
\hline \multirow{2}{*}{ Inglês } & Básico 1, 2 e 3 \\
\cline { 2 - 2 } & Pré-Intermediário 1, 2 e 3 \\
\cline { 2 - 2 } & Intermediário 1, 2 e 3 \\
\cline { 2 - 2 } & Avançado 1, 2 e 3 \\
\hline \multirow{2}{*}{ Japonês } & Básico 1, 2, 3, 4 e 5 \\
\cline { 2 - 2 } & Intermediário 1, 2, 3, 4 e 5 \\
\cline { 2 - 2 } & Avançado 1, 2 e 3 \\
\hline \hline
\end{tabular}

Fonte: elaboração própria a partir de documentos do UnB Idiomas. 


\subsubsection{O projeto em números}

No período de 2009 a 2014, o Projeto atendeu a 68.942 mil matrículas realizadas em todos os campi e todos os cursos de idiomas realizados no período de 2009 a 2014. A Tabela 4 detalha a distribuição do número total dessas matrículas por idioma.

No ano de 2009 a demanda por cursos apresentou um total de 3.187 mil alunos matriculados em 10 idiomas. A partir de 2010, com a oferta de cursos nos períodos de inverno (julho) e verão (janeiro e fevereiro), o número de matrículas atingiu o número de 7.950 mil matrículas efetivadas, cerca de $250 \%$ acima do número de matrículas realizadas no ano de 2009. Em 2014, o número de matrículas em ofertas dos Cursos do Projeto atingiu o número de 16.754 mil alunos matriculados. O Gráfico 3 mostra a evolução do número de alunos matriculados no período de 2009 a 2014.

O idioma Alemão foi o que apresentou maior crescimento de matrículas no período entre 2009 a 2014. Em 2014 os cursos de Alemão somaram a 1.112 alunos matriculados, $585,2 \%$ de crescimento se comparado ao ano de 2009 . A ocupação do Curso de Alemão tem sido na proporção de $70 \%$ para a comunidade interna e $30 \%$ para a comunidade externa.

Tabela 4 - Evolução do número de alunos matriculados por idioma nos Cursos abertos 2009 a 2014

\begin{tabular}{rcccccccc}
\hline Idioma & $\mathbf{2 0 0 9}$ & $\mathbf{2 0 1 0}$ & $\mathbf{2 0 1 1}$ & $\mathbf{2 0 1 2}$ & $\mathbf{2 0 1 3}$ & $\mathbf{2 0 1 4}$ & Total & Matrículas \% \\
\hline Alemão & 19 & 134 & 350 & 729 & 969 & 1.112 & $\mathbf{3 . 3 1 3}$ & 4,8 \\
Árabe & 16 & 25 & 20 & 19 & 12 & - & $\mathbf{9 2}$ & 0,1 \\
Coreano & - & - & - & 23 & 62 & 38 & $\mathbf{1 2 3}$ & 0,2 \\
Espanhol & 694 & 1.206 & 1.464 & 1.857 & 1.844 & 1.395 & $\mathbf{8 . 4 6 0}$ & 12,3 \\
Esperanto & - & - & - & 14 & 50 & 20 & $\mathbf{8 4}$ & 0,1 \\
Francês & 747 & 1.931 & 2.622 & 3.132 & 3.097 & 3.059 & $\mathbf{1 4 . 5 8 8}$ & 21,2 \\
Grego Moderno & - & 17 & 6 & 14 & 4 & 14 & $\mathbf{5 5}$ & 0,1 \\
Hebraico & 14 & 22 & 24 & 24 & 33 & 37 & $\mathbf{1 5 4}$ & 0,2 \\
Inglês & 1.473 & 3.991 & 5.150 & 7.493 & 9.072 & 9.952 & $\mathbf{3 7 . 1 3 1}$ & 53,9 \\
Italiano & 101 & 234 & 315 & 387 & 456 & 464 & $\mathbf{1 . 9 5 7}$ & 2,8 \\
Japonês & 77 & 210 & 222 & 348 & 250 & 300 & $\mathbf{1 . 4 0 7}$ & 2,0 \\
Mandarim & 31 & 140 & 219 & 213 & 339 & 254 & $\mathbf{1 . 1 9 6}$ & 1,7 \\
Russo & 15 & 40 & 64 & 58 & 85 & 101 & $\mathbf{3 6 3}$ & 0,5 \\
Turco & - & - & - & - & 11 & 8 & $\mathbf{1 9}$ & 0,0 \\
\hline Total & $\mathbf{3 . 1 8 7}$ & $\mathbf{7 . 9 5 0}$ & $\mathbf{1 0 . 4 5 6}$ & $\mathbf{1 4 . 3 1 1}$ & $\mathbf{1 6 . 2 8 4}$ & $\mathbf{1 6 . 7 5 4}$ & $\mathbf{6 8 . 9 4 2}$ & $\mathbf{1 0 0 , 0}$ \\
\hline
\end{tabular}

Fonte: elaboração própria a partir de dados extraídos do SGI. 
Gráfico 3 - Evolução do número de matrículas em Cursos abertos sequenciais 2009 a 2014.

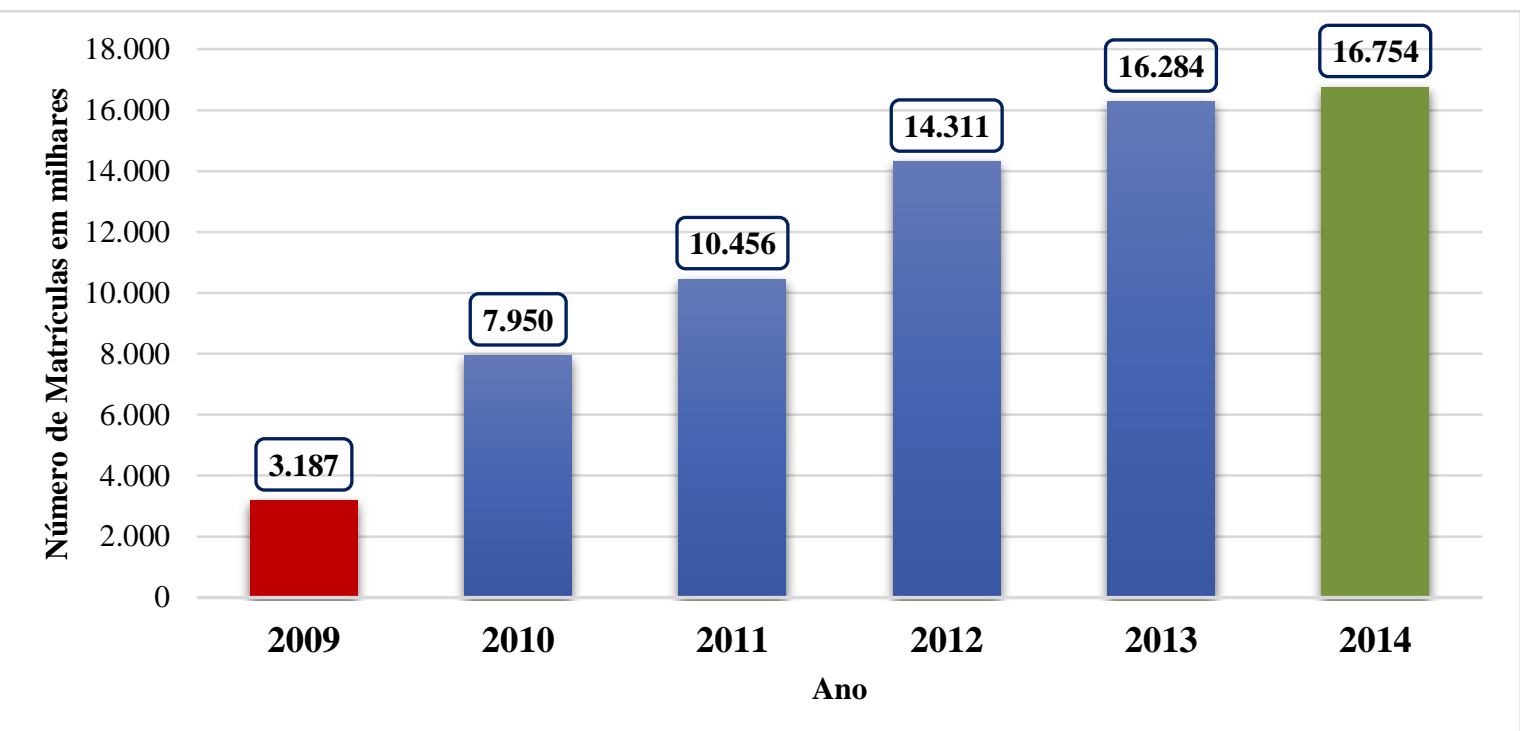

Fonte: elaboração própria a partir de dados extraídos do SGI.

A demanda dos Cursos abertos sequenciais é distribuída proporcionalmente em alunos aprendizes da comunidade interna e comunidade externa. No período de 2009 a 2014, a demanda de matrículas nesses dois segmentos foi proporcionalmente equilibrada, como demonstra a Tabela 5. Em dados analisados até 2014, foram atendidos 34.729 alunos da comunidade interna ou 50,4 \% das matrículas realizadas no Projeto (Gráfico 4).

Tabela 5 - Distribuição do número de matrículas por público participante.

\begin{tabular}{cccccc}
\hline Período & Público Externo & Público Externo \% & Público Interno & Público Interno \% & Total \\
\hline 2009 & 1.581 & 49,6 & 1.606 & 50,4 & $\mathbf{3 . 1 8 7}$ \\
2010 & 4.062 & 51,1 & 3.888 & 48,9 & $\mathbf{7 . 9 5 0}$ \\
2011 & 5.071 & 48,5 & 5.385 & 51,5 & $\mathbf{1 0 . 4 5 6}$ \\
2012 & 7.413 & 51,8 & 6.898 & 48,2 & $\mathbf{1 4 . 3 1 1}$ \\
2013 & 8.191 & 50,3 & 8.093 & 49,7 & $\mathbf{1 6 . 2 8 4}$ \\
2014 & 8.411 & 50,2 & 8.343 & 49,8 & $\mathbf{1 6 . 7 5 4}$ \\
\hline Total & $\mathbf{3 4 . 7 2 9}$ & $\mathbf{5 0 , 4}$ & $\mathbf{3 4 . 2 1 3}$ & 49,6 & $\mathbf{6 8 . 9 4 2}$ \\
\hline
\end{tabular}

Fonte: elaboração própria a partir de dados extraídos do SGI. 


\section{Gráfico 4 - Distribuição da demanda para o público externo e interno matriculados em Cursos Abertos.}

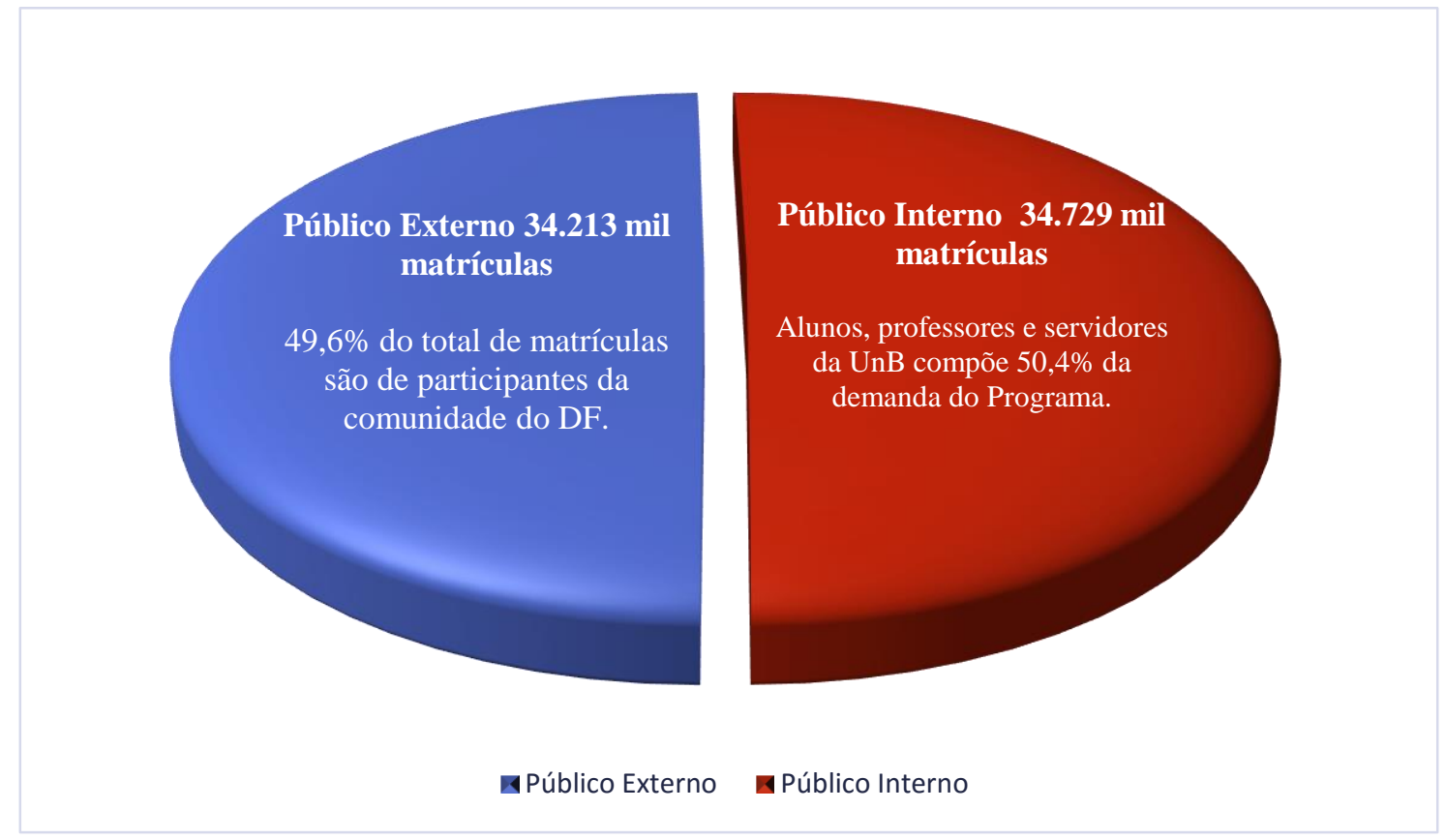

Fonte: elaboração própria a partir de dados extraídos do SGI.

A avaliação geral dos cursos do Projeto de cursos abertos sequenciais realizada no ano de 2014, apresenta índices de satisfação na faixa de $70 \%$ para as dimensões avaliadas. No Gráfico 5 consta as avaliações de cada dimensão, sendo que o desempenho dos professores recebeu o maior índice de satisfação, 79,6\%, seguida do desempenho individual do aluno no decorrer do curso, com $77 \%$.

\section{Gráfico 5 - Indicadores de qualidade de avaliação geral dos cursos - 2014.}

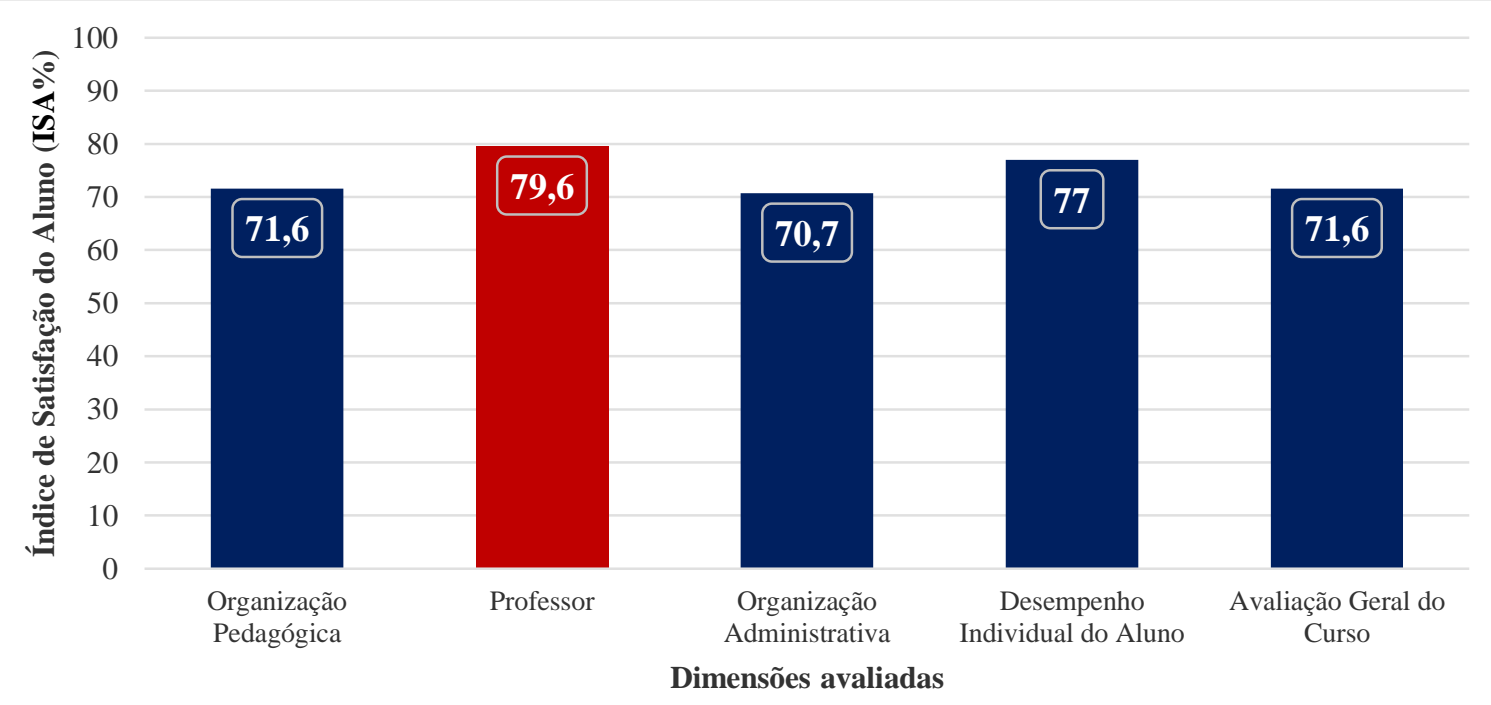

Fonte: elaboração própria a partir de dados extraídos do SGI. 
No Gráfico 6 são apresentados os índices da avaliação geral dos cursos por idioma, sem distinção de nível ou dimensão avaliada. Cursos como Hebraico e Coreano se destacaram no período de 2014, com índice de satisfação geral de 94,1\% e 91,2\%, respectivamente.

Gráfico 6 - Indicadores de qualidade dos cursos por idioma - 2014.

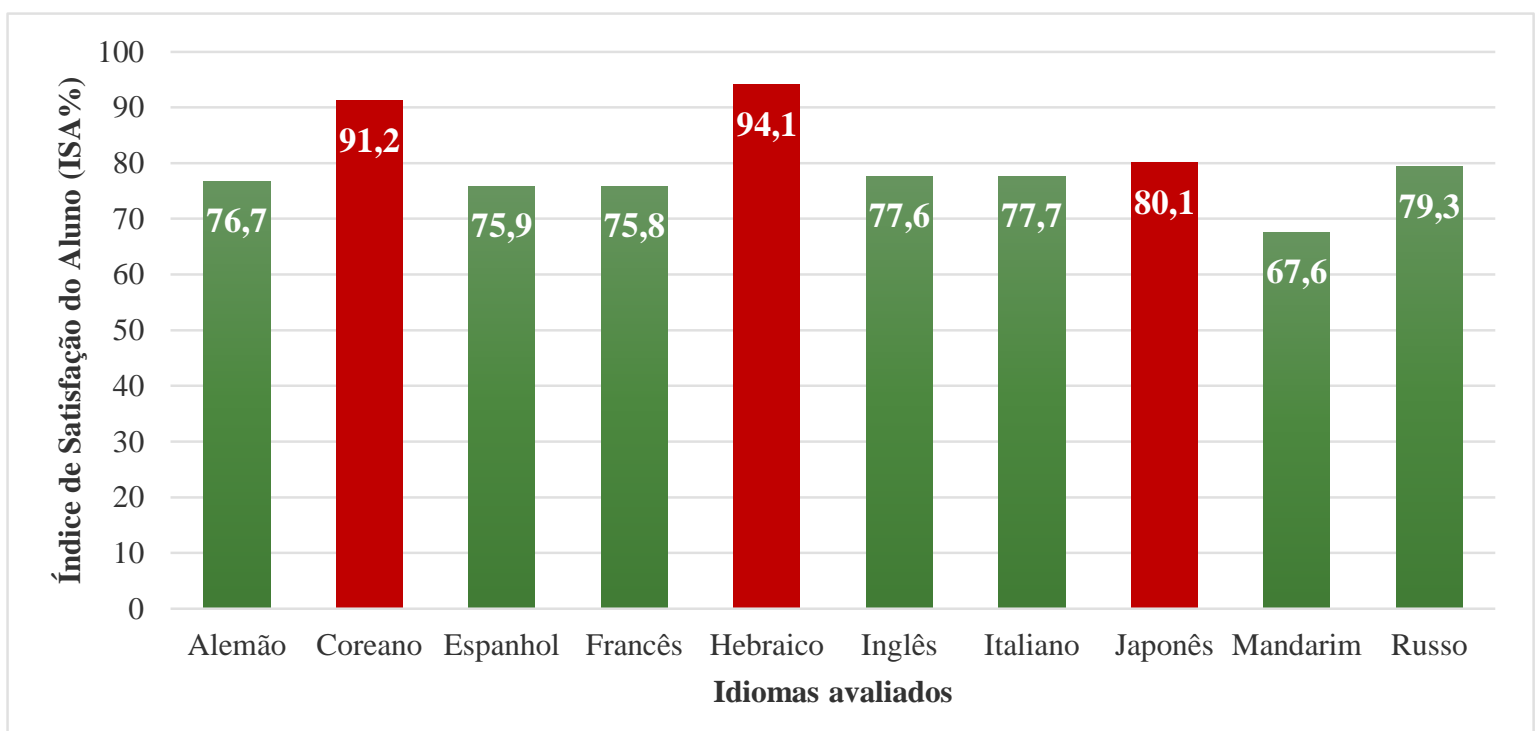

Fonte: elaboração própria a partir de dados extraídos do SGI.

\subsubsection{Cursos de Idiomas para a $3^{\text {a }}$. Idade}

Os cursos para a $3^{\text {a }}$. Idade foram elaborados e implementados no ano de 2010, o objetivo e estruturas dos cursos encontram-se demonstradas no Quadro 10.

\section{Quadro 10 - Organização dos cursos de idiomas para a $3^{\text {a }}$. Idade.}

\begin{tabular}{|c|c|}
\hline \multicolumn{2}{|c|}{$\begin{array}{l}\text { Objetivo dos Cursos: ensino de línguas estrangeiras, e de suas culturas, a falantes de língua portuguesa, } \\
\text { com estrutura modular sequencial, enfoque comunicativo e desenvolvimento das quatro habilidades } \\
\text { linguísticas: expressão escrita e de leitura, e compreensão oral e auditiva. }\end{array}$} \\
\hline Cursos & Estrutura/Módulos \\
\hline \multirow{5}{*}{ Inglês } & Iniciante 1,2 e 3 \\
\hline & Básico 1,2 e 3 \\
\hline & Pré-intermediário 1,2 e 3 \\
\hline & Intermediário 1,2 e 3 \\
\hline & Avançado 1,2 e 3 \\
\hline \multirow{3}{*}{ Espanhol; Francês } & Básico 1,2 e 3 \\
\hline & Intermediário 1,2 e 3 \\
\hline & Avançado 1,2 e 3 \\
\hline
\end{tabular}

Fonte: elaboração própria a partir de documentos do UnB Idiomas. 
Conforme demonstra a Tabela 6, no período de 2010 a 2014 ocorreram um total de 2.471 matrículas, distribuídas entre os idiomas Espanhol, Francês e Inglês. O Curso do Idioma Inglês é o que responde pelo maior número de matrículas, na ordem de 1.607 matrículas realizadas no período. A demanda por esse tipo de curso cresceu $435 \%$ entre os anos de 2010 e 2014. Alunos da comunidade externa respondem atualmente por $97 \%$ da ocupação das vagas. O Gráfico 7 mostra a evolução do número de matrículas nesse tipo de curso no período de 2010 a 2014. Esses cursos acontecem no campus Asa Norte e instalações do UnB Idiomas no Setor Comercial Sul.

Tabela 6 - Evolução do número de matrículas dos cursos para a $3^{\circ}$ Idade - 2010 a 2014

\begin{tabular}{ccccccc}
\hline Idioma & $\mathbf{2 0 1 0}$ & $\mathbf{2 0 1 1}$ & $\mathbf{2 0 1 2}$ & $\mathbf{2 0 1 3}$ & $\mathbf{2 0 1 4}$ & Total \\
\hline Espanhol & 43 & 87 & 106 & 78 & 80 & 394 \\
Francês & 33 & 68 & 98 & 129 & 142 & 470 \\
Inglês & 94 & 221 & 358 & 417 & 517 & 1.607 \\
\hline Total & $\mathbf{1 7 0}$ & $\mathbf{3 7 6}$ & $\mathbf{5 6 2}$ & $\mathbf{6 2 4}$ & $\mathbf{7 3 9}$ & $\mathbf{2 . 4 7 1}$ \\
\hline
\end{tabular}

Fonte: elaboração própria a partir de dados extraídos do SGI.

Gráfico 7 - Evolução do número de matrículas em cursos para a $3^{\text {a }}$ Idade -2010 a 2014.

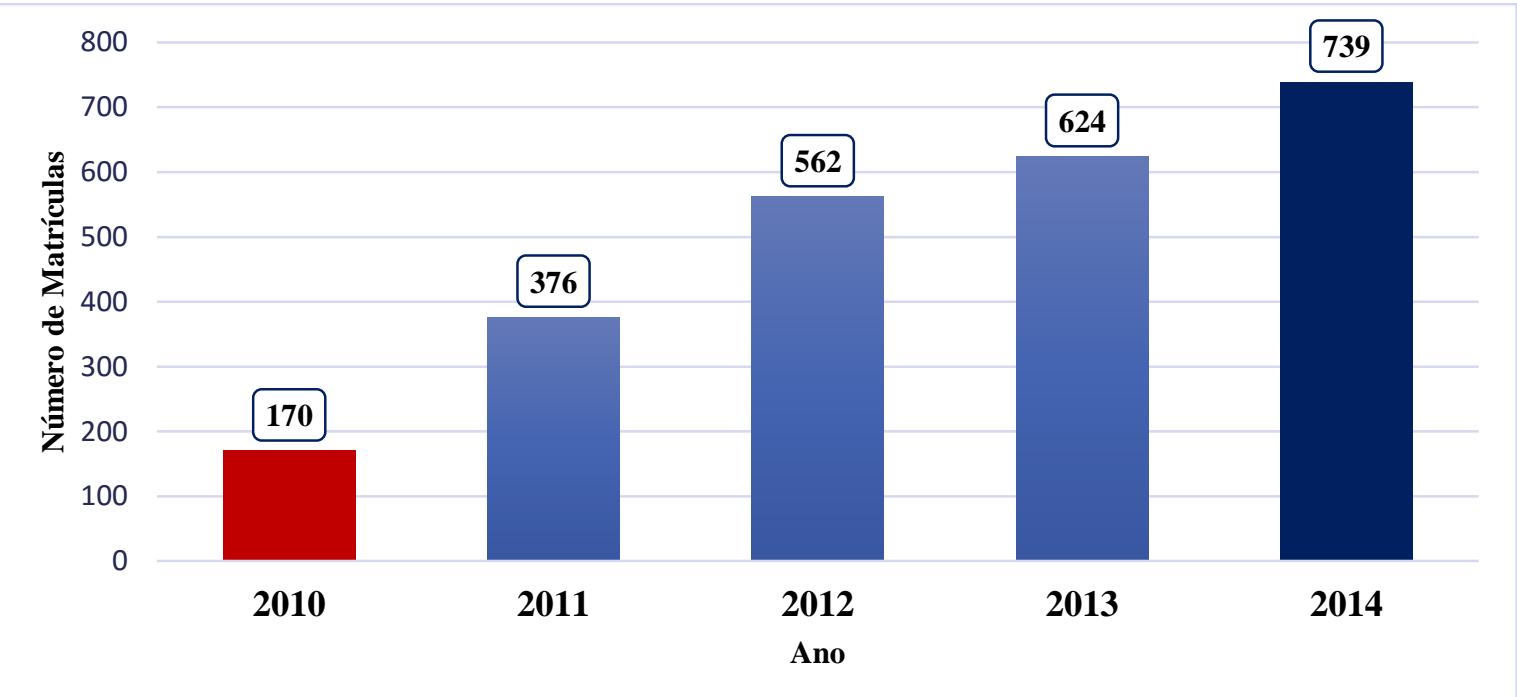

Fonte: elaboração própria a partir de dados extraídos do SGI.

Os cursos da $3^{\circ}$ idade passam também pelo processo de avaliação institucional do UnB Idiomas. O Gráfico 8 apresenta a avaliação institucional dos Indicadores de Qualidade por dimensão avaliada, o que engloba todos os idiomas sem diferenciá-los, realizando, portanto, uma avaliação geral dos cursos. Avaliação geral dos cursos obteve 
um índice de satisfação em torno de $80 \%$, destacando-se a dimensão que mensura o desempenho individual do aluno, como $85 \%$ de satisfação geral. Outro destaque é a dimensão que avalia o desempenho dos professores ao longo dos cursos, com $82 \%$ de satisfação geral.

\section{Gráfico 8 - Indicadores de qualidade de avaliação geral dos cursos - 2014.}

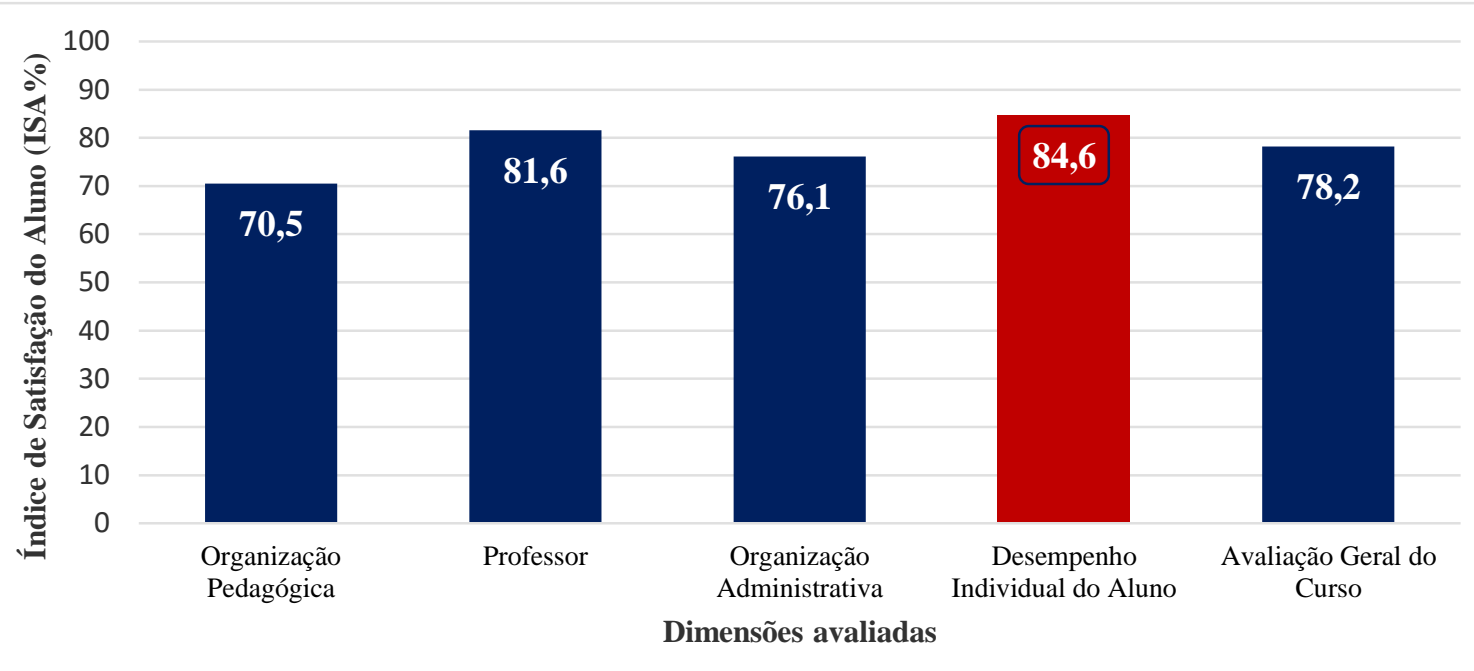

Fonte: elaboração própria a partir de dados extraídos do SGI.

O Gráfico 9 mensura o desempenho dos indicadores de qualidade geral de cada idioma. Os três idiomas que compõe os cursos para a $3^{\mathrm{a}}$ idade são avaliados com índices de satisfação superior a $80 \%$.

Gráfico 9 - Indicadores de qualidade dos cursos por idioma - 2014.

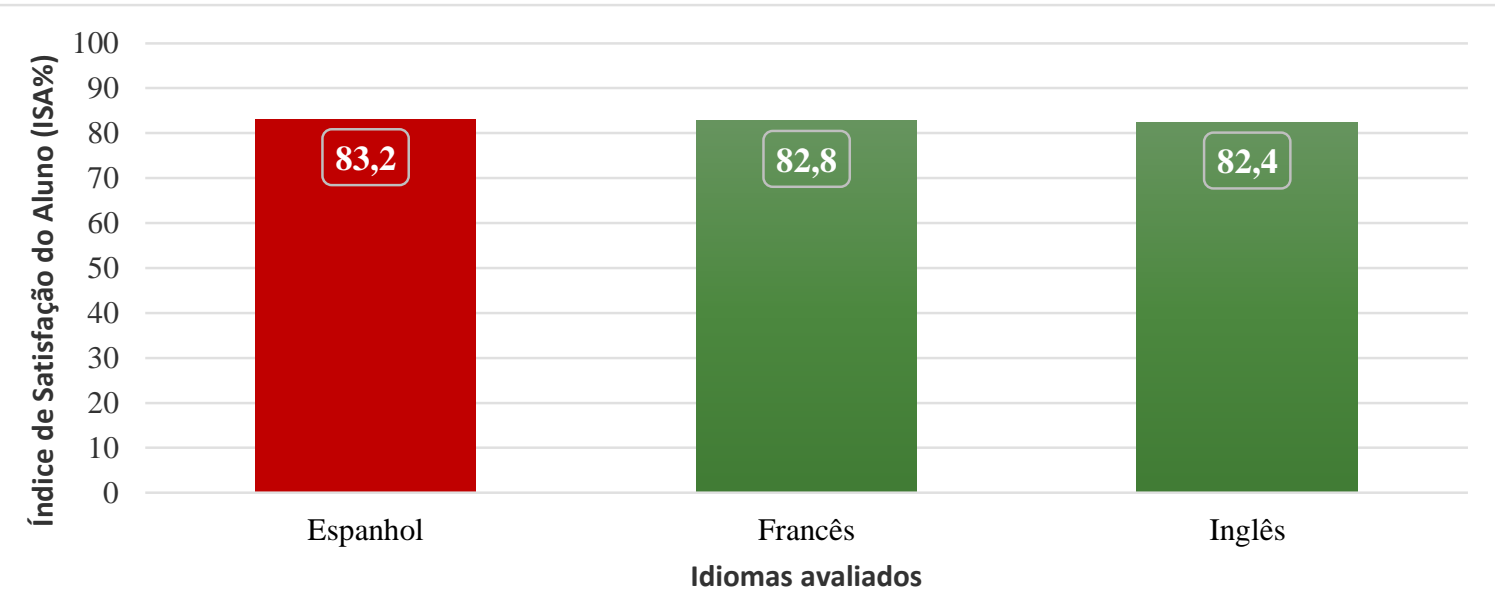

Fonte: elaboração própria a partir de dados extraídos do SGI. 


\subsubsection{Cursos de idiomas com finalidades específicas}

O Quadro 11 apresenta os Cursos com finalidades especificas atualmente realizados pelo Projeto. O Curso de Inglês Advanced e os Curso de Inglês Instrumental foram elaborados e implantados ainda no ano de 2009. O Inglês Instrumental 1 e 2 foram elaborados para atendimento aos alunos da pós-graduação da universidade. Os cursos são ofertados somente no campus da Asa Norte.

\section{Quadro 11 - Organização dos cursos com finalidade específica.}

\begin{tabular}{|c|c|}
\hline \multicolumn{2}{|c|}{$\begin{array}{l}\text { Cursos de Conversação: tem como objetivo fornecer instrumentos necessários para aperfeiçoar as } \\
\text { habilidades linguísticas de produção e compreensão oral da língua estrangeira estudada. }\end{array}$} \\
\hline $\begin{array}{ll} & \text { Cursos } \\
\end{array}$ & Estrutura/Módulos \\
\hline Inglês & Advanced 1,2 e 3 \\
\hline Francês & Conversação \\
\hline \multicolumn{2}{|c|}{$\begin{array}{l}\text { Cursos Instrumentais: tem como objetivo capacitar os aprendizes para ler, compreender e traduzir } \\
\text { textos escritos em outros idiomas }\end{array}$} \\
\hline Francês & Instrumental \\
\hline \multirow{2}{*}{ Inglês } & Instrumental 1 e 2 \\
\hline & Instrumental para concursos \\
\hline
\end{tabular}

Fonte: elaboração própria a partir de documentos do UnB Idiomas.

\subsubsection{Cursos de idiomas preparatórios para Exames de Proficiência}

Os Cursos de idiomas preparatórios para Exames de Proficiência foram elaborados no ano de 2012, a pedido da Assessoria de Assuntos Internacionais da UnB, na intenção de apoiar os alunos da Universidade para a participação no Programa Ciência sem Fronteiras. Foi disponibilizado pela administração crédito financeiro na ordem de R\$ 11.000,00 para a elaboração e implementação de uma turma do Curso Preparatório para Prova de Proficiência de Inglês - TOELF e uma turma do Curso Preparatório para a prova de Proficiência de Francês - DELF, com atendimento gratuito para alunos selecionados a partir de provas de nivelamento realizadas também pelo UnB Idiomas.

Estes Cursos foram posteriormente inseridos no catálogo de cursos do Projeto de Cursos abertos sequenciais de idiomas, sendo oferecidos a comunidade interna e externa à UnB, mediante o pagamento de taxas de matrículas. O Curso Preparatório para Exame de Proficiência do idioma Espanhol - DELE foi elaborado no ano de 2014, não tendo sido implantadas turmas até aquele ano. Os cursos também ocorrem somente no campus da UnB na Asa Norte. O Quadro 12 apresenta a organização desses cursos. 
Quadro 12 - Organização dos Cursos preparatórios para Exames de Proficiência.

\begin{tabular}{|l|l|}
\hline \hline \multicolumn{2}{|l|}{ Objetivo: tem como objetivo a revisão linguística, prática de resolução de exercícios similares } \\
ao exame de proficiência e aplicação de testes simulados. \\
\hline Cursos & Estrutura/Módulos \\
\hline Inglês & Preparatório TOEFL \\
\hline Francês & Preparatório DELF B2 \\
\hline Espanhol & Preparatório DELE \\
\hline \hline
\end{tabular}

Fonte: elaboração própria a partir de documentos do UnB Idiomas.

\subsubsection{Cursos temáticos de idiomas}

Os Cursos temáticos de idiomas, produzidos por estudantes e professores da pósgraduação do LET e oferecidos conforme as orientações estabelecidas por estes, tem sido oferecido, mediante pagamento de taxa de matrícula, desde o ano de 2010. Os cursos são realizados exclusivamente no campus Darcy Ribeiro e atendem, principalmente, à comunidade universitária do campus da Asa Norte. O Quadro 13 apresenta os cursos realizados no período de 2010 a 2014.

Considerando que estes cursos não apresentam regularidade na sua realização, não foram considerados os dados relativos a eles para a pesquisa.

\section{Quadro 13 - Organização dos cursos temáticos.}

\begin{tabular}{|c|c|c|}
\hline Idioma & Curso & Objetivo \\
\hline \multirow{3}{*}{ Francês } & $\mathrm{Na}$ Classe em Cena & Não localizado \\
\hline & Cinema Belga Francófono & $\begin{array}{l}\text { Abordagem da cultura artística francófona, através } \\
\text { da prática do francês com um material } \\
\text { diferenciado e interativo. Através do suporte } \\
\text { audiovisual, os participantes vão se confrontar } \\
\text { também à cultura belga quotidiana por meio das } \\
\text { representações do modo de vida e culturas Belgas. }\end{array}$ \\
\hline & $\begin{array}{l}\text { O fantástico em Guy de } \\
\text { Maupassant }\end{array}$ & $\begin{array}{l}\text { Abordagens do texto literário, no caso específico, } \\
\text { os contos de Guy de Maupassant, estimular nos } \\
\text { alunos o prazer da aprendizagem da língua } \\
\text { francesa através da literatura. }\end{array}$ \\
\hline \multirow{5}{*}{ Inglês } & Academic Writing 1, 2 e 3 & $\begin{array}{l}\text { familiarização com as normas gerais de publicação } \\
\text { científica, bem como a produção de artigos } \\
\text { científicos em inglês }\end{array}$ \\
\hline & Book Club English & $\begin{array}{l}\text { praticar a leitura de livros das literaturas norte- } \\
\text { americana, irlandesa e inglesa }\end{array}$ \\
\hline & Bussiness Communication & $\begin{array}{l}\text { Aborda as habilidades comunicativas } \\
\text { compreensão, fala e escrita - para capacitar o aluno } \\
\text { a tratar sobre os diversos temas de negócios } \\
\text { (Gestão, Marketing, Finanças, etc.). }\end{array}$ \\
\hline & Business \& Leadership & $\begin{array}{l}\text { negócios nas suas várias vertentes (marketing, } \\
\text { gerenciamento, consultoria, finanças, etc.). }\end{array}$ \\
\hline & Cinema & $\begin{array}{l}\text { tem como foco o cinema e sua história, gêneros, } \\
\text { diretores e trilhas sonoras }\end{array}$ \\
\hline
\end{tabular}




\begin{tabular}{|c|c|c|}
\hline & $\begin{array}{l}\text { English Phonetics and } \\
\text { Phonology for ESL Teachers }\end{array}$ & $\begin{array}{l}\text { fomentar uma auto avaliação e análise fonética } \\
\text { mais aprofundada. Este ponto será alcançado por } \\
\text { meio da habilitação da consciência vocal e } \\
\text { utilização de variados exercícios de identificação e } \\
\text { transcrição fonétic }\end{array}$ \\
\hline & $\begin{array}{l}\text { English Phonetics and } \\
\text { Pronunciation }\end{array}$ & $\begin{array}{l}\text { tem como enfoque a fonética e a fonologia da } \\
\text { língua inglesa. Visa o aperfeiçoamento da } \\
\text { pronúncia por meio da aprendizagem dos sons } \\
\text { vocálicos e consonantais do inglês, suas } \\
\text { articulações, acentuação, ritmo e entonação }\end{array}$ \\
\hline & Let's Talk! & $\begin{array}{l}\text { voltado para alunos iniciantes que querem } \\
\text { destravar a língua, melhorar sua pronúncia, } \\
\text { melhorar o listening, revisar e adquirir vocabulário } \\
\text { e estruturas essenciais da língua que edificam uma } \\
\text { melhor comunicação, consertar vícios de } \\
\text { linguagem. }\end{array}$ \\
\hline & Tolkien \& Fantasy Literature & $\begin{array}{l}\text { analisar trechos das obras do escritor J. R. R. } \\
\text { Tolkien e a influência que suas obras tiveram no } \\
\text { cinema e RPG (Role-playing game)/Cards Games. }\end{array}$ \\
\hline Italiano & Filmes Italianos & $\begin{array}{l}\text { Revisão de estruturas da língua, vocabulário, } \\
\text { expressões idiomáticas, gírias, registro informal, } \\
\text { pronuncia por meio de filmes italianos. }\end{array}$ \\
\hline Japonês & Oralização do Conto Narrativo & Não localizado \\
\hline Mandarim & $\begin{array}{l}\text { Introdução ao Pensamento } \\
\text { Chinês }\end{array}$ & $\begin{array}{l}\text { Tem como foco a prática da oralidade a partir da } \\
\text { compreensão da cultura e hábitos da China }\end{array}$ \\
\hline
\end{tabular}

Fonte: elaboração própria a partir de documentos do UnB Idiomas.

\subsubsection{Demanda de matrículas dos Cursos abertos sequenciais por campi}

Os Cursos abertos sequenciais de idiomas foram implementados inicialmente no campus da UnB na Asa Norte e posteriormente as atividades foram expandidas para os campi da UnB no Gama e em Planaltina no ano de 2012 e, campus da UnB na Ceilândia em 2013.

As Tabelas 7, 8 e 9 representam a evolução do número de matrículas no campus da UnB na Asa Norte, campi da UnB no Gama, Planaltina e Ceilândia e Setor Comercial Sul, respectivamente. A oferta de cursos se concentra no campus da UnB na Asa Norte, que responde por cerca de $89 \%$ ou 61.770 mil matrículas, enquanto os campi da UnB Gama, Planaltina e Ceilândia e o Setor Comercial Sul somaram cerca de 11\%, ou 7.172 mil matrículas no período de 2012 a 2014. 
Tabela 7 - Evolução de matrículas campus Asa Norte - 2009 a 2014

\begin{tabular}{lccccccc}
\hline \multicolumn{1}{c}{ Idioma } & $\mathbf{2 0 0 9}$ & $\mathbf{2 0 1 0}$ & $\mathbf{2 0 1 1}$ & $\mathbf{2 0 1 2}$ & $\mathbf{2 0 1 3}$ & $\mathbf{2 0 1 4}$ & Total \\
\hline Alemão & 19 & 134 & 350 & 692 & 871 & 1.030 & 3.096 \\
Árabe & 16 & 25 & 20 & 19 & 12 & - & 92 \\
Coreano & - & - & - & 23 & 62 & 38 & 123 \\
Espanhol & 694 & 1.206 & 1.464 & 1.760 & 1.655 & 1.165 & 7.944 \\
Esperanto & - & - & - & 14 & 50 & 20 & 84 \\
Francês & 747 & 1.931 & 2.622 & 2.997 & 2.852 & 2.714 & 13.863 \\
Grego Moderno & - & 17 & 6 & 14 & 4 & 14 & 55 \\
Hebraico & 14 & 22 & 24 & 24 & 33 & 37 & 154 \\
Inglês & 1.473 & 3.991 & 5.150 & 6.660 & 7.152 & 7.028 & 31.454 \\
Italiano & 101 & 234 & 315 & 387 & 447 & 464 & 1.948 \\
Japonês & 77 & 210 & 222 & 348 & 250 & 284 & 1.391 \\
Mandarim & 31 & 140 & 219 & 213 & 339 & 254 & 1.196 \\
Russo & 15 & 40 & 64 & 58 & 73 & 101 & 351 \\
Turco & - & - & - & - & 11 & 8 & 19 \\
\hline \multicolumn{1}{c}{ Total } & $\mathbf{3 . 1 8 7}$ & $\mathbf{7 . 9 5 0}$ & $\mathbf{1 0 . 4 5 6}$ & $\mathbf{1 3 . 2 0 9}$ & $\mathbf{1 3 . 8 1 1}$ & $\mathbf{1 3 . 1 5 7}$ & $\mathbf{6 1 . 7 7 0}$
\end{tabular}

Fonte: elaboração própria a partir de dados extraídos do SGI.

A Tabela 8 apresenta a evolução do número de matrículas dos campi Gama, Planaltina e Ceilândia. O campus da Ceilândia, apesar das atividades do Projeto terem sido implantadas apenas no ano de 2013, apresentou desempenho superior ao campus Gama. No que se refere ao número de matrículas realizadas nos cursos de Inglês, campus da Ceilândia, o número de alunos dobrou entre os anos de 2013 e 2014.

Outra percepção refere-se à evolução positiva das matrículas em todos os campi. Não foram analisados os dados de forma a verificar sobre o índice de qualidade dos cursos e, também, sobre a proporção do atendimento da comunidade interna e externa nos campi em referência.

Tabela 8 - Expansão do Projeto de Cursos Abertos Sequenciais de Idiomas para outros campi da UnB - 2012 a 2014

\begin{tabular}{rcccccccccccccc}
\hline \multirow{2}{*}{ Idioma } & \multicolumn{3}{c}{ Campus Gama } & \multicolumn{4}{c}{ Campus Planaltina } & \multicolumn{3}{c}{ Campus Ceilândia } \\
\cline { 2 - 12 } & 2012 & 2013 & 2014 & Total & 2012 & 2013 & 2014 & Total & 2012 & 2013 & 2014 & Total & Total \\
\cline { 2 - 11 } & Alemão & 32 & 66 & 48 & 146 & - & - & - & - & - & 11 & 21 & 32 & $\mathbf{1 7 8}$ \\
Espanhol & 24 & 42 & 19 & 85 & - & 18 & 7 & 25 & - & 37 & 48 & 85 & $\mathbf{1 9 5}$ \\
Francês & 80 & 118 & 80 & 278 & - & 21 & 15 & 36 & - & 18 & 73 & 91 & $\mathbf{4 0 5}$ \\
Japonês & - & - & 16 & 16 & - & - & - & - & - & - & - & - & $\mathbf{1 6}$ \\
Inglês & 433 & 692 & 731 & 1856 & 71 & 305 & 394 & 770 & - & 434 & 992 & 1426 & $\mathbf{4 0 5 2}$ \\
Italiano & - & 9 & - & 9 & - & - & - & - & - & - & - & - & $\mathbf{9}$ \\
Russo & - & 12 & - & 12 & - & - & - & - & - & - & - & - & $\mathbf{1 2}$ \\
\hline Total & $\mathbf{5 6 9}$ & $\mathbf{9 3 9}$ & $\mathbf{8 9 4}$ & $\mathbf{2 4 0 2}$ & $\mathbf{7 1}$ & $\mathbf{3 4 4}$ & $\mathbf{4 1 6}$ & $\mathbf{8 3 1}$ & - & $\mathbf{5 0 0}$ & $\mathbf{1 1 3 4}$ & $\mathbf{1 6 3 4}$ & $\mathbf{4 8 6 7}$ \\
\hline
\end{tabular}

Fonte: elaboração própria a partir de dados extraídos do SGI. 
A partir do ano de 2011, as atividades do Projeto foram implementadas nas instalações do Programa no Edifício Anápolis, localizado no Setor Comercial Sul, para o atendimento da comunidade local daquela região comercial de Brasília. Foram implementados os Cursos abertos sequenciais de Alemão, Espanhol, Francês e Inglês.

Considerando que não houve o lançamento das turmas/cursos de forma individualizada no SGI para aquele ano, optamos por apresentar os dados relativos às matrículas para o período de 2012 a 2014, conforme demonstrado na Tabela 9.

Os dados revelam que houve um total de 2.305 mil matriculas realizadas no período de 2012 a 2014, sendo cerca de 70\% dessa demanda referente ao idioma Inglês. O crescimento do número de matrículas correspondeu a cerca de $250 \%$ com relação ao número de matriculas realizadas no ano de 2012.

Tabela 9 - Evolução do número de matriculas no SCS - 2012 a 2014

\begin{tabular}{rccccc}
\hline \multicolumn{1}{c}{ Idioma } & $\mathbf{2 0 1 2}$ & $\mathbf{2 0 1 3}$ & $\mathbf{2 0 1 4}$ & Total & Matrículas \% \\
\hline Alemão & 5 & 21 & 13 & $\mathbf{3 9}$ & 1,8 \\
Espanhol & 73 & 92 & 156 & $\mathbf{3 2 1}$ & 13,9 \\
Francês & 55 & 88 & 177 & $\mathbf{3 2 0}$ & 13,8 \\
Inglês & 329 & 489 & 807 & $\mathbf{1 . 6 2 5}$ & 70,5 \\
\hline Total & $\mathbf{4 6 2}$ & $\mathbf{6 9 0}$ & $\mathbf{1 . 1 5 3}$ & $\mathbf{2 . 3 0 5}$ & $\mathbf{1 0 0 , 0}$ \\
\hline Fonte: elaboração própria a partir de dados extraídos do SGI.
\end{tabular}

\subsubsection{Atuação das bolsas ofertadas pelo Programa no período de 2009 a 2014}

São destinadas ao sistema de bolsas duas vagas por turma/nível/curso ofertada no período, sendo uma vaga destinada para servidores/professores e uma vaga para estudantes carentes.

A Tabela 10 mostra o total de vagas disponibilizadas, por idioma, à título de bolsas oferecidas para a comunidade interna da Universidade de Brasília, período de 2009 a 2014, e a correspondente taxa de ocupação. O número total de vagas disponibilizadas somou 10.912 com taxa de ocupação de $46 \%$ ou 5.030 vagas de bolsas efetivamente preenchidas. Esse valor responde por 7,3\% da demanda total de matrículas realizadas pelo Programa em todo o período (Gráfico 10).

Os dados analisados identificam que o curso do idioma Inglês apresenta a maior taxa de ocupação, com 54,9\%, seguido pelo Curso do idioma Italiano, com 46\%, e Curso do idioma Espanhol, com 43,9\%. 
Tabela 10 - Oferta de bolsas ofertadas e ocupadas nos Cursos Abertos Sequenciais - 2009 a 2014

\begin{tabular}{rcccc}
\hline \multicolumn{1}{c}{ Idioma } & $\mathbf{N}^{\mathbf{0}}$ de turmas & Oferta de bolsas & Bolsas ocupadas & $\begin{array}{c}\text { Taxa de ocupação } \\
(\mathbf{\%})\end{array}$ \\
\hline Alemão & 218 & 436 & 179 & $\mathbf{4 1 , 0}$ \\
Árabe & 14 & 28 & 6 & $\mathbf{2 1 , 4}$ \\
Coreano & 12 & 24 & 7 & $\mathbf{2 9 , 2}$ \\
Espanhol & 913 & 1.826 & 801 & $\mathbf{4 3 , 9}$ \\
Esperanto & 8 & 16 & 3 & $\mathbf{1 8 , 8}$ \\
Francês & 1.195 & 2.390 & 898 & $\mathbf{3 7 , 6}$ \\
Grego & 13 & 26 & 6 & $\mathbf{2 3 , 1}$ \\
Hebraico & 23 & 46 & 12 & $\mathbf{2 6 , 1}$ \\
Inglês & 2.555 & 5.110 & 2.807 & $\mathbf{5 4 , 9}$ \\
Italiano & 188 & 376 & 173 & $\mathbf{4 6 , 0}$ \\
Japonês & 156 & 312 & 55 & $\mathbf{1 7 , 6}$ \\
Mandarim & 108 & 216 & 66 & $\mathbf{3 0 , 5}$ \\
Russo & 49 & 98 & 13 & $\mathbf{1 3 , 3}$ \\
Turco & 4 & 8 & 3 & $\mathbf{3 7 , 5}$ \\
\hline Total & $\mathbf{5 . 4 5 6}$ & $\mathbf{1 0 . 9 1 2}$ & $\mathbf{5 . 0 2 9}$ & $\mathbf{4 6 , 1}$ \\
\hline
\end{tabular}

Fonte: elaboração própria a partir de dados extraídos do SGI.

Gráfico 10 - Relação de bolsas ofertadas e ocupadas - 2009 a 2014.

- Vagas ofertadas

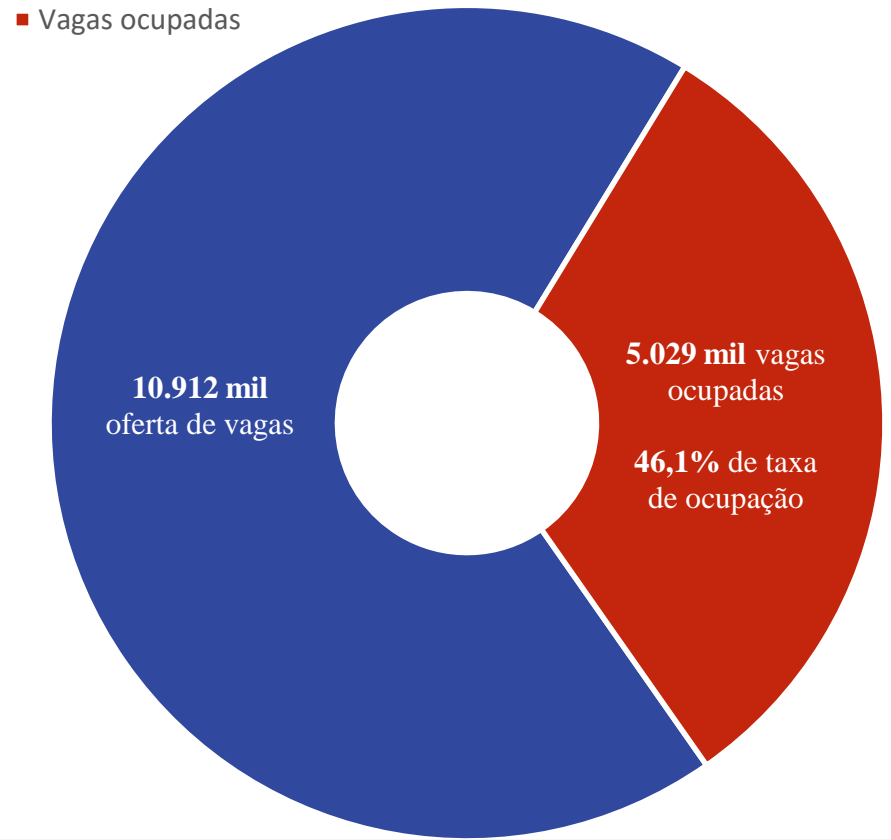

Fonte: elaboração própria a partir de dados extraídos do SGI.

\subsubsection{Estudo de caso para um grupo de alunos do idioma inglês}

$\mathrm{Na}$ intenção de analisar o comportamento de determinado grupo de alunos com relação à sua trajetória e permanência no curso, foi realizado estudo de caso com amostra de 229 alunos matriculados no curso de inglês. A amostra foi extraída aleatoriamente do SGI. 
O grupo é composto de alunos que ingressaram no nível Básico 1 em 2009, e progrediram de forma sequencial nos ciclos que compõem o idioma. Foram considerados para a análise as ofertas regulares $\left(1^{\circ}\right.$ e $2^{\circ}$ semestres ) e ofertas intensivas (inverno e verão).

O Gráfico 11 mostra a evolução desse grupo de alunos no decorrer do processo de conclusão de cada ciclo do idioma. Tem-se ao final do $4^{\circ}$ ciclo (nível Avançado), 5 alunos, ou seja, 2,2\% do grupo concluiu todo o curso. No processo temos que 23,6\% concluiu até $25 \%$ do curso ou até o nível Básico 3, enquanto que 4,8\% concluiu até $50 \%$ e $4 \%$ até $75 \%$ do curso.

\section{Gráfico 11 - Percurso de um grupo de alunos do curso de inglês.}

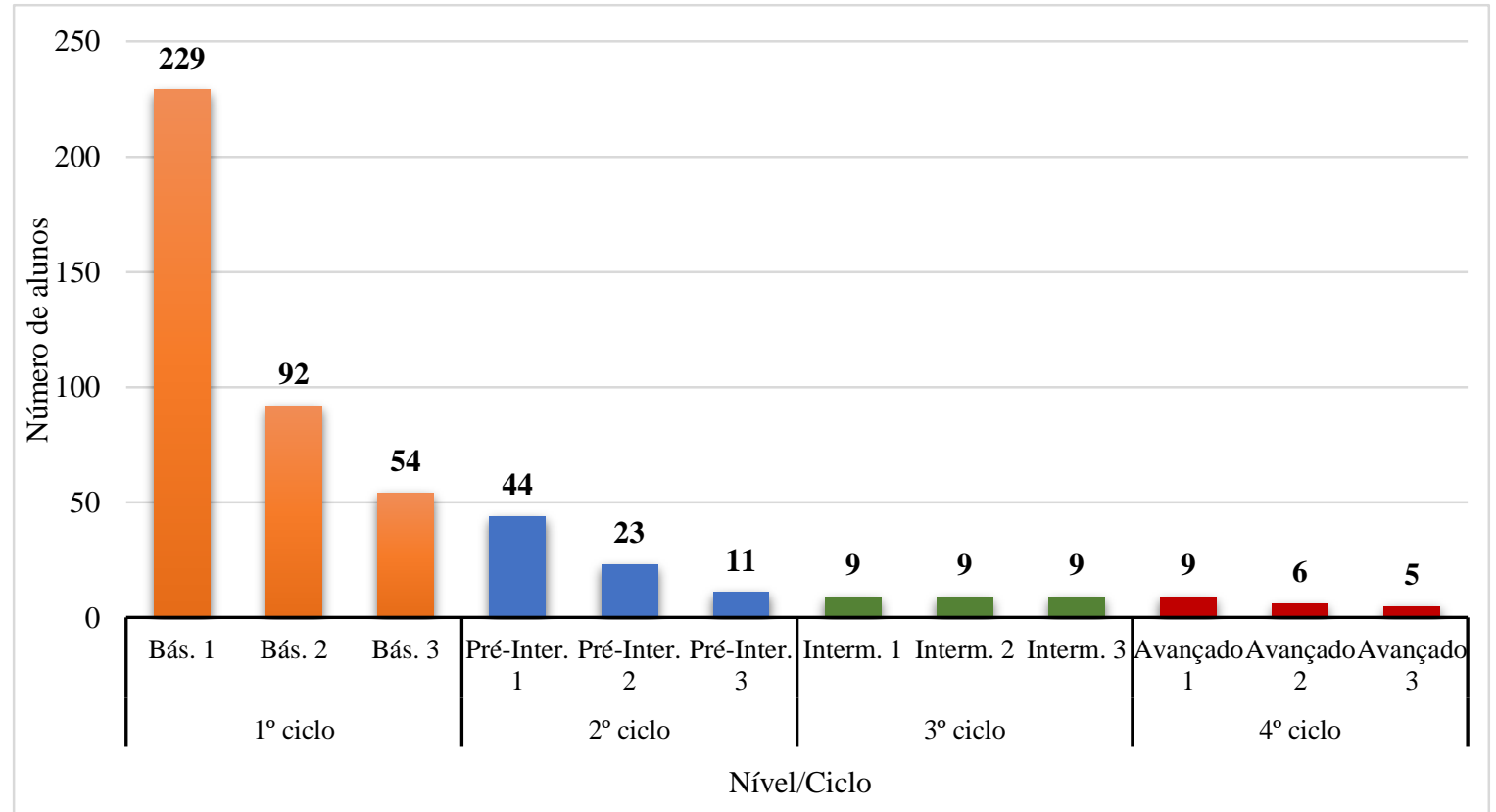

Fonte: elaboração própria a partir de dados do SGI.

\subsubsection{Valores de taxas de matrículas}

Outra informação extraída do SIG refere-se aos valores das taxas de matrículas. Identificou-se que o Projeto pratica valores distintos para essas taxas, diferenciando preços para a Comunidade Interna dos preços para a Comunidade Externa e, ainda, estabelecendo preços para pagamentos à vista (Taxa Única) e preços para pagamentos parcelados. A Tabela 11 apresenta a variação do valor das Taxas no período compreendido entre 2009 a 2014. Foram considerados para esta demonstração somente os valores de Taxas realizadas com pagamentos à vista. 
Tabela 11 - Variação dos valores nominais de taxas de matrículas dos Cursos Abertos Sequenciais de Idiomas.

\begin{tabular}{rcccccc}
\hline \multirow{2}{*}{ Curso/Idioma } & \multicolumn{2}{c}{$\mathbf{2 0 0 9 / 2 0 1 0}$} & \multicolumn{2}{c}{$\mathbf{2 0 1 1}$} & $\mathbf{2 0 1 2 / 2 0 1 3 / 2 0 1 4}$ \\
\cline { 2 - 7 } & Interno & Externo & Interno & Externo & Interno & Externo \\
\cline { 2 - 7 } Espanhol & 200,00 & 270,00 & 295,00 & 405,00 & 325,00 & 445,00 \\
Inglês/Francês & 270,00 & 360,00 & 295,00 & 405,00 & 325,00 & 445,00 \\
Japonês & 200,00 & 270,00 & 295,00 & 405,00 & 325,00 & 445,00 \\
Alemão/Árabe/Italiano/Russo & 420,00 & 480,00 & 445,00 & 540,00 & 485,00 & 585,00 \\
Grego Moderno & 420,00 & 480,00 & 445,00 & 540,00 & 485,00 & 540,00 \\
Esperanto & & & & & 325,00 & 445,00 \\
Coreano & & & & & 485,00 & 585,00 \\
Turco & & & & & 485,00 & 585,00 \\
Mandarim & 420,00 & 480,00 & 420,00 & 480,00 & 460,00 & 540,00 \\
Cursos 3 ${ }^{\mathrm{a}}$. Idade & & & 200,00 & 270,00 & 250,00 & 320,00 \\
\hline
\end{tabular}

Fonte: elaboração própria a partir de dados extraídos do SGI.

Tabela 12 - Valores corrigidos conforme variação do IPCA, considerando pagamento da

Taxa única no mês de janeiro de cada ano - atualizado até janeiro/2015.

\begin{tabular}{|c|c|c|c|c|c|c|c|c|c|c|c|c|}
\hline \multirow{2}{*}{ Idioma } & \multicolumn{2}{|c|}{2009} & \multicolumn{2}{|c|}{2010} & \multicolumn{2}{|c|}{2011} & \multicolumn{2}{|c|}{2012} & \multicolumn{2}{|c|}{2013} & \multicolumn{2}{|c|}{2014} \\
\hline & Interno & Externo & Interno & Externo & Interno & Externo & Interno & Externo & Interno & Externo & Interno & Externo \\
\hline Espanhol & 284,16 & 383,62 & 272,42 & 367,76 & 379,40 & 520,87 & 392,46 & 537,36 & 370,81 & 507,72 & 350,11 & 479,39 \\
\hline Inglês/Francês & 383,62 & 511,50 & 367,76 & 490,35 & 379,40 & 520,87 & 392,46 & 537,36 & 370,81 & 507,72 & 350,11 & 479,39 \\
\hline Japonês & 284,16 & 383,62 & 272,42 & 367,76 & 379,40 & 520,87 & 392,46 & 537,36 & 370,81 & 507,72 & 350,11 & 479,39 \\
\hline Alemão/Árabe & 596,74 & 681,99 & 572,08 & 653,80 & 572,31 & 694,49 & 585,67 & 652,08 & 553,36 & 616,11 & 522,48 & 581,73 \\
\hline Italiano/Russo & 596,74 & 681,99 & 572,08 & 653,80 & 572,31 & 694,49 & 585,67 & 652,08 & 553,36 & 616,11 & 522,48 & 581,73 \\
\hline Grego Moderno & & & 572,08 & 653,80 & 572,31 & 694,49 & 585,67 & 652,08 & 553,36 & 616,11 & 522,48 & 581,73 \\
\hline Esperanto & & & & & & & 392,46 & 537,36 & 370,81 & 507,72 & 350,11 & 479,39 \\
\hline Coreano & & & & & & & 585,67 & 652,08 & 553,39 & 616,11 & 522,48 & 581,73 \\
\hline Turco & & & & & & & 585,67 & 652,08 & 553,39 & 616,11 & 522,48 & 581,73 \\
\hline Mandarim & 596,74 & 681,99 & 573,24 & 655,13 & 538,43 & 615,35 & 555,91 & 652,59 & 523,47 & 614,50 & 495,88 & 582,12 \\
\hline Cursos $3^{a}$ idade & & & & & 256,39 & 346,13 & 302,12 & 386,72 & 284,49 & 364,15 & 269,50 & 344,96 \\
\hline
\end{tabular}

Fonte: elaboração própria a partir de dados da Tabela 11.

Avaliação da eficácia: organização das atividades de cursos; abrangência das ações; cumprimento das metas estabelecidas para o Projeto; relação da extensão com a pós-graduação; impacto na formação do estudante da pós-graduação; produção de cursos e material didático inéditos; atendimento à segmentos específicos da sociedade; atendimento à política de extensão praticada na UnB relativa à concessão de bolsas de estudos.

\subsubsection{Avaliação do Projeto de Cursos corporativos de idiomas}

No ano de 2009, os Cursos corporativos então desenvolvidos pela extinta Escola de Línguas, os quais estavam sendo executados no âmbito dos Contratos assinados pela FUB com outras instituições, foram absorvidos pelo Programa, quando então foi dada organização ao Projeto. Posteriormente, à medida que foram surgindo novos contratos, 
foram sendo desenvolvidos pelos docentes do LET modelos de Cursos de forma a atendêlos. O Quadro 14 apresenta os Cursos atualmente em execução.

Uma das características deste Projeto refere-se a que a elaboração dos Cursos seja feita a partir das demandas apresentadas pelas instituições. Desta forma, constantemente estão sendo elaborados novos modelos de cursos, ou adaptados os existentes, de forma a proporcionar o atendimento aos órgãos contratantes. O Quadro 15 apresenta a relação das instituições contratantes e os cursos realizados no âmbito do respectivo contrato.

\section{Quadro 14 - Objetivo e estrutura dos Cursos Corporativos de Idiomas}

\begin{tabular}{|c|c|c|}
\hline \multicolumn{2}{|r|}{ Idiomas/Cursos } & Estrutura \\
\hline \multicolumn{3}{|c|}{$\begin{array}{l}\text { CURSOS CORPORATIVOS MODELO } 72 \text { HORAS/AULAS/MÓDULOS } \\
\text { Objetivo: }\end{array}$} \\
\hline \multirow{7}{*}{\multicolumn{2}{|c|}{ Alemão, Árabe, Espanhol, Francês, Inglês, Mandarim e Russo }} & Iniciante \\
\hline & & Elementar \\
\hline & & Pré-intermediário \\
\hline & & Intermediário \\
\hline & & Superior \\
\hline & & Avançado \\
\hline & & Conversação \\
\hline \multicolumn{3}{|c|}{$\begin{array}{l}\text { CURSOS CORPORATIVOS MODELO } 54 \text { HORAS/AULAS/MÓDULOS } \\
\text { Objetivo: }\end{array}$} \\
\hline \multirow{9}{*}{\multicolumn{2}{|c|}{ Espanhol, Francês, Inglês }} & Básico 1 \\
\hline & & Básico 2 \\
\hline & & Pré-intermediário 1 \\
\hline & & Pré-intermediário 2 \\
\hline & & Intermediário 1 \\
\hline & & Intermediário 2 \\
\hline & & Avançado 1 \\
\hline & & Avançado 2 \\
\hline & & Conversação \\
\hline \multicolumn{3}{|c|}{ CURSOS COM FINALIDADES ESPECÍFICAS } \\
\hline Idioma & \multicolumn{2}{|c|}{ Curso } \\
\hline Espanhol & \multicolumn{2}{|l|}{ Básico 1 (CHSE) - 30 horas } \\
\hline \multirow{3}{*}{ Inglês } & \multicolumn{2}{|c|}{ Preparação para Apresentação - módulo de 20 horas } \\
\hline & \multicolumn{2}{|l|}{ Negociações - módulo de 20 horas } \\
\hline & \multicolumn{2}{|c|}{ Conversação Orientada - módulo de 40 horas } \\
\hline
\end{tabular}

Fonte: elaboração própria a partir de documentos do UnB Idiomas. 
Quadro 15 - Contratos em execução no âmbito do Projeto.

\begin{tabular}{|c|c|}
\hline Instituições & Cursos/Idiomas \\
\hline \multirow{4}{*}{$\begin{array}{l}\text { Banco Central do Brasil } \\
\text { (Brasília e Regionais BACEN em São } \\
\text { Paulo, Rio de Janeiro; Recife; Bahia; } \\
\text { Belém) }\end{array}$} & Cursos dos Idiomas Inglês e Espanhol - Modelo 54 horas \\
\hline & Curso de Inglês Preparação para Apresentação \\
\hline & Curso de Inglês Negociações \\
\hline & Curso de Conversação Orientada \\
\hline Ministério das Relações Exteriores & $\begin{array}{l}\text { Cursos de Alemão, Árabe, Espanhol, Francês, Mandarim e } \\
\text { Russo - modelo } 72 \text { horas }\end{array}$ \\
\hline Câmara dos Deputados & Cursos de Inglês - 54 horas \\
\hline Ministério do Transportes & Curso de Inglês - 54 horas \\
\hline Ministério do Trabalho e Emprego & Curso de Espanhol e Inglês - modelo 54 horas \\
\hline Estado Maior da Aeronáutica & Curso de Russo - modelo 72 horas \\
\hline Agência Nacional de Águas & Curso de Inglês e Espanhol - modelo 72 horas \\
\hline $\begin{array}{l}\text { Conselho de Corretores de Brasília - } \\
\text { CRECI -DF }\end{array}$ & Cursos de Espanhol e Inglês \\
\hline Associação dos servidores da Infraero & Cursos de Espanhol e Inglês \\
\hline $\begin{array}{l}\text { Sindicato dos Servidores da Policia Civil } \\
\text { do DF }\end{array}$ & Cursos de Inglês \\
\hline
\end{tabular}

Fonte: elaboração própria a partir de documentos do UnB Idiomas.

O segmento do corporativo atendeu um total de 5.905 mil alunos no período de 2009 a 2014, distribuídos principalmente nos cursos das línguas inglesa e espanhola, como poderá ser observado na Tabela 12. O Gráfico 12 apresenta a evolução do número de matrículas desse segmento de curso ao longo do período de 2009 a 2014.

Tabela 13 - Número de alunos atendidos pelos Cursos corporativos de idiomas - 2009 a 2014.

\begin{tabular}{lcccccccc}
\hline Idioma & $\mathbf{2 0 0 9}$ & $\mathbf{2 0 1 0}$ & $\mathbf{2 0 1 1}$ & $\mathbf{2 0 1 2}$ & $\mathbf{2 0 1 3}$ & $\mathbf{2 0 1 4}$ & Total & Matrículas \% \\
\hline Árabe & - & - & 8 & 9 & - & 17 & $\mathbf{3 4}$ & 0,6 \\
Espanhol & 297 & 498 & 464 & 498 & 124 & 528 & $\mathbf{2 . 4 0 9}$ & 40,8 \\
Francês & - & - & 97 & 24 & 58 & 66 & $\mathbf{2 4 5}$ & 4,1 \\
Inglês & 151 & 366 & 1.175 & 537 & 221 & 700 & $\mathbf{3 . 1 5 0}$ & 53,3 \\
Mandarim & - & - & - & 12 & - & 28 & $\mathbf{4 0}$ & 0,7 \\
Russo & - & - & - & - & - & 27 & $\mathbf{2 7}$ & 0,5 \\
\hline Total & $\mathbf{4 4 8}$ & $\mathbf{8 6 4}$ & $\mathbf{1 . 7 4 4}$ & $\mathbf{1 . 0 8 0}$ & $\mathbf{4 0 3}$ & $\mathbf{1 . 3 6 6}$ & $\mathbf{5 . 9 0 5}$ & \\
\hline
\end{tabular}

Fonte: elaboração própria a partir de documentos do UnB Idiomas. 
Gráfico 12 - Evolução do número de alunos em cursos corporativos - 2009 a 2014.

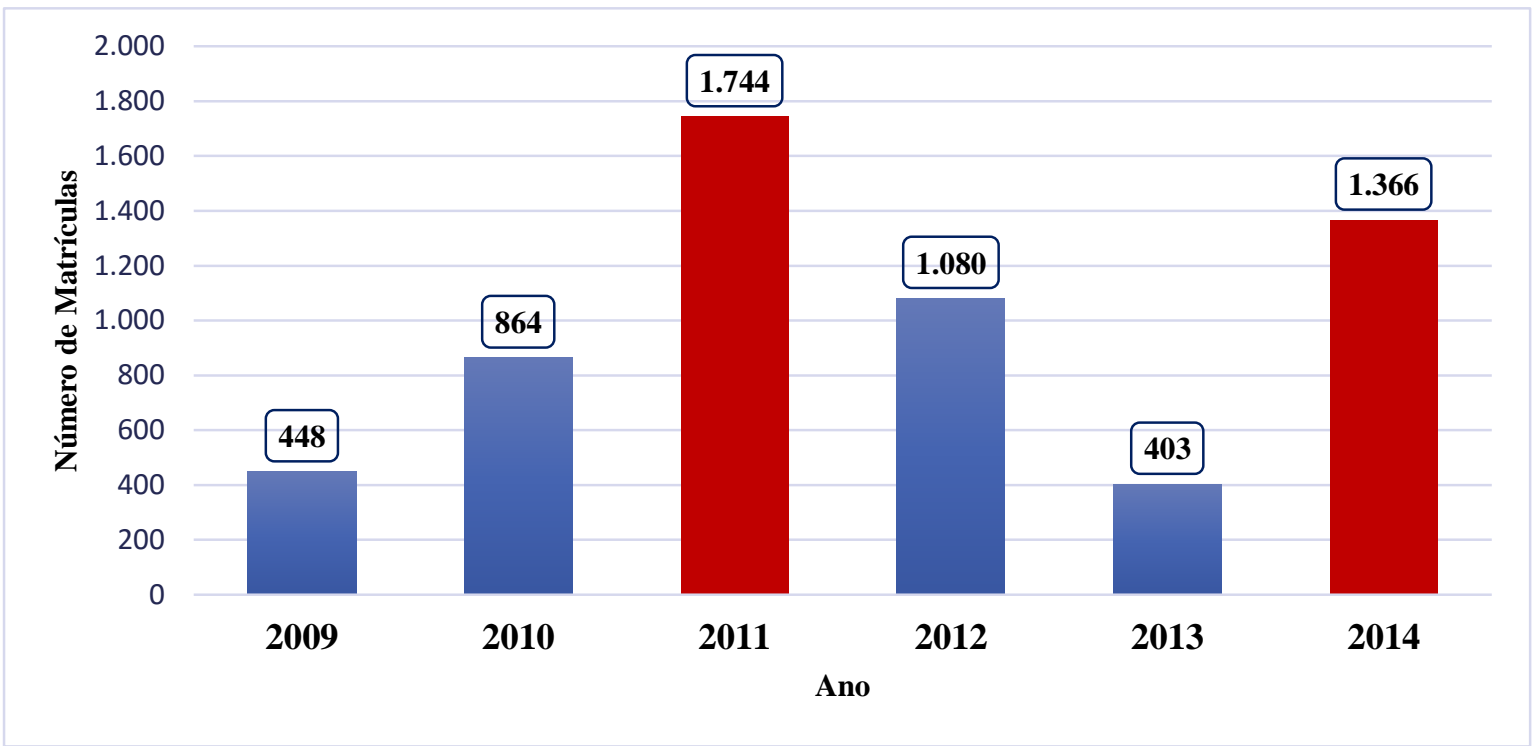

Fonte: elaboração própria a partir de documentos do UnB Idiomas.

Os cursos corporativos seguem o mesmo processo de avalição institucional dos demais cursos, contudo, sua avaliação não é gerada pelo SGI, mas realizada manualmente ao término de cada cursolturma. O Gráfico 13 apresenta a avaliação institucional dos Indicadores de Qualidade por dimensão avaliada, o que engloba todos os idiomas sem diferenciá-los. A avaliação geral dos cursos corporativos obteve um índice de satisfação em torno de $80 \%$, destacando-se a dimensão que mensura o desempenho dos professores, com 96\% de satisfação geral. Outro destaque é a dimensão que avalia a organização pedagógica, com cerca de $88 \%$ de satisfação geral.

O Gráfico 14 apresenta os indicadores de qualidade da avaliação geral de cada um dos idiomas ofertados pelo Projeto no ano de 2014, tendo o Curso de Espanhol obtido a melhor avaliação pelos alunos, com o índice de $92,7 \%$. 
Gráfico 13 - Indicadores de qualidade de avaliação geral - 2014.

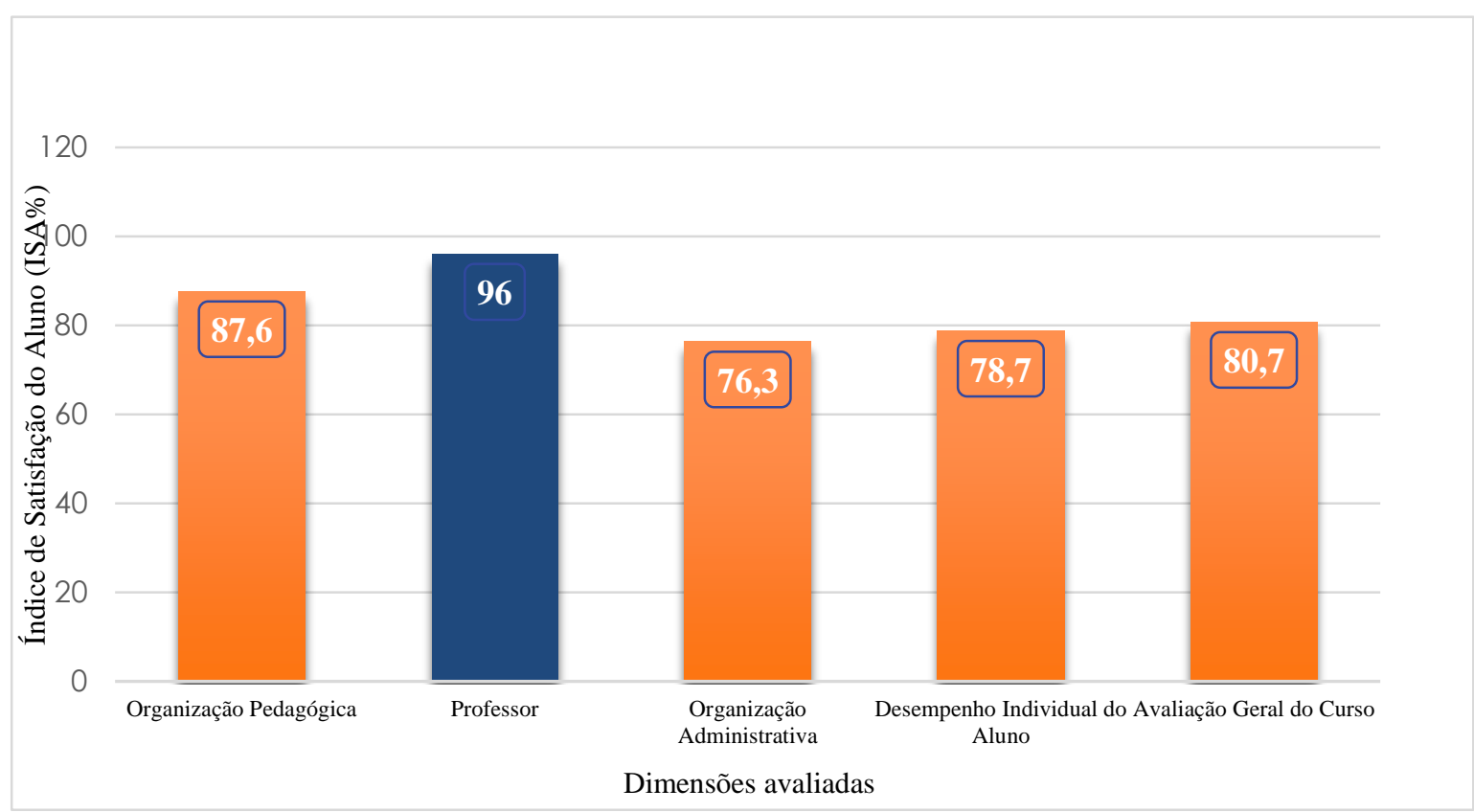

Fonte: elaboração própria a partir de dados extraídos do SGI.

Gráfico 14 - Indicadores de qualidade de cursos por idioma - 2014.

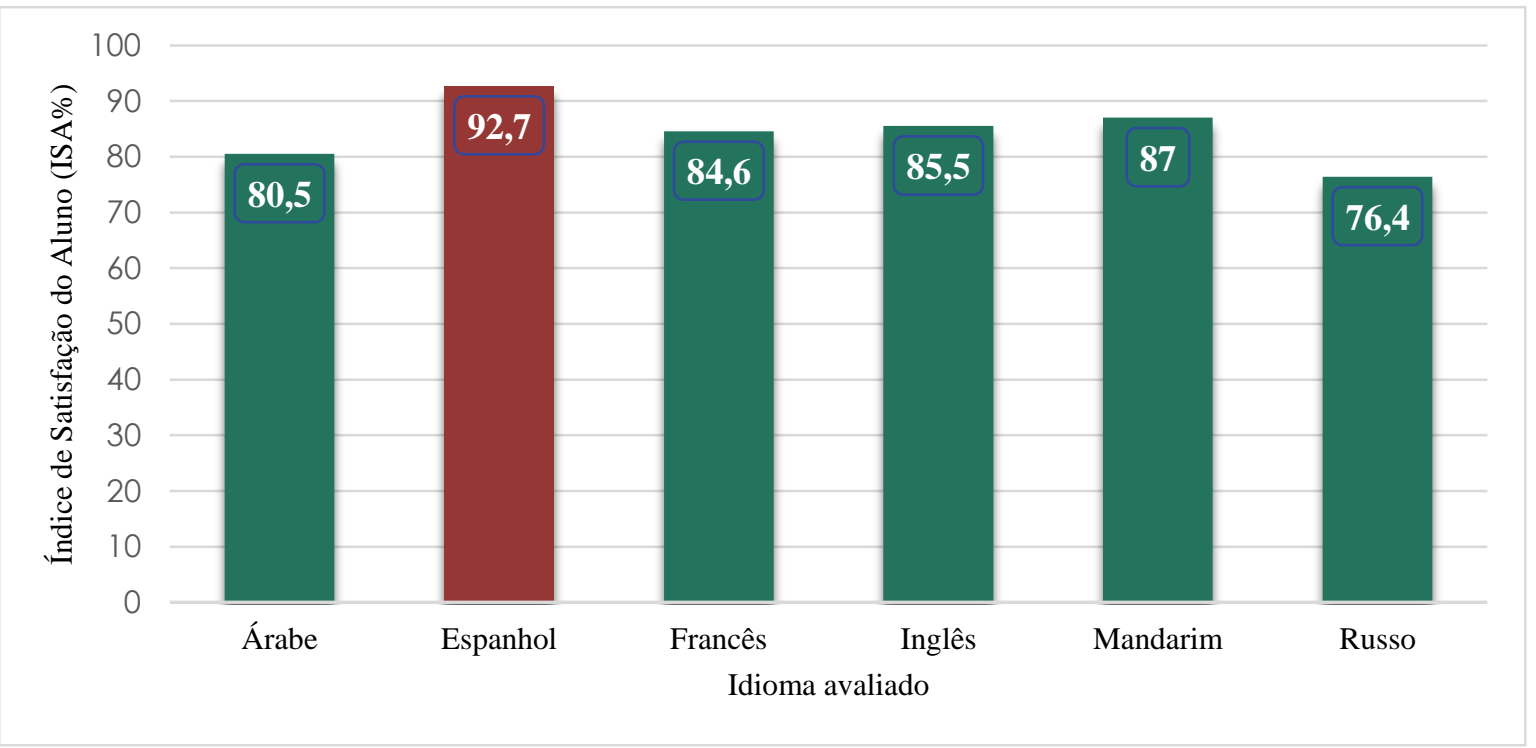

Fonte: elaboração própria a partir de dados extraídos do SGI.

O material didático utilizado para os Cursos é indicado pelo Coordenador do Projeto e avaliado permanentemente pelos professores. Poderão ser usados materiais didáticos adicionais elaborados pelos professores, os quais são disponibilizados por meio de apostilas complementares de estudo.

No caso particular dos cursos do idioma Árabe, Mandarim e Russo o material didático aplicado em sala de aulas é elaborado pelos próprios professores dos cursos, sob 
a avaliação do Coordenador, e disponibilizados para os alunos aprendizes na forma de apostilas. Este material sofre adaptações e inclusões sempre que uma nova estratégia didática para o ensino do idioma é alterada ou incluída.

Avaliação da eficácia: organização do Programa; produção acadêmica; solução de problemas de órgãos públicos no que se refere à comunicação em outros idiomas; atendimento às demandas de setores sociais específicos; cumprimento dos objetivos do Programa.

\subsubsection{Análise financeira do Programa}

O UnB Idiomas arrecadou, no período analisado, uma receita bruta na ordem de R\$ 30.441.041 milhões, proveniente das taxas de matrículas do Projeto de Cursos abertos Sequenciais de Idiomas e dos Contratos realizados no âmbito do Projeto de Cursos Corporativos de Idiomas. Os recursos são depositados integralmente na conta única do Tesouro Nacional e toda a sua execução orçamentária e financeira é realizada pelos Decanato de Administração e Finanças (DAF), por intermédio da sua Diretoria de Contabilidade e Finanças (DCF) e, pelo Decanato de Planejamento e Orçamento (DPO) da UnB. O Gráfico 15 demonstra os valores da arrecadação bruta por ano, considerando o período analisado nesta pesquisa.

\section{Gráfico 15 - Receita Bruta arrecadada e corrigida pelo IPCA ${ }^{1}$ - 2009 a 2014}

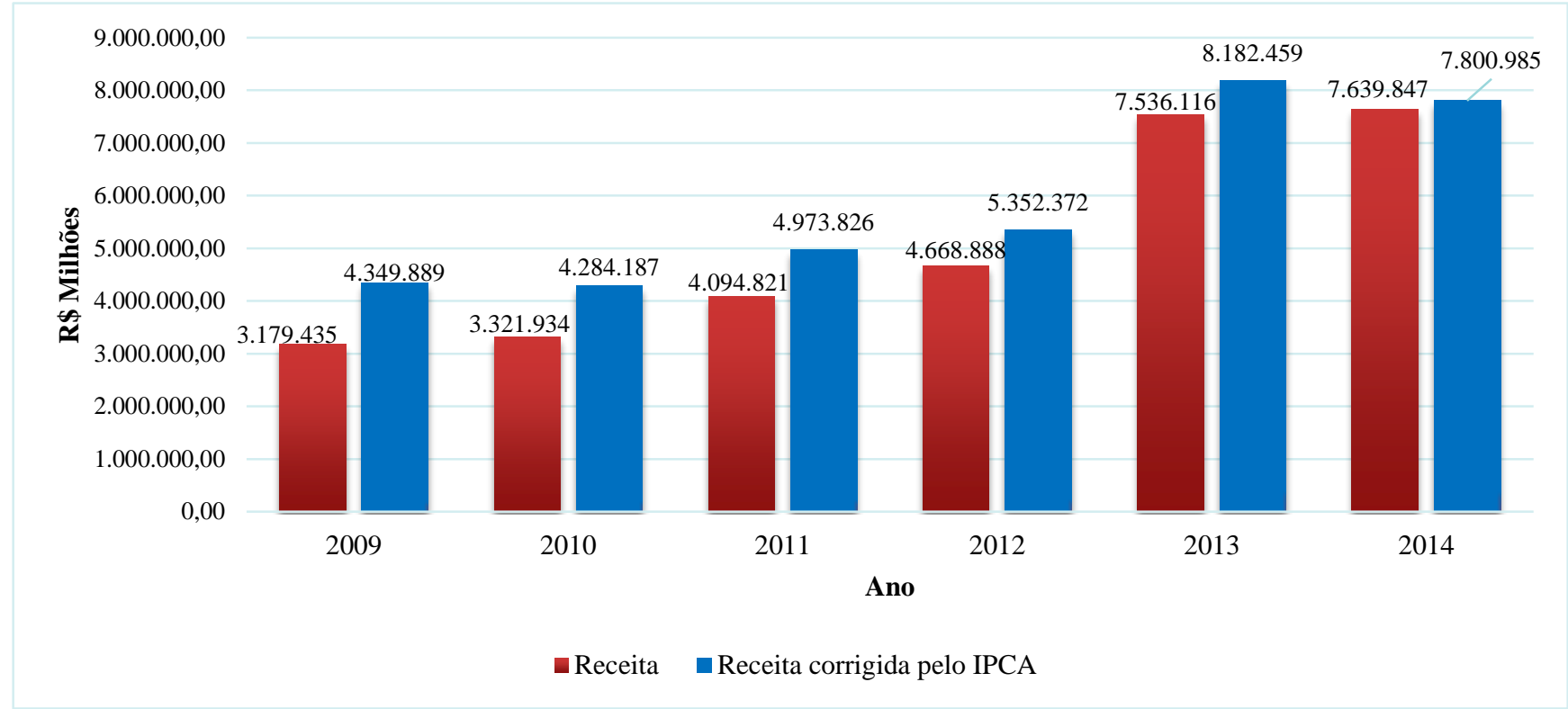

Fonte: elaboração própria a partir de documentos do UnB Idiomas.

(1) Valores atualizados pelo IPCA, considerando o dia 30 de dezembro de cada ano, até janeiro de 2015. 
O Programa cumpre a Resolução do CAD nº 01/2009 no que se refere aos recursos destinados aos custos indiretos do Programa, na ordem de $10 \%$ do valor bruto arrecadado, dos quais 5\% da receita bruta é destinada à Unidade Gestora central (UG) da FUB e, 5\% à unidade acadêmica responsável pelas atividades, neste caso o IL.

Os valores referentes a estes custos indiretos são recolhidos pelo DAF mediante os ingressos dos recursos à conta única do Tesouro Nacional. São demonstrados na Tabela 13 os valores, por exercício, recolhidos à UG da FUB e à unidade IL, considerando o período de 2009 a 2010. Observa-se que o total dos recursos repassados no período compreenderam $\mathrm{R} \$ 3.044 .104$ milhões.

Tabela 14 - Recursos repassados ao DAF e IL à título de custos indiretos - 2009 a 2014.

\begin{tabular}{cccccccc}
\hline Total & $\mathbf{2 0 0 9}$ & $\mathbf{2 0 1 0}$ & $\mathbf{2 0 1 1}$ & $\mathbf{2 0 1 2}$ & $\mathbf{2 0 1 3}$ & $\mathbf{2 0 1 4}$ & Total \\
\hline IL & 158.972 & 166.097 & 204.741 & 233.444 & 376.806 & 381.992 & 1.522 .052 \\
Correção IPCA $^{1}$ & 217.494 & 214.209 & 248.691 & 267.619 & 409.123 & 390.049 & 1.747 .185 \\
FUB & 158.972 & 166.097 & 204.741 & 233.444 & 376.806 & 381.992 & 1.522 .052 \\
Correção IPCA $^{1}$ & 217.494 & 214.209 & 248.691 & 267.619 & 409.123 & 390.049 & 1.747 .185 \\
\hline Total & 317.944 & 332.194 & 409.482 & 466.888 & 753.612 & 763.984 & 3.044 .104 \\
Correção IPCA $^{1}$ & 434.988 & 428.418 & 497.382 & 535.238 & 818.246 & 780.098 & 3.494 .370 \\
\hline
\end{tabular}

Fonte: elaboração própria a partir de dados fornecidos pelo setor financeiro do UnB Idiomas.

(1) Valores corrigidos pelo IPCA, considerando o dia 30 de dezembro de cada ano, até janeiro de 2015.

Também são destinados recursos ao LET na ordem de $10 \%$ do valor bruto ingressado, para o apoio à realização das atividades daquele departamento. O Gráfico16 apresenta os valores anuais repassados ao LET, que compreenderam no período analisado à soma de R \$ 3.044.104 milhões.

\section{Gráfico 16 - Valores repassados ao LET e corrigidos pelo IPCA ${ }^{1}$ - 2009 a 2014.}

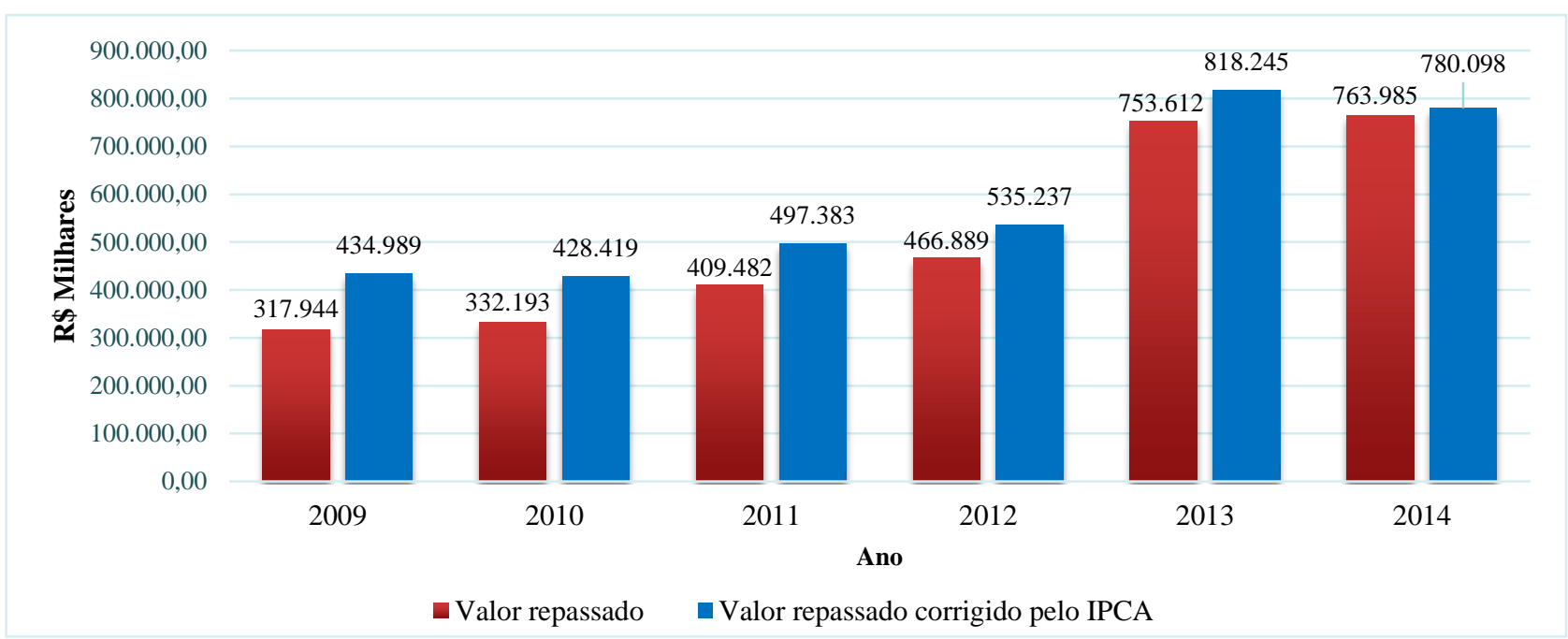

Fonte: elaboração própria a partir de documentos do UnB Idiomas.

(1) Valores corrigidos pelo IPCA, considerando o dia 30 de dezembro de cada ano, até janeiro de 2015. 
O Gráfico 17 demonstra os valores totais repassados à FUB, ao LET e IL, cuja somatório total correspondeu a soma de $\mathrm{R} \$$ 6.088.208 milhões realizados no período de 2009 a 2014.

Gráfico 17 - Valores totais repassados à FUB, IL e LET - 2009 a 2014.

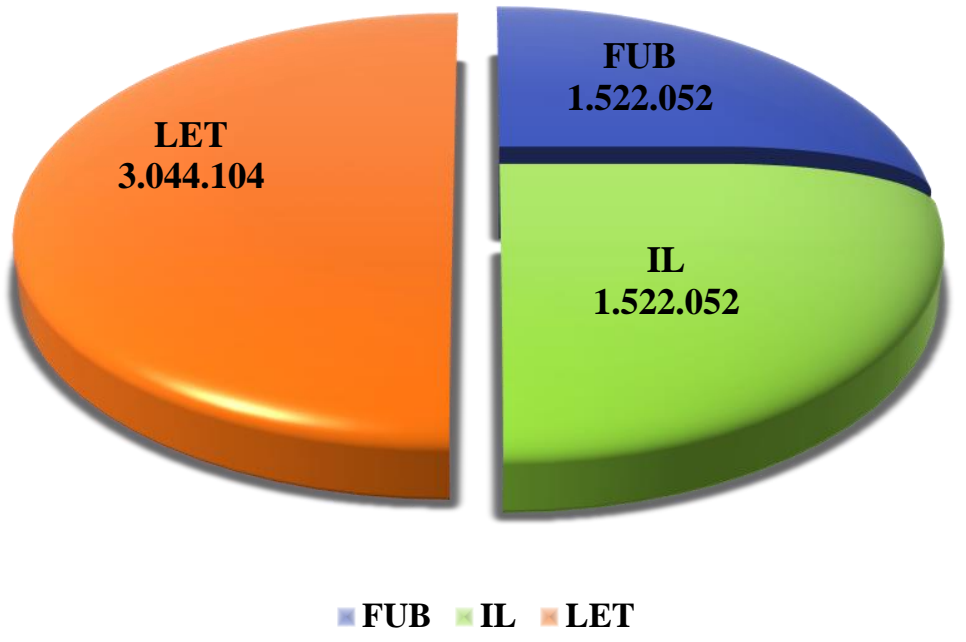

Fonte: elaboração própria a partir de documentos do UnB Idiomas.

O valor líquido arrecadado pelo Programa, correspondente à $80 \%$ do valor bruto arrecadado, ou R\$24.352.833 milões, destinou-se às despesas do Programa e dos seus Projetos, inclusive os gastos realizados com o Projetos de Cursos do estágio supervisionado. O programa apresenta semestralmente a prestação de contas da receita e despesas para o Colegiado do LET.

\subsection{Considerações do Programa à luz das Políticas Extensionista da UnB e do} Brasil.

Neste item apresentamos as análises que realizamos sobre os resultados da pesquisa, obtidos por meio dos dados coletados e apresentados nos itens anteriores desse capítulo. O propósito deste estudo é o de avaliar a eficácia do processo e resultados das ações extensionista realizadas pelo Programa Permanente de Extensão UnB Idiomas, sob o ponto de vista da Política de Extensão da Universidade de Brasília e da Política de extensão hoje praticada no Brasil.

Sob o aspecto da institucionalização do UnB Idiomas como ação extensionista da Universidade, percebe-se o cumprimento dos trâmites requeridos internamente na 
Universidade de Brasília. Na leitura dos documentos do Programa, realizada para esta pesquisa, observa-se que o mesmo recebeu a aprovação, para sua implantação, pelo Colegiado do LET e pelo Conselho do IL. A divulgação dos seus princípios, objetivos e organização foram devidamente publicados à comunidade por meio do seu Regimento, o qual foi aprovado pela Câmara de Extensão do Decanato de Extensão.

O Programa cumpre, desde a sua criação, com os procedimentos obrigatórios no que se refere ao processo de registro e aprovação individual dos Cursos pela CEX, desde os seguintes procedimentos: a) coordenação dos cursos por professores do LET; b) registro no Siex/Interfoco; c) avaliação e aprovação pelo Coordenador de Extensão e colegiado LET; d) aprovação pela CEX/DEX, e) encaminhamentos dos resultados finais de avaliação dos Cursos para o Interfoco; f) validação dos documentos para o processo de certificação dos alunos aprendizes.

Fato importante, refere-se à recomendação da CEX/DEX, no ano de 2013, que as atividades do UnB Idiomas fossem classificadas como Programa de ação contínua, e não mais Curso, na forma como vinha ocorrendo. As atividades realizadas pelo Programa estão inseridas nas seguintes linhas de Extensão definidas pela CEX/DEX: formação de professores; gestão institucional; línguas estrangeiras.

A análise dos dados do Projeto de Cursos do estágio supervisionado indica que desde o ano de 2009 foram viabilizadas as turmas/cursos para atendimento aos 1.014 estudantes das disciplinas da graduação Estágio Supervisionado 1 e 2, que atuam nos cursos como instrutores, contemplando o objetivo do programa no que se refere ao fornecimento de oportunidade diferenciada para que os estudantes de licenciaturas do LET/IL possam desenvolver suas atividades de estágio curricular obrigatório.

Esta realização reafirma, ainda, o aspecto esperado da articulação entre o ensino a extensão, a medida em que estas atividades extensionista interferem positivamente no processo formativo dos estudantes e na dinâmica de organização e funcionamento dos cursos de graduação.

No tocante ao compromisso universitário da indissociabilidade entre o ensino, pesquisa e extensão, o Programa, além das ações relevantes de entrosamento com a graduação, tem possibilitado a participação da Pós-graduação do LET nas atividades extensionistas, como o caso particular dos Cursos com finalidade específicas e Cursos temáticos, realizados no âmbito do Projeto de Cursos abertos sequenciais de idiomas, os quais são realizados a partir de pesquisas desenvolvidas por estudantes e professores da 
pós-graduação sobre novos métodos e/ou abordagens para o ensino aprendizagem de idiomas como línguas estrangeiras.

Nesse aspecto, seria importante uma avaliação mais especifica sobre quais as repercussões efetivas dessa articulação entre ensino, pesquisa e extensão oferecida pelo Programa, tanto no que se refere ao desempenho acadêmico dos atores envolvidos nas atividades extensionistas do Programa, estudantes da graduação e pós-graduação e professores do LET, como também sobre o impacto dessa relação para os projetos acadêmicos e pedagógicos institucionais do LET.

Outra consideração refere-se à relevância social do Programa. Ao analisarmos sobre os dados do Projeto de cursos do estágio supervisionado, percebe-se da oportunidade oferecida para a comunidade interna e externa à universidade de Brasília no aprendizado dos níveis iniciais de línguas estrangeiras, tais como o Espanhol, Francês, Inglês e Japonês de forma gratuita. No período estudado, registrou-se o atendimento de 5.392 alunos/aprendizes matriculados nos cursos do Projeto, sendo que a maioria dessa demanda, um total de 3.423 matrículas, referem-se ao atendimento de alunos dos últimos anos do ensino fundamental, e do ensino médio, da rede de ensino público do Distrito Federal, desde a realização dos Cursos PESES Espanhol Infanto Juvenil.

No caso do Projeto de Cursos abertos sequenciais, esta relevância pode ser percebida pela demanda crescente de matrículas, com um crescimento registrado no ano de 2014 cerca de $2.100 \%$ maior que o número de matrículas realizadas no ano de 2009 , mesmo sendo estes cursos de idiomas disponibilizados para a comunidade interna e externa mediante o pagamento de taxas. Destaca-se que a ocupação dos cursos deste Projeto se dá numa proporção de cerca de $50 \%$ de alunos aprendizes da comunidade interna e $51 \%$ de alunos aprendizes da comunidade externa.

Percebe-se o comprometimento do UnB Idiomas em viabilizar a expansão das atividades do Projeto de Cursos abertos sequenciais de idiomas para outros campi da universidade, o que foi concluído, no ano de 2013, com a implantação dos cursos no campus da UnB na Ceilândia. O número de matrículas realizadas naqueles campi também evidencia a crescente evolução das matrículas no período analisado para esta pesquisa.

Também os cursos de idiomas para a terceira idade expressam essa relevância do Programa para a sociedade, não só do ponto de vista das estratégias didáticas que permitem a inclusão desse público nos cursos por ele realizados, como também pela disseminação desses modelos, como referencial para o mercado convencional de escolas de idiomas de Brasília. Verificou-se que há uma demanda crescente de matrículas também 
para estes cursos, com o registro no ano de 2014 de 739 alunos aprendizes matriculados, cerca de $435 \%$ maior do que o número de matriculas registradas no ano de 2010, quando da implantação dos cursos.

Outro fato que constata a relevância social do Programa, refere-se ao oferecimento de Cursos de Línguas Estrangeiras menos convencionais, como o Mandarim, Russo, Turco e outros, pela oportunidade criada à comunidade interna e externa para o aprendizado desses idiomas, considerando a pouca oferta no mercado de cursos desses idiomas. Não foi dimensionado nesta pesquisa sobre o interesse desses cursos para as necessidades acadêmicas de alunos e professores da comunidade interna, o que melhor validaria sobre a sua relevância como projeto de extensionista.

Neste aspecto, ao avaliarmos sobre o desempenho dos Cursos do idioma alemão, pudemos perceber sobre a expressiva evolução do número de matrículas no período observado, um crescimento de cerca de $585 \%$ se comparadas as matrículas do ano de 2009 com o ano de 2014. Considerando que a ocupação dos cursos se dá numa proporção de $70 \%$ de participação da comunidade interna, infere-se que os estudos desse idioma estejam sendo realizados por interesses acadêmicos, porém esta é uma questão que ainda demanda de investigação mais aprofundada.

Em relação às parcerias verificou-se que a grande maioria dos projetos desenvolvem suas atividades sem parceiros internos, de outros departamentos ou unidades. A única atuação identificada no Programa que conta com a participação de outras unidades acadêmicas da universidade, refere-se ao Instituto Confúcio da UnB, que tem oportunizado a participação de estudantes e professores dessas outras unidades acadêmicas, como o caso do Instituto de Relações Internacionais, em eventos científicos promovidos pelo Instituto. Estas dificuldades apontam para a necessidade do desenvolvimento de estratégias para o fomento dessa articulação interna. Acreditamos que os cursos temáticos, seriam uma boa oportunidade de ver-se envolvidos acadêmicos de outras unidades, oportunizando o ensino de línguas com abordagens de outras áreas de conhecimento, o que seria bastante interessante para aqueles alunos que pretendem realizar os seus estudos de pós-graduação em outras universidades estrangeiras.

Quanto às parcerias externas à Universidade, verificamos que ela se dá, em sua maioria, com órgãos públicos. A elaboração dos cursos se realiza na intenção de atendimento a demanda específicas desses órgãos, o que possibilita aos atores envolvidos no Projeto de Cursos Corporativos a revisão e adequação do material didático e a formulação de novos modelos de cursos a todo momento. Por outro lado, por meio dessa 
interação com esses órgãos públicos o Programa tem disseminado os seus conhecimentos produzidos na intenção de dar solução às demandas de qualificação dos servidores públicos que atuam em órgãos estratégicos de representação governamental em outros países, como se pode constatar na relação apresentada nesta pesquisa dos órgãos contratantes das atividades do Programa.

Do ponto de vista da gestão do Programa, foram adotados os procedimentos gerenciais para a organização das atividades em Projetos, o que deu operacionalidade aos procedimentos logísticos previstos nos objetivos do Programa, e dos Projetos, desde as suas particularidades. A crescente expansão das atividades dos Projetos demonstra que a gestão do UnB Idiomas tem sido muito eficaz neste sentido.

No aspecto da infraestrutura verificou-se que o Programa tem tido dificuldades em ofertar os cursos no campus da asa norte em horários mais flexíveis, isto pelo fato dos cursos serem realizados em salas de aulas da Universidade, em horários disponibilizados pela Prefeitura do campus (PRC), que são, em sua grande maioria, horários de 12h as $14 \mathrm{~h}$. Com isto fica inviabilizado, por exemplo, o atendimento aos estudantes dos cursos de graduação noturnos. Também as instalações do Setor Comercial Sul apresentam dificuldades de infraestrutura no que se refere às poucas salas de aulas para realização dos Cursos. Não há mais capacidade de atendimento nos horários de 12h as 14h e períodos noturnos, horários de maior atendimento à comunidade externa ali atendida.

Verificou-se que o financiamento para a realização das atividades do UnB Idiomas é realizado pela arrecadação feita no âmbito dos Projetos de Cursos Abertos Sequencias e Projeto de Cursos Corporativos. Conforme os dados financeiros levantados para esta pesquisa, do total de recursos ingressados no período de 2009 a 2014, foram destinados $\mathrm{R} \$ 24.353 .833,20$ para este financiamento, um total de $\mathrm{R} \$ 3.044 .104,00$ para os custos indiretos da FUB, dando cumprimento às determinações do $\mathrm{CAD} / \mathrm{UnB}$, e um total de $\mathrm{R} \$$ 3.044.104,00 para o apoio as atividades acadêmicas da graduação e pós-graduação do LET. Não foram levantados nesta pesquisa os tipos e valores dos gastos executados pelo Programa para as suas atividades.

Apesar do Programa produzir relatórios de gestão e prestações de contas semestrais ao Conselho do Programa e ao Colegiado departamental, não existe uma sistemática de avaliação do Programa, e de seus projetos, atrelada às diretrizes gerais da política nacional de avaliação definidas para a extensão por meio do Fórum de PróReitores de Extensão das Universidades Públicas Brasileiras. Desconhece-se sobre as avaliações do UnB Idiomas produzidas pelo Decanato de Extensão, desde as políticas 
extensionista praticadas na UnB, o que talvez decorra da ainda recente recomendação da CEX/DEX para a categorização do UnB Idiomas como Programa de ação continua da Universidade.

A única avaliação praticada pelo UnB Idiomas refere-se à avaliação individual dos Cursos, realizada a partir de questionário de avaliação elaborado pelo Interfoco/DEX, o qual é respondido pelos alunos aprendizes ao final desses cursos e encaminhados para o Interfoco afim de serem processadas as suas informações, isto de forma manual. Considerando a demanda de cursos oferecidos, e o consequente número de alunos aprendizes, o que decorria na demora no envio dos resultados, no ano de 2013 o UnB Idiomas buscou avançar no sentido de fazer com que este questionário fosse aplicado aos alunos por meio eletrônico, criando um banco de dados no SIG, de forma a possibilitar aos Coordenadores dos Projetos, e dos Cursos, uma avaliação mais atualizada dos indicadores de qualidade, com a finalidade de intervir nos processos acadêmicos e administrativos de forma mais eficaz.

Nos contextos investigados, as concepções e práticas extensionista realizadas pelo UnB idiomas apontam para a sua eficácia em muitas das dimensões da política de extensão estabelecida na UnB e na Política extensionista brasileira, ao mesmo tempo em que mostram que há limites a serem superados, como o de aprofundar a articulação entre as três funções da universidade, de buscar viabilizar a interdisciplinaridade, possível na medida das articulações com parceiros internos da universidade, bem como instigar que cada projeto incorpore a dimensão avaliativa, de forma que se possa aprimorar a formação dos estudantes envolvidos e o manejo do seu conhecimento produzido. 


\section{CONSIDERAÇÕES FINAIS}

Na história recente da universidade, constata-se o avanço das suas políticas no sentido de buscar um modelo de produção e transmissão do saber científico de forma a contemplar as diversas demandas requeridas pela sociedade.

Como função universitária, a extensão reveste-se de significados e de conteúdos que a tornam um espaço privilegiado para a aproximação do fazer acadêmico com essas necessidades sociais, ao tempo em que propicia a comunicação acadêmica de diversas áreas de conhecimento, tornando possível potencializar e contribuir para a formulação de políticas públicas. Nesse contexto, a Política Nacional de Extensão Universitária estabelece diretrizes que devem orientar a formulação, implementação e desenvolvimento das ações de extensão universitária, consistidas na indissociabilidade entre a extensão, o ensino e a pesquisa, na busca pela interdisciplinaridade e pela interprofissionalidade, pela formação dos alunos e pela interação dialógica com a sociedade que dela demanda produtos e serviços, com consequente impacto na transformação social decorrente dessa interação.

Nesta dissertação, avaliando-se os documentos normativos da UnB relativos a extensão, pudemos verificar a existência de consonância entre a política extensionista promovida pela Universidade de Brasília e a política extensionista nacional. A UnB é integrante do Fórum de Pró-Reitores de Extensão das Instituições Públicas de Educação Superior Brasileiras (FORPROEX), formulador da Política de Extensão brasileira.

A partir da leitura dos documentos relativos à Política Nacional de Extensão e, ainda, da literatura existente que trata sobre a extensão universitária, foram estabelecidos os indicadores de eficácia de Extensão que deram orientação a esta nossa pesquisa, os quais são apresentados a seguir:

a) Dimensão da Gestão: política, infraestrutura; organização; divulgação; financiamento; resultados obtidos.

b) Dimensão Acadêmica: articulação com o ensino, pesquisa e extensão; interdisciplinaridade; interprofissionalidade; produção acadêmica, relação dialética entre teoria e prática.

c) Dimensão Discente: impacto na formação acadêmica; integralização de créditos obtidos nas ações; ampliação do universo de referência e formação cidadã.

d) Dimensão Social: interação com a sociedade; abrangência; solução de problemas; inclusão; atendimento de demandas da sociedade. 
Ao longo desse estudo, por meio da análise dos dados coletados na pesquisa, foram obtidas evidências dos fatores que contribuem ou dificultam o alcance de eficácia das atividades extensionistas do UnB Idiomas com relação à Política de Extensão da UnB e à Política de Extensão brasileira. Também, o mesmo padrão de análise ofereceu evidências para a verificação da eficácia das atividades extensionistas no que refere aos objetivos traçados pelo Programa.

Desde a dimensão da gestão, o Programa tem sido eficaz no cumprimento da Política e dos aspectos institucionais regulamentares para as atividades de extensão promovidas pela UnB, tanto no que se refere às formalizações relacionadas à aprovação das atividades do Programa junto a CEX/DEX, quanto no gerenciamento dos processos administrativos, logísticos e financeiros, os quais vem sendo realizados de acordo com os padrões estabelecidos pela UnB. A divulgação das atividades do UnB Idiomas é permanentemente vinculada no site criado pelo Programa, e ainda por outros veículos de comunicação próprios da Universidade.

O Programa demonstra estar adequadamente estruturado, com as competências e atribuição dos atores, seus níveis de autoridades e seus procedimentos definidos no seu regimento. Ademais, chama atenção o cuidado do Programa na elaboração de Sistema informatizado, o que lhe possibilitou o gerenciamento dos processos de organização acadêmica dos cursos, o oferecimento de matrícula on line, e a demonstração transparente da gestão dos recursos.

As suas atividades são integralmente financiadas pelos recursos arrecadados no âmbito dos Projetos, sendo este desempenho motivo de permanente prestação de contas financeira e de gestão ao colegiado departamental, tornando pública essas suas ações gerenciais por meio desses documentos.

A estrutura física do Programa está organizada e aparelhada para o atendimento das demandas administrativas. No que se refere às demandas de salas de aulas para a oferta dos cursos constantes do Projeto de cursos abertos sequenciais de idiomas, constata-se dificuldades para o atendimento aos cursos promovidos no campus da Asa Norte, o que tem inviabilizado, por exemplo, a realização de cursos para o atendimento aos alunos dos cursos noturnos e o incremento dos cursos para a $3^{\mathrm{a}}$ idade. O mesmo ocorre para os cursos do Projeto realizados nas salas de aulas das instalações do UnB Idiomas no Setor Comercial Sul, que já está com a sua capacidade saturada, sem possibilidade de aumento na oferta de cursos. Mesmo diante dessa limitação de salas de aulas nestes dois 
locais da UnB, a infraestrutura disponível hoje permite o desempenho eficaz do Programa atualmente ofertado, embora limite sua expansão.

No que se refere à dimensão social do Programa, identificou-se na pesquisa que o Programa vem desenvolvendo as suas atividades de maneira abrangente, dando atendimento às demandas específicas de aprendizagem de línguas estrangeiras tanto para a sua comunidade interna, com a expansão das suas atividades para todos os campi da UnB, como para a comunidade externa à universidade, com o incremento das suas atividades para dar atendimento à comunidade do Distrito Federal, inclusive em regiões comerciais como o Setor Comercial Sul.

Outro aspecto refere-se à promoção de atividades extensionistas que permitem o acesso à Universidade de grupos dela excluídos, como o caso dos Cursos para a terceira idade, que pelo seu modelo inovador acadêmico tornou possível o atendimento a esse público no aprendizado de idiomas. O número crescente de alunos nos cursos da $3^{\mathrm{a}}$ idade, atualmente com 739 alunos matriculados, demonstra a eficácia do Programa nesta sua iniciativa de aproximação da universidade com este segmento da sociedade.

Os dados analisados na pesquisa demonstram a robustez dos resultados das atividades do UnB Idiomas e adequação à proposta expressa em seu regimento, de atendimento à demanda da comunidade interna e externa da UnB e de organizações públicas e privadas, no tocante ao aprendizado de línguas estrangeiras.

Os dados analisados também mostram a eficácia do Programa na dimensão social, com o desenvolvimento de conhecimentos e propostas de solução para o atendimento das necessidade e expectativas da sociedade, conforme preconizado na Política de Extensão da UnB e na Política Nacional de Extensão.

$\mathrm{Na}$ dimensão acadêmica, os dados analisados apresentam os esforços do UnB Idiomas em promover a articulação das suas atividades extensionistas com a graduação e a pós-graduação, o que se percebe, em especial, ao servir como campo de prática para as disciplinas do currículo "Estágio Supervisionado 1 e 2", o que possibilita o enriquecimento da experiência discente em termos teóricos e metodológicos, e para o apoio à realização de cursos elaborados pela Pós-graduação do LET. Percebe-se que esta indissociabilidade graduação-pós-graduação-pesquisa é mais frequente quando os coordenadores do Programa são também professores de disciplinas afins da graduação.

Também a relação com a pesquisa e o ensino se dá a todo momento com a revisão e elaboração de material didático, processo fundamental para a elaboração de novas abordagens didáticas para o ensino de línguas estrangeiras e, ainda, quando da elaboração 
de novos modelos de cursos. Isso ocorre especialmente com aqueles motivados para a prática de teorias de ensino aprendizagem de idiomas propostas pelos alunos e professores da pós-graduação, como o caso dos cursos temáticos, dos cursos da $3^{\mathrm{a}}$ idade e, dos cursos elaborados para atendimento às demandas de órgãos públicos, motivo das relações contratuais realizadas no âmbito do Projeto de Cursos corporativos de idiomas.

Na dimensão acadêmica em particular, o desafio que se impõe para o UnB Idiomas é o de tornar as atividades do Programa mais integradas à vida da unidade acadêmica e de viabilizar a interação de parceiros internos da Universidade, representantes de outras áreas de conhecimento. As possibilidades de integração são grandes e podem ser profícuas, mas dependem de novas redefinições do Programa no que se refere às estratégias para a construção de outras parcerias.

Outro ponto percebido em nossas análises, refere-se aos aspectos de avaliação do Programa, hoje somente estabelecidos nas avaliações dos alunos aprendizes para com as atividades dos Cursos, conforme padrão estabelecido pelo Interfoco/DEX. Essas avaliações atestam a qualidade dos Cursos, nas diversas dimensões avaliadas, o que corrobora a eficácia do Programa conforme percebida pelos participantes dos cursos.

Mormente essa prática avaliativa, o UnB Idiomas ainda não incorporou de forma efetiva a avaliação de suas ações como um todo, numa perspectiva mais participativa entre os coordenadores das atividades extensionistas. Dessa forma, recomenda-se aperfeiçoar o processo avaliativo na intenção de produzir análises sobre os processos de trabalho implementados, os resultados alcançados com esse processo de trabalho, quais os efeitos previstos e não previstos dessas ações na comunidade interna e externa da universidade.

À exceção do processo de avaliação dos cursos propriamente dito, o qual é realizado por meio e formulário próprio do Interfoco/DEX, não identificamos informações sobre métodos e indicadores do DEX para a avaliação dos Programas e Projetos extensionistas promovidos pela UnB. Conforme consta do Plano de Desenvolvimento Institucional (PDI) - 2014 - 2017, a normatização específica da extensão universitária na UnB está em processo de revisão nas unidades acadêmicas. Presumimos, então, que estejam inclusos a previsão e indicadores de avaliação nessa revisão.

Não obstante não haver ainda essas orientações normativas de avaliação do DEX/UnB, é importante que o Programa avance no sentido de promover avaliações permanentes das atividades do Programa como um todo, tendo como referência, para isto, 
as orientações dispostas na Política Nacional de Extensão e outras que puderem ser elaboradas a partir das orientações gerais da Política de Extensão praticada na UnB, e também das suas experiências na realização das atividades. Não temos dúvida de que esse trabalho avaliativo oferecerá contribuições valiosas para a construção da Política de avaliação das ações extensionistas na UnB, ainda em processo de construção.

Finalmente, conclui-se que várias das dimensões da extensão praticada pelo UnB Idiomas estão sendo praticadas de forma eficaz e em consonância com a Política de Extensão praticada na UnB e Política Nacional de Extensão. Não obstante, são importantes alguns avanços no sentido de solidificar este status para a dimensão acadêmica e dimensão avaliativa dos resultados.

Espera-se que esta investigação tenha contribuído para as reflexões sobre a avaliação da eficácia de programas de extensão universitária, visando potencializar as reflexões sobre o próprio Programa e sobre a contribuição destas ações que as universidades se dedicam a fazer.

Compreende-se que a amplitude do tema desta dissertação merece mais estudos e reflexão, dada a complexidade de elementos envolvidos nas diversas abordagens feitas nesta pesquisa. Neste sentido, consideramos tratar-se de uma investigação que merece continuidade e aprofundamento, dado o valor da extensão para a função plena universitária.

Tendo em contexto as várias questões abordadas nesta pesquisa, gostaríamos de encerrar propondo estudos futuros que busquem averiguar sobre até que ponto as atividades extensionistas promovidas pelo UnB Idiomas interferem na constituição da autonomia econômica e social dos alunos aprendizes participantes. Outro ponto relevante e merecedor de estudos futuros refere-se à análise da eficiência econômica do Programa Extensionista, o que pode poderá lançar luzes para o aperfeiçoamento da gestão do UnBIdiomas.

Uma questão também merecedora de estudos futuros refere-se à produção acadêmica decorrente da participação dos atores - alunos da graduação e da pósgraduação, nas atividades promovidas pelos UnB Idiomas. Esta participação pode ter gerado publicações que socializaram alguns dos conhecimentos produzidos nesta experiência, e sem dúvida, caso tenham ocorrido, oferecem maior eficácia para a dimensão acadêmica do Programa, razão pela qual precisa ser este um ponto a ser avaliado. 


\section{REFERÊNCIAS BIBLIOGRÁFICAS}

ARROYO, Daniela M. P.; ROCHA, Maria Silva P. de M. Meta-Avaliação de uma Extensão Universitária: estudo de caso. In: Avaliação. Campinas; Sorocaba, SP, v. 15, n. 2, pp. 135-161, jul., 2010.

BARBOSA, Valeska Cristina. Extensão Universitária: proposição e validação de um instrumento de validação da percepção dos docentes. Belo Horizonte, 2012, 131 f., Dissertação (Mestrado em Administração), Faculdade de Ciências Empresariais, Universidade Fumec.

CABRAL, Nara Grivot. Saberes em Extensão Universitária: contradições, tensões, desafios e desassossegos. Porto Alegre, 2012, 259 f., Tese (Doutorado em Educação), Programa de Pós-graduação em Educação, Universidade Federal do Rio Grande do Sul.

CALDERÓN, Adolfo I. Repensando o papel da universidade. In: RAE - Revista de Administração de Empresas. São Paulo: Fundação Getúlio Vargas, vol. 44, n. 2, pp. 104108, abr./jun., 2004.

CARDOSO, Andreia do Socorro de Sousa. Análise de eficácia e eficiência de políticas públicas voltadas para o desenvolvimento da Amazônia. Belém, 2011, $294 \mathrm{f}$. Tese (Doutorado) - Programa de Pós-Graduação em Desenvolvimento Sustentável do Trópico Úmido, Universidade Federal do Pará, Núcleo de Altos Estudos Amazônicos.

CARNEIRO, António H. O Mundo Mudou: tecnologia e ética. In: Sequeiros, Jorge (org.). Universidade, ciência e sociedade: desafios e fronteiras éticas. Porto: Edição Comissão de Ética da Universidade do Porto, 2014.

COSTA, Helena A.; BURSZTYN, Maria Augusta A.; NASCIMENTO, Elimar P. do. Participação social em processos de avaliação ambiental estratégica. In: Sociedade e Estado. Brasília: Departamento de Sociologia da Universidade de Brasília, v. 24, n. 1, pp. 89-113, jan./abr., 2009.

COTTA, Tereza Cristina. Metodologias de avaliação de programas e projetos sociais: análise de resultados e de impacto. In: Revista do Serviço Público. Brasília: Enap, ano 49, n. 2, pp. 103-124, abr./jun. 1998.

DRÉZE, Jacques; DEBELLE, Jean. Concepções de Universidade. Fortaleza: edições UFC, 1983.

DOURADO, Luiz Fernandes. A reforma do Estado e as políticas para a educação superior no Brasil nos anos 90. In: Educação e Sociedade. Campinas: CEDES/Unicamp, vol. 23, n. 80, pp. 234-252, setembro, 2002.

ELTERMANN, Eddy Ervim. Concepções da universidade: das questões teóricas à representação do senso comum. Santa Catarina, 2012. 115f. Dissertação (Mestrado em Educação), Programa de Pós-Graduação em Educação, Universidade do Sul de Santa Catarina. 
FAGUNDES, Helenara; MOURA, Alessandra Ballinhas. Avaliação de programas e políticas públicas. In: Revista Textos \& Contextos. Porto Alegre: Fundação Getúlio Vargas, v. 8, n.1, pp. 89-103. jan./jun. 2009

FAVA-DE-MORAES, Flávio. Universidade, inovação e impacto socioeconômico. In: São Paulo em perspectiva. São Paulo: Fundação Seade, 14(3), pp. 8-12, 2000.

FÁVERO, Maria de Lourdes de A. A universidade no Brasil: das origens à Reforma Universitária de 1968. In: Educar, Curitiba: editora UFPR, n. 8, pp. 17-36. 2006.

FERNANDES, Pedro Onofre. Economia da Informação. In: Revista Ciência da Informação., Brasília: IBICT, 20(2), pp. 165-168, jul./dez., 1991.

FIGUEIREDO, Marcus Faria; FIGUEIREDO, Argelina Maria C. Avaliação política e avaliação de políticas: um quadro de referências teóricas. In: Análise e Conjunturas. Belo Horizonte: Fundação João Pinheiro, 1 (3), pp.107-127, set./dez. 1986.

FLEXOR, George; LEITE, Sergio Pereira. Análise das Políticas Públicas: breves considerações teórico-metodológicas. In: FATIMA, E. N. et al. (org.). Mundo rural IV: configuração rural-urbana: poderes e políticas. Rio de Janeiro: Mauad, 2007.

FREIRE, Silene de Moraes. Desafios da extensão universitária na contemporaneidade. In: Conexão. Rio de Janeiro: UEPG, v.7, n. 1, pp. 8-15, 2011.

FREY, Klaus. Políticas Públicas: um debate conceitual e reflexões referentes à prática da análise de Políticas Públicas no Brasil. In: Revista Planejamento e Políticas Públicas. Brasília: Ipea, n. 21, pp. 211-259, jun., 2000.

GELINSKI, Carmem Rosário O. G.; SEIBEL, Erni José. Formulação de políticas públicas: questões metodológicas relevantes. In: Revista de Ciências Humanas, Florianópolis: EDUFSC, v. 42, n. 1 e 2, pp. 227-240, abr./out., 2008.

JEZINE, Edineide. As Práticas curriculares e a extensão universitária. In: Anais do $2^{o}$ Congresso Brasileiro de Extensão Universitária. Belo Horizonte:UFMG, Set., 2004.

LOPES, José R. Os caminhos da identidade nas ciências sociais e suas metamorfoses na psicologia social. In: Psicologia e Sociedade. Porto Alegre: UFRGS, 14(1): pp. 7-27; jan. /jun,, 2002.

LOTTA, G. S. Implementação de políticas públicas: o impacto dos fatores relacionais e organizacionais sobre a atuação dos burocratas de nível de rua no Programa Saúde da Família. Tese (Doutorado em Ciência Política). São Paulo, Universidade de São Paulo, 2010. Disponível em: https://www.teses.usp.br/teses/disponiveis/8/.../tde-2010201020342 Acesso em 05/07/2015.

MACIEL, Lucas Ramalho. Política Nacional de Extensão: perspectivas para a universidade brasileira. In: Revista ParticipAção, Brasília: Decanato de Extensão da Universidade de Brasília, Ano 10, n.18, pp. 17-27, dez., 2010. 
MAIA, José Afonso F.; SILVA, Sandra Almeida; Silva, Cristiane Almeida. Metodologia para avaliação econômica e social de políticas públicas. In: Sitientibus, Feira de Santana-BA, n.32, pp.167-192, jan./jun., 2005.

MARTINS, Carlos B. A reforma universitária de 1968 e a abertura para o ensino superior privado no Brasil. In: Educ. Soc. Campinas-SP: CEDES, v. 30, n. 106, pp. 1535, jan. /abr., 2009.

MAZZILLI, Sueli. Ensino, pesquisa e extensão: reconfiguração da universidade brasileira em tempos de redemocratização do Estado. In: RBPAE, Recife: ANPAE, v.27, n. 2, pp. 205-221, mai./ago., 2011.

MENDONÇA, Ana Waleska P. C. A universidade no Brasil. In: Revista Brasileira de Educação. Rio de Janeiro: Anped, n.14, pp. 131-151, mai./jun./jul./ago., 2000.

MOITA, Filomena Maria G. da S.C.; ANDRADE, Fernando C. B. de. Ensino-PesquisaExtensão: um exercício de indissociabilidade na pós-graduação. In: Revista Brasileira de Educação. Rio de Janeiro: Anped, v.14, n. 41, pp. 269-393, mai./ago., 2009.

MORHY, Lauro; CERVO, Amado. L. Universidade em Questão: Universidade no Mundo. Brasília: Editora Universidade de Brasília, 2004. Brasília.

OLIVEIRA, Adão F. de. Políticas públicas educacionais: conceito e contextualização numa perspectiva didática. In: OLIVEIRA, Adão F. de; PIZZIO, Alex; FRANÇA, George (orgs.). Fronteiras da educação: desigualdades, tecnologias e políticas. Goiás: PUC, pp. 93-99, 2010.

PAULA, João Antônio. A extensão universitária: história, conceito e propostas. In: Interfaces. Revista de Extensão da UFMG, Belo Horizonte: UFMG, v.1, n.1, pp. 5-23, jul./nov., 2013.

PEREIRA, Orlando Petiz. Políticas Públicas e Coesão Social. In: Estudios Económicos de Desarollo Internacional. Revista EEDI, v. 5-2, pp. 123-142, jul./dez., 2005. Disponível em http://www.usc.es/economet/eedi.htm Acesso em 01/07/2015.

PINTO, Francisco de P.L. Essa Palavra "Universidade"!. In: Análise Social. Portugal: Universidade de Lisboa, v. 6, n. 20/21, pp. 9-42, 1968. Disponível em http://www.análisesocial.ics.ul.pt Acesso em 15 de março de 2015.

PONTE, Cyntia I. R. Vivas; TORRES, Marco Antônio Rodrigues; MACHADO, Carmen L. Bezerra; MANFRÓI, Carlos Waldomiro. A extensão universitária na Famed/UFRGS: cenário de formação profissional. In: Revista Brasileira de Educação. Porto Alegre: UFRGS, 33(4), pp. 527-534. 2009.

ROCHA, Leilane Aparecida C. Projetos Interdisciplinares de extensão universitária: ações transformadoras. Mogi das Cruzes, 2007. 84 f. Dissertação (Mestrado em Semiótica, Tecnologia de Informação e Educação). Universidade Braz Cuba.

ROURA, Juan R. C. La elaboración de la política económica. In: Introducción a la política económica. Universidad de Alcalá. McGraw-Hill. cap. 4, pp. 99-132, 1997. 
SANO, Hironobu; MONTENEGRO FILHO, Mário Jorge França. As técnicas de avaliação da eficiência, eficácia e efetividade na gestão pública e sua relevância para o desenvolvimento social e das ações públicas. In: Desenvolvimento em questão. IjuíRS: editora Unijuí, ano 11, n.22, pp. 35-61, jan./abr., 2013.

SANTOS, Boaventura de S.; ALMEIDA FILHO, Naomar de. A universidade no século XXI: para uma universidade nova. Coimbra: 2008. Disponível em: http://www.boaventuradesousasantos.pt/media/A\%20Universidade\%20no\%20Seculo\% 20XXI.pdf Acesso em: 22 de abril de 2015.

SANTOS PAULA, Renato Francisco de. Sistêmica único de assistência social no contexto da gestão pública brasileira: fundamentos de gestão. São Paulo: Livrus Negócios Editoriais, vol. 1, 2013.

SERAFIM, Milena Pavan; DIAS, Rafael de Brito. Análise de política: uma revisão da literatura. In: Cadernos Gestão Social. Bahia: UFBA, v. 3, n. 1, pp. 121-134, jan./jun., 2012.

SERRANO, Rossana Maria Souto Maior. Conceitos de extensão universitária: um diálogo com Paulo Freire. In: Rev. FAE. Curitiba, v. 9, n. 19, pp. 59-79, jun./jul., 2008.

SIQUEIRA, Moema Miranda. Eficácia da administração pública: imposição democrática. In: Revista de Administração de Empresas. São Paulo: Fundação Getúlio Vargas, 30(1), pp. 65-72, jan./mar., 1990.

SILVA, Edneilton Gomes. Desempenho institucional: a política de qualificação dos docentes da UESB. Dissertação (Mestrado) - Uneb/ Departamento de Ciências Humanas. Salvador, 2009.

SILVA, Franklin Leopoldo e. Universidade: a ideia e a história. In: Estudos Avançados. São Paulo: IEA-USP,20 (56), pp 191-202, 2006.

SILVA, Jorge Paiva da; OURIQUE, Maiane L. H. A expansão da educação superior no Brasil: um estudo de caso do caso Cesnors. In: Revista Brasileira de Estudos Pedagógicos. Brasília: Inep, v. 93, n. 233, pp. 215-230, jan./abr., 2012.

SILVA, Wanessa de Matos Firmino. Consórcios públicos na gestão de resíduos sólidos urbanos no Brasil. Brasília, 2015, 137 f. Dissertação (Mestrado) - Programa de Pósgraduação em Economia. Universidade de Brasília.

SINGER, Paul. A Universidade no olho do furacão. In: Estudos Avançados. São Paulo: IEA-USP, 15 (42), pp. 305-316, 2001.

SOUZA, Celina. Políticas Públicas: uma revisão da literatura. In: Revista Sociologias. Porto Alegre: UFRGS, ano 8, n. 16, jul./dez., pp. 20-45, 2006.

SOUZA, Lincoln Moraes de. Comentando as classificações de políticas públicas. In: Revista Cronos, Natal-RN: UFRN, v.11, n.1, pp.161-197, jun./jul., 2010. 
ROSA, Wagner de Castro C.; A eficiência de políticas sociais: uma análise teórica da aplicação dos critérios avaliativos no orçamento público. Tese (Doutorado). Programa de Pós-graduação em Políticas Públicas, Estratégias e Desenvolvimento, Universidade Federal do Rio de Janeiro. Rio de Janeiro: UFRJ, 2013.

RUA, Maria das Graças; ROMANINI, Roberta. Tipologia e tipos de políticas públicas. (Unidades IV). IGEPP, [s.d.]. http://igepp.com.br/uploads/ebook/para_aprender_politicas_publicas_-_unidade_04.pdf Acesso em 05/07/2015.

TEIXEIRA, Evilásio. Tradição e Inovação: um desafio para o século XXI. In: Educação. Porto Alegre: Pontifícia Universidade Católica do Rio Grande do Sul, v.32, n. 1, pp. 65-70, jan.-abr., 2009.

TINÔCO, Dinah dos Santos; SOUZA, L. M. de; BARBOSA, Alba de Oliveira. Avaliação de políticas públicas. Modelos tradicional e pluralista. In: Revista Políticas Públicas. São Luís: UFMA, v.15, n.2, pp. 305-313, jul./dez., 2011.

TREVISAN, Andrei Pittol; BELLEN, Hans Michel van. Avaliação de políticas públicas: uma revisão teórica de um campo em construção. In: RAP. Rio de Janeiro: Fundação Getúlio Vargas, 42(3), pp. 529-550, mai./jun., 2008.

TRINDADE, Hélgio. Saber e poder: os dilemas das universidades brasileiras. In: Estudos Avançados. São Paulo: IEA-USP, 14 (40), pp. 122-133, 2000.

VIANA, Ana Luiza. Abordagens metodológicas em políticas públicas. In: RAP. Rio de Janeiro: Fundação Getúlio Vargas, 30 (2): 543, pp. 5-43, mar./abr., 1996.

VIERO, Tatiane V.; TAUCHEN, Gionara. Programa de extensão universitária: análise das concepções e perspectivas no âmbito da Educação em Ciências. Artigo apresentado no IX Anped Sul 2012, Seminário de Pesquisa em Educação da Região Sul, Universidade de Caxias do Sul. jul./ago., 2012. 


\section{APÊNDICE}

Apêndice A - Linhas de Extensão e formas de operacionalização das atividades extensionistas no âmbito da UnB.

\begin{tabular}{|c|c|}
\hline Linhas de Extensão & Formas de Operacionalização das atividades extensionistas \\
\hline $\begin{array}{l}\text { Alfabetização, leitura e } \\
\text { escrita }\end{array}$ & $\begin{array}{l}\text { Alfabetização e letramento de crianças, jovens e adultos; formação do leitor e do produtor de textos; incentivo à leitura; literatura; desenvolvimento de } \\
\text { metodologias de ensino da leitura e da escrita e sua inclusão nos projetos político-pedagógicos das escolas. }\end{array}$ \\
\hline Artes cênicas & $\begin{array}{l}\text { Dança, teatro, técnicas circenses, performance; formação, capacitação e qualificação de pessoas que atuam na área; memória, produção e difusão } \\
\text { cultural e artística. }\end{array}$ \\
\hline Artes integradas & $\begin{array}{l}\text { Ações multiculturais envolvendo as diversas áreas da produção e da prática artística em um único programa integrado; memória, produção e difusão } \\
\text { cultural e artística }\end{array}$ \\
\hline Artes plásticas & Escultura, pintura, desenho, gravura, instalação, apropriação; formação, memória, produção e difusão cultural e artística. \\
\hline Artes visuais & Artes gráficas, fotografia, cinema, vídeo; memória, produção e difusão cultural e artística. \\
\hline $\begin{array}{l}\text { Comunicação } \\
\text { estratégica }\end{array}$ & $\begin{array}{l}\text { Elaboração, implementação e avaliação de planos estratégicos de comunicação; realização de assessorias e consultorias para organizações de naturezas } \\
\text { diversas em atividades de publicidade, propaganda e de relações públicas; suporte de comunicação a programas e projetos de mobilização social, a } \\
\text { organizações governamentais e da sociedade civil. }\end{array}$ \\
\hline $\begin{array}{l}\text { Desenvolvimento de } \\
\text { produtos }\end{array}$ & $\begin{array}{l}\text { Produção de origem animal, vegetal, mineral e laboratorial; manejo, transformação, manipulação, dispensação, conservação e comercialização de } \\
\text { produtos e subprodutos. }\end{array}$ \\
\hline $\begin{array}{l}\text { Desenvolvimento } \\
\text { regional }\end{array}$ & $\begin{array}{l}\text { Elaboração de diagnóstico e de propostas de planejamento regional (urbano e rural), envolvendo práticas destinadas à elaboração de planos diretores, } \\
\text { a soluções, tratamento de problemas e melhoria da qualidade de vida da população local, tendo em vista sua capacidade produtiva e potencial de } \\
\text { incorporação na implementação das ações; participação em fóruns Desenvolvimento Local Integrado e Sustentável - DLIS; participação e assessoria } \\
\text { a conselhos regionais, estaduais e locais de desenvolvimento e a fóruns de municípios e associações afins; elaboração de matrizes e estudos sobre } \\
\text { desenvolvimento regional integrado, tendo como base recursos locais renováveis e práticas sustentáveis; permacultura; definição de indicadores e } \\
\text { métodos de avaliação de desenvolvimento, crescimento e sustentabilidade. }\end{array}$ \\
\hline
\end{tabular}




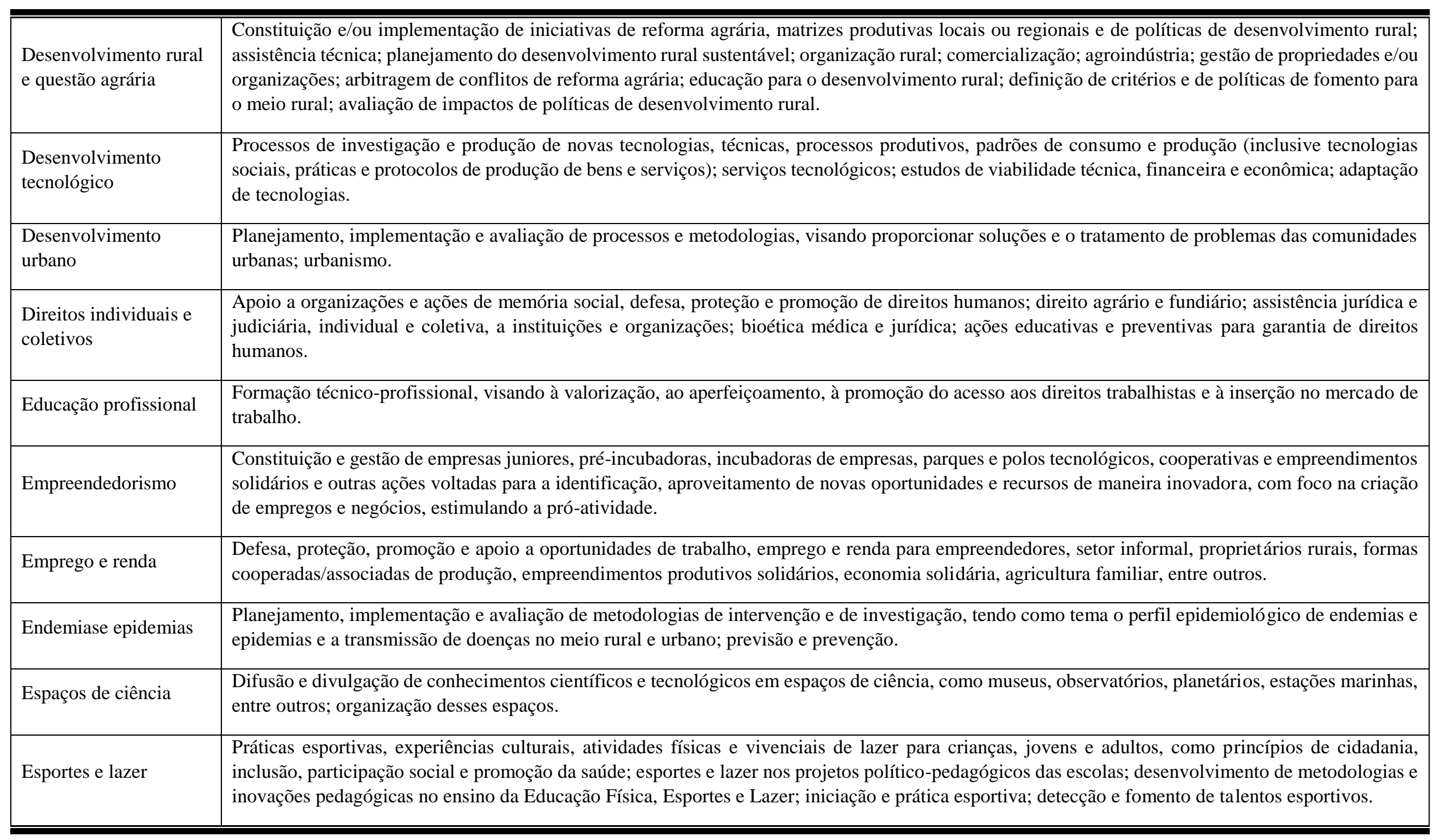




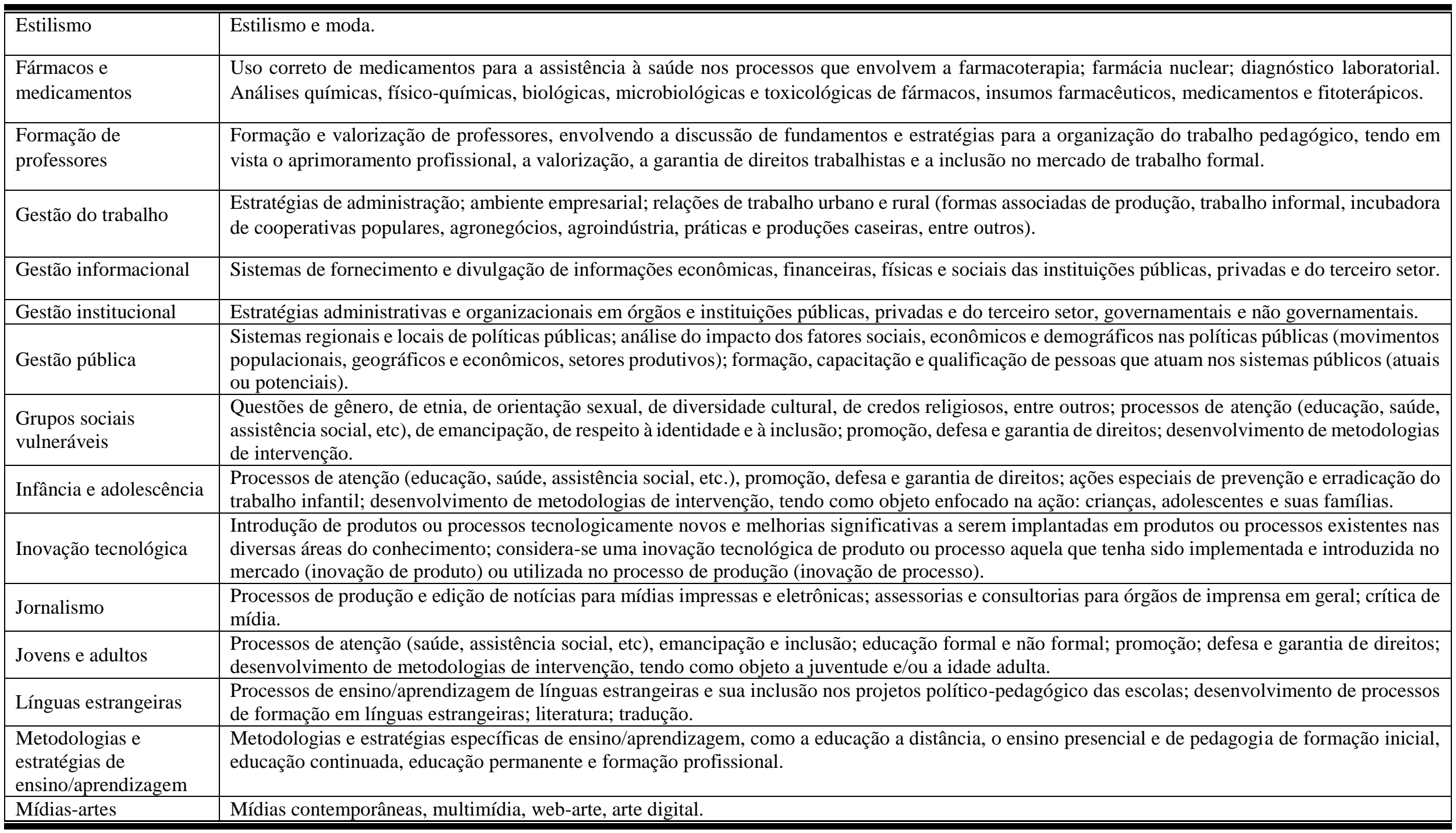




\begin{tabular}{|c|c|}
\hline Mídias & $\begin{array}{l}\text { eículos comunitários e universitários, impressos e eletrônicos (boletins, rádio, televisão, jornal, revistas, internet, etc.); promoção do uso didático dos } \\
\text { eios de educação e de ações educativas das mídias. }\end{array}$ \\
\hline Música & $\begin{array}{l}\text { preciação, criação e performance; formação, capacitação e qualificação de pessoas que atuam na área musical; produção e divulgação de informações, } \\
\text { nhecimentos e material didático na área; memória, produção e difusão cultural e artística }\end{array}$ \\
\hline $\begin{array}{l}\text { Organizações da } \\
\text { sociedade civil e } \\
\text { movimentos sociais e } \\
\text { populares }\end{array}$ & $\begin{array}{l}\text { Apoio à formação, organização e ao desenvolvimento de comitês, fóruns, associações, ONGs, OSCIPs, redes, cooperativas populares, sindicatos, entre } \\
\text { outros. }\end{array}$ \\
\hline $\begin{array}{l}\text { Patrimônio cultural, } \\
\text { histórico, natural e } \\
\text { imaterial }\end{array}$ & $\begin{array}{l}\text { preservação, recuperação, promoção e difusão de patrimônio artístico, cultural e histórico (bens culturais, móveis e imóveis, obras de arte, arquitetura, } \\
\text { espaço urbano, paisagismo, música, literatura, teatro, dança, artesanato, folclore, manifestações religiosas populares), natural (natureza, meio ambiente) } \\
\text { material e imaterial (culinária, costumes do povo), mediante formação, organização, manutenção, ampliação e equipamento de museus bibliotecas, } \\
\text { centros culturais, arquivos e outras organizações culturais, coleções e acervos; restauração de bens móveis e imóveis de reconhecido valor cultural; } \\
\text { proteção e promoção do folclore, do artesanato, das tradiçôes culturais e dos movimentos religiosos populares; valorização do patrimônio; memória, } \\
\text { produção e difusão cultural e artística. }\end{array}$ \\
\hline $\begin{array}{l}\text { Pessoas com } \\
\text { deficiências, } \\
\text { incapacidades, e } \\
\text { necessidades especiais }\end{array}$ & $\begin{array}{l}\text { Processo de atenção (educação, saúde, assistência social, etc.), de emancipação e inclusão de pessoas com deficiências, incapacidades físicas, sensoriais } \\
\text { e mentais, síndromes, doenças crônicas, altas habilidades, entre outras; promoção, defesa e garantia de direitos; desenvolvimento de metodologias de } \\
\text { intervenção individual e coletiva, tendo como objeto enfocado na ação: essas pessoas e suas famílias. }\end{array}$ \\
\hline $\begin{array}{l}\text { Propriedade intelectual } \\
\text { e patente }\end{array}$ & ocesso de identificação, regulação e registro de direitos autorais, propriedade intelectual e patente. \\
\hline Resíduos sólidos & $\begin{array}{l}\text { Orientação para desenvolvimento de ações normativas, operacionais, financeiras e de planejamento com base em critérios sanitários, ambientais e } \\
\text { econômicos para coletar, segregar, tratar e dispor o lixo; orientação para elaboração e desenvolvimento de projetos de planos de gestão integrada de } \\
\text { resíduos sólidos urbanos reaproveitáveis (compostagem e reciclagem), destinação final (aterros sanitários e controladores), e remediação de resíduos } \\
\text { a céu aberto; orientação à organização de catadores de lixo. }\end{array}$ \\
\hline Saúde animal & $\begin{array}{l}\text { Processos e metodologias visando a assistência à saúde animal; prevenção, diagnóstico e tratamento; prestação de serviços institucionais em } \\
\text { laboratórios, clínicas e hospitais veterinários universitários. }\end{array}$ \\
\hline Saú & ciais e metodologias de intervenção para a saúde da família. \\
\hline $\begin{array}{l}\text { Saúde e proteção no } \\
\text { trabalho }\end{array}$ & $\begin{array}{l}\text { Processos assistenciais, metodologias de intervenção, ergonomia, educação para a saúde e vigilância epidemiológica ambiental, tendo como alvo o } \\
\text { ambiente de trabalho e como público os trabalhadores urbanos e rurais; saúde ocupacional. }\end{array}$ \\
\hline
\end{tabular}




\begin{tabular}{|c|c|}
\hline Saúde humana & $\begin{array}{l}\text { moção da saúde das pessoas, famílias e comunidades; humanização dos serviços; prestação de serviços institucionais em ambulatórios, laboratórios, } \\
\text { icas e hospitais universitários; assistência à saúde de pessoas em serviços especializados de diagnóstico, análises clínicas e tratamento; clínicas } \\
\text { ntológicas, de psicologia, entre outras. }\end{array}$ \\
\hline & $\begin{array}{l}\text { centivo à produção de alimentos básicos, auto abastecimento, agricultura urbana, hortas escolares e comunitárias, nutrição, educação para o consumo, } \\
\text { gulação do mercado de alimentos, promoção e defesa do consumo alimentar. }\end{array}$ \\
\hline & $\begin{array}{l}\text { ara identificar, localizar, interpretar, relacionar, analisar, sintetizar, avaliar e comunicar informação } \\
\text { l. }\end{array}$ \\
\hline Terceira idade & $\begin{array}{l}\text { oção, } \\
\text { as. }\end{array}$ \\
\hline Turismo & $\begin{array}{l}\text { Planejamento e implementação do turismo (ecológico, cultural, de lazer, de negócios, religioso, etc.) como setor gerador de emprego e renda; } \\
\text { desenvolvimento de novas tecnologias para avaliações de potencial turístico; produção e divulgação de imagens em acordo com as especificidades } \\
\text { culturais das populações locais }\end{array}$ \\
\hline
\end{tabular}

Fonte: elaboração própria, a partir da Resolução CEX/DEX nº 001, 2012. 
Apêndice B - Regimento Interno. 
Reitor Ivan Marques de Toledo Camargo

Vice-Reitora Sonia Báo

Decano de Pesquisa e Pós-Graduação Jaime Martins de Santana

Decano de Graduação Mauro Luiz Rabelo

Decana de Extensão Thérèse Hofmann G. Rodrigues da

Costa

Decana de Assuntos Comunitários Denise Bontempo

Decano de Planejamento e Orçamento César Augusto Tibúrcio Silva

Decano de Administração Luís Afonso Bermúdez

Decana de Gestão de Pessoas : Gardênia da Silva Abbad

Instituto de Letras

Diretor Enrique Huelva Unterbäumen

Vice-Diretora Rozana Reigota Naves

Coordenador Geral Virgílio Pereira de Almeida

Coordenadora Administrativa : Glória Pacita Fraguas Vásquez Gomes 


\section{UnB IDIOMAS}

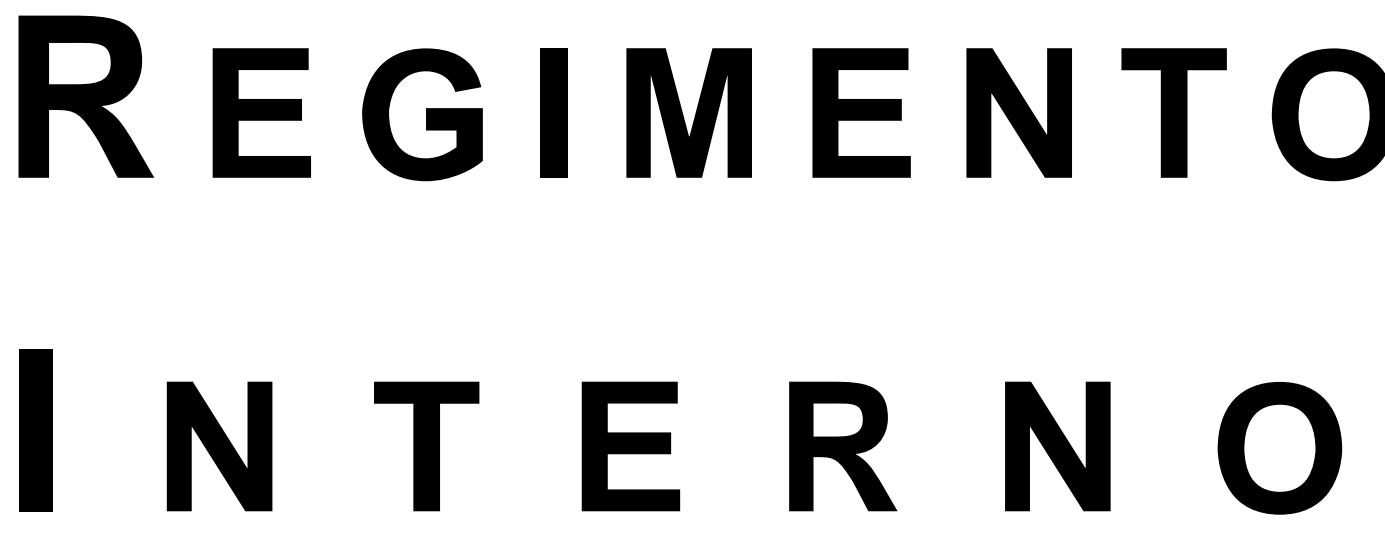

Brasília, 2014

Comissão responsável pela redação final:

Prof. Charles Rocha Teixeira

Profa. Glória Pacita Fraguas Vásquez Gomes

Prof. Hans Theo Harden

Samuel Faria de Abreu

Profa. Tae Suzuki

Prof. Virgílio Pereira de Almeida 


\section{SUMÁRIO}

TÍTULO I - DAS NORMAS GERAIS DO PPEUNB-IDIOMAS.............................................122

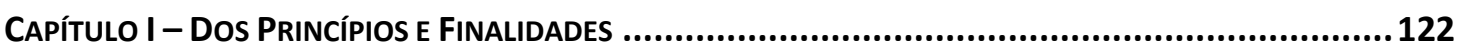

TÍTULO II - DO DEPARTAMENTO DE LÍNGUAS ESTRANGEIRAS E TRADUÇÃO DO INSTITUTO DE

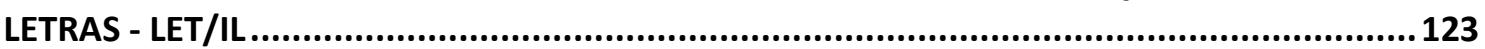

TÍTULO III - DA ESTRUTURA ACADÊMICA, ADMINISTRATIVA E FINANCEIRA DO PPEUNB-

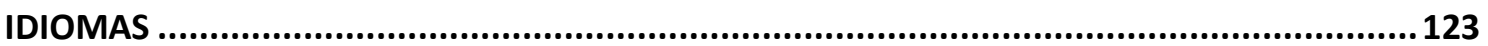

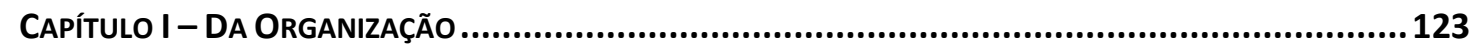

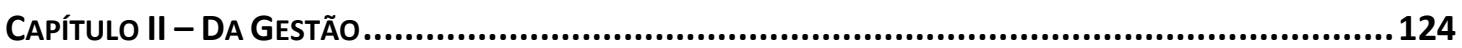

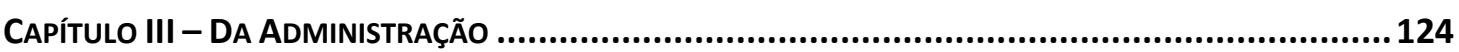

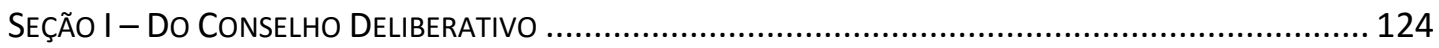

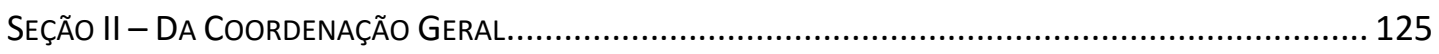

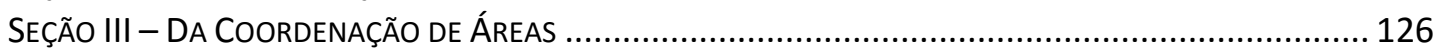

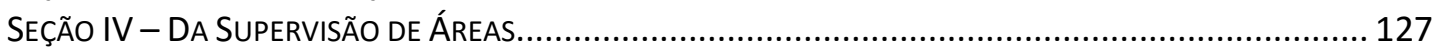

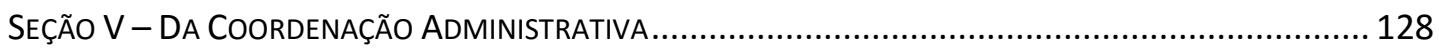

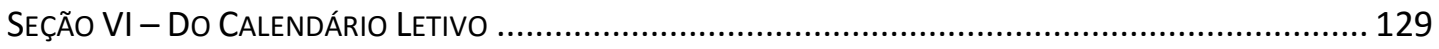

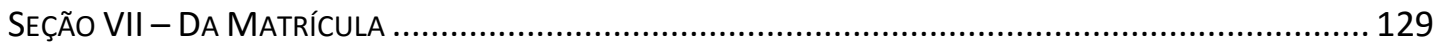

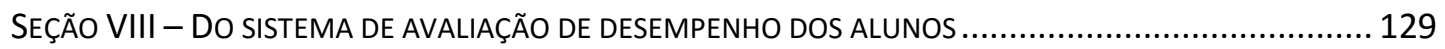

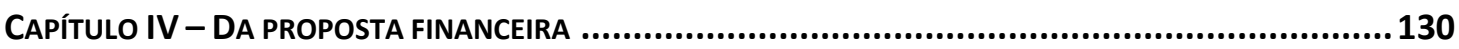

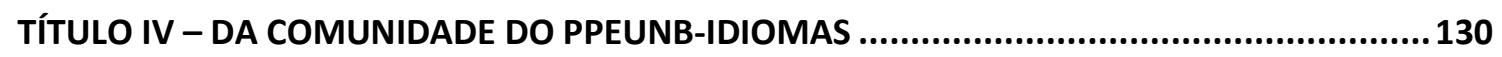

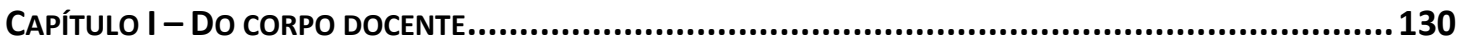

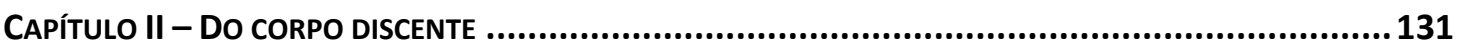

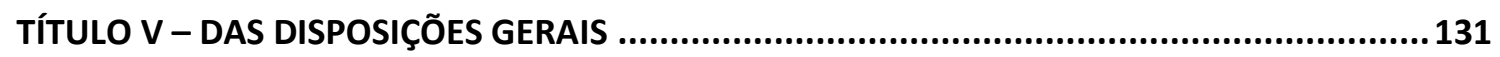




\section{TÍTULO I - DAS NORMAS GERAIS DO PPEUNB-IDIOMAS}

\section{Capítulo I - Dos Princípios e Finalidades}

Art. $1^{\circ}$

Art. $2^{\circ}$

Art. 3ำ

Art. $4^{\circ}$

O PPEUnB-IDIOMAS é um Programa Permanente de Extensão do Departamento de Línguas Estrangeiras e Tradução do Instituto de Letras, doravante LET/LL.

Parágrafo único. O PPEUnB-IDIOMAS rege-se pelo presente Regimento em conformidade com o que estabelece os artigos 54 e 55 do Estatuto da Universidade de Brasília e, subsidiariamente, por normas complementares.

O PPEUnB-IDIOMAS está sob a gestão acadêmica, administrativa e patrimonial do LET/IL.

O PPEUnB-IDIOMAS é um espaço privilegiado para aplicação de pesquisas desenvolvidas, preferencialmente, no Instituto de Letras, particularmente nos programas de pós-graduação e grupos de pesquisas certificados por entidades de fomento à pesquisa.

Parágrafo único. O PPEUnB-IDIOMAS e seus colaboradores deverão oferecer todas as condições para o desenvolvimento de pesquisas em seu espaço, incluindo autorizações para que pesquisadores observem aulas, analisem material didático, apliquem questionários, entre outros.

O PPEUnB-IDIOMAS tem como finalidade essencial atender à crescente demanda das comunidades interna e externa da UnB e de organizações públicas e/ou privadas, relacionadas a línguas.

Art. 5o $\quad$ Entre os serviços oferecidos pelo PPEUnB-IDIOMAS destacamse:

cursos sequenciais de idiomas diversos, de acordo com a demanda de mercado;

cursos corporativos em resposta a demandas específicas de órgãos e/ou empresas públicas ou privadas;

atestação de proficiência em línguas estrangeiras.

Art. 6o O PPEUnB-IDIOMAS organiza e desenvolve suas atividades em conformidade com os seguintes objetivos:

I. estimular, apoiar e incentivar o aprendizado de idiomas;

II. desenvolver sensibilidade intercultural, por meio do ensino de idiomas;

proporcionar aos profissionais da área de Letras programas e eventos de formação continuada e atualização;

auxiliar na realização de programas de educação para professores, com o enfoque na pesquisa em sala de aula; revisar e desenvolver novas metodologias para o ensino de línguas, bem como discutir e sistematizar os procedimentos 
metodológicos utilizados na própria prática do PPEUnBIDIOMAS;

elaborar e aperfeiçoar material didático a ser utilizado em sala de aula;

fornecer oportunidade diferenciada para que os estudantes de licenciaturas do LET/IL possam desenvolver suas atividades de estágio curricular obrigatório.

\section{TíTULO II - DO DEPARTAMENTO DE LÍNGUAS ESTRANGEIRAS E TRADUÇÃO DO INSTITUTO DE LETRAS - LET/IL}

Art. $7^{\circ}$

O LET/IL é o órgão executor do PPEUnB-IDIOMAS, Programa Permanente de Extensão.

Art. 8 $\quad$ Compete ao Colegiado do LET/IL:

I. acompanhar as atividades acadêmicas e administrativas do PPEUnB-IDIOMAS;

gerenciar o processo eletivo para a função de Coordenador Geral e Sub-Coordenador Geral;

gerenciar o processo eletivo para a função de Coordenador Administrativo e Sub-Coordenador Administrativo;

planejar, coordenar e controlar, em conjunto com a Coordenação Geral e a Coordenação Administrativa, a política acadêmica e administrativa do PPEUnB-IDIOMAS;

aprovar os valores das remunerações relativas à prestação de serviços realizados para os projetos do PPEUnB-IDIOMAS propostos pelo Conselho Deliberativo, de acordo com as normas estabelecidas pela FUB/UnB;

receber da Coordenação Geral do PPEUnB-IDIOMAS os projetos dos cursos e/ou eventos de extensão e encaminhá-los às instâncias competentes para aprovação, de acordo com as normas da Câmara de Extensão/DEX;

providenciar a substituição dos Coordenadores e SubCoordenadores Geral e Administrativo que não cumprirem com competência e eficiência as tarefas que lhe forem delegadas; aprovar a prestação semestral de contas do PPEUnB-IDIOMAS.

\section{TÍTULO III - DA ESTRUTURA ACADÊMICA, ADMINISTRATIVA E FINANCEIRA DO PPEUNB-IDIOMAS}

\section{Capítulo I - Da Organização}

Art. 9o $\quad$ O PPEUnB-IDIOMAS observará os princípios de gestão acadêmica, administrativa e financeira conforme estabelece este Regimento e normas internas da UnB. 
Art. 10. O PPEUnB-IDIOMAS está estruturado da seguinte forma:

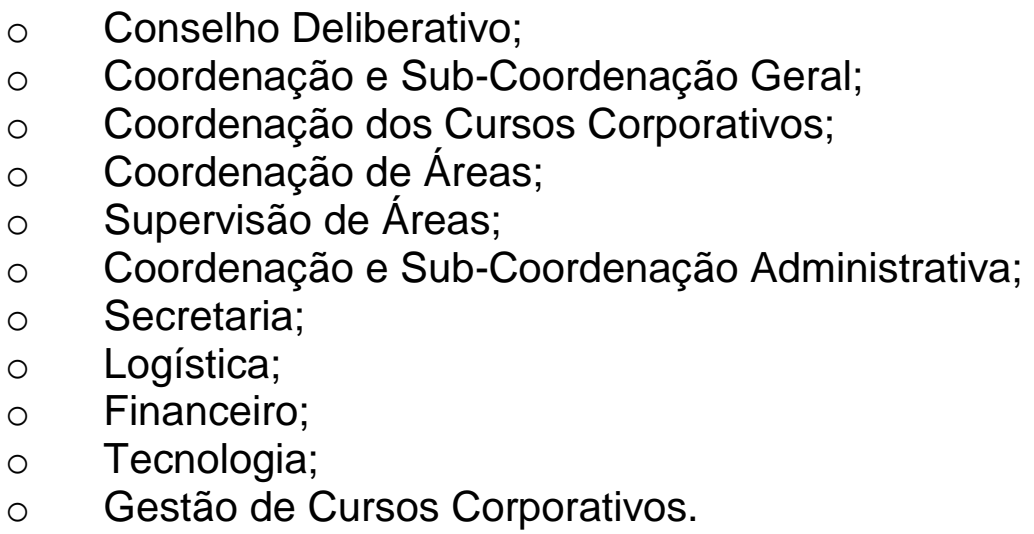

\section{Capítulo II - Da Gestão}

Art. 11. O PPEUnB-IDIOMAS observará, em todas as instâncias deliberativas, os seguintes princípios:

I. publicidade e transparência dos atos e das informações; planejamento e avaliação periódica das atividades; prestação de contas acadêmica e financeira; maioria simples para o funcionamento do conselho deliberativo; condições de manutenção e de perda do direito de representação.

Art. 12. As funções sujeitas ao princípio eletivo estabelecidas nos itens III e IV do Art. 8o têm mandato de dois anos, permitida uma única recondução, excetuados mandatos previstos em lei.

\section{Capítulo III - Da Administração}

Art. 13. A administração do PPEUnB-IDIOMAS tem como órgão deliberativo, normativo e consultivo o Conselho Deliberativo do PPEUnB-IDIOMAS.

\section{Seção I - Do Conselho Deliberativo}

Art. 14. Integram o Conselho Deliberativo do PPEUnB-IDIOMAS:

I. O Chefe do Departamento do LET/IL, como presidente;

O Coordenador Geral do PPEUnB-IDIOMAS, como vicepresidente;

O Coordenador Administrativo do PPEUnB-IDIOMAS;

Os Coordenadores das áreas de espanhol, francês, inglês, japonês, NEPPE e outras línguas;

O Coordenador dos Cursos Corporativos;

Um representante do corpo discente do LET/IL.

Art. 15. O Conselho Deliberativo do PPEUnB-IDIOMAS tem por atribuições: 
I. elaborar e aprovar estratégias e políticas globais do PPEUnB-IDIOMAS;

aprovar as propostas de política de preços e aplicação de recursos, apresentadas pela Coordenação Administrativa;

apresentar propostas de alteração nos vencimentos das funções remuneradas do UnB-IDIOMAS;

Parágrafo único. Qualquer alteração nos vencimentos das funções remuneradas do UnB-IDIOMAS só será efetivada após aprovação pelo Colegiado do LET/IL;

aprovar a prestação semestral de contas do PPEUnB-IDIOMAS.

\section{Seção II - Da Coordenação Geral}

Art. 16.

Integram a Coordenação Geral do PPEUnB-IDIOMAS o Coordenador Geral e o Sub-Coordenador Geral.

Art. 17. O Coordenador Geral do PPEUnB-IDIOMAS e seu SubCoordenador são eleitos pelo Colegiado do LET/IL e aprovados pelo Conselho do Instituto de Letras.

Parágrafo único. O Coordenador Geral do PPEUnB-IDIOMAS e seu Sub-Coordenador deverão ser professores do quadro efetivo, lotados no LET/IL, e exercerão a função por 02 (dois) anos, podendo ser reconduzidos à função por igual período.

Art. 18. O Coordenador Geral do PPEUnB-IDIOMAS terá as seguintes atribuições:

I. planejar, coordenar e controlar, em conjunto com os coordenadores de área concernentes, a organização acadêmica do PPEUnB-IDIOMAS;

elaborar, em conjunto com as respectivas áreas do LET/IL, os projetos de atividades de extensão e encaminhá-los às instâncias competentes para aprovação de acordo com as normas da Câmara de Extensão/DEX;

aprovar a seleção dos professores do PPEUnB-IDIOMAS feita pelas Coordenações de Áreas através de edital simplificado;

zelar pelo cumprimento dos programas dos cursos dentro do calendário escolar;

aprovar, em conjunto com as Coordenações de Áreas do PPEUnB-IDIOMAS, o calendário escolar semestral e anual;

realizar, periodicamente, reunião com os Coordenadores de Áreas para acompanhar as atividades afins;

atuar em conjunto com a Coordenação Administrativa do PPEUnB-IDIOMAS no atendimento às demandas da gestão e do corpo docente;

supervisionar e avaliar a atuação das Coordenações de Áreas; participar de reuniões externas visando à elaboração de cursos específicos para atender à demanda corporativa;

atender às solicitações de ordem acadêmica e pedagógica e realizar os demais trabalhos necessários para melhor execução dos serviços sob sua responsabilidade; 
Art. 19.

definir as formas de avaliação docente em conjunto com as Coordenações de Áreas;

definir as formas de avalição discente em conjunto com as Coordenações de Áreas;

estimular e viabilizar a oferta de cursos de formação continuada para o corpo docente do PPEUnB-IDIOMAS.

O Sub-Coordenador Geral do PPEUnB-IDIOMAS terá a atribuição de substituir o Coordenador Geral nas suas faltas e impedimentos.

\section{Seção III - Da Coordenação de Áreas}

Art. 20.

As respectivas áreas do LET/IL deverão indicar, por meio de documento escrito, um docente para exercer a função de Coordenação de Área no PPEUnB-IDIOMAS, após aprovação no Colegiado do LET/LL.

$\S 1^{\circ} \quad$ Entende-se por 'área' o grupo de professores do LET/IL que trabalham com uma determinada língua, como previsto no Regimento do LET/IL.

$\S 2^{\circ} \quad$ Os Coordenadores de Área exercerão a função por um período de dois anos, podendo ser reconduzidos à função apenas uma vez.

Art. 21. Os coordenadores de áreas deverão ser escolhidos, preferencialmente, do quadro de professores efetivos da FUB, lotados no LET.

$\S 1^{\circ} \quad$ Na hipótese de o coordenador de área não ser do quadro da FUB, este deverá ter experiência em sala de aula e ser do quadro de professores do PPEUnBIDIOMAS, e a sua indicação deverá ser justificada.

$\S 2^{\circ} \quad$ Na hipótese de indicação de um coordenador de uma língua não contemplada nas áreas do LET/LL, caberá tal indicação ao Coordenador de outras línguas em conjunto com o Coordenador Geral.

Art. 22. Os Coordenadores de Áreas estão subordinados diretamente e serão supervisionados e avaliados pela Coordenação Geral do PPEUnB-IDIOMAS.

Art. 23. Compete às Coordenações de Áreas:

I. selecionar o(s) supervisor(es) de área;

II. coordenar a seleção de professores via edital simplificado juntamente com a Supervisão de Área;

III. aprovar o calendário anual (incluindo testes de nível) e questionários de avaliação dos cursos e tabulação dos resultados;

organizar eventos de cunho acadêmico e cultural;

acompanhar as turmas (inclusive com observação de aulas), tirar dúvidas, propor atividades extras como palestras, filmes, festivais etc.; 
orientar os professores;

aprovar os relatórios finais de conclusão de cursos;

receber as menções e relatórios das turmas sob sua coordenação ao final do semestre e encaminhá-las à Coordenação Geral no prazo estabelecido;

selecionar, em conjunto com as respectivas áreas do LET, a metodologia/material didático a ser adotado;

indicar e/ou elaborar o material didático necessário para a execução do curso, observando sua atualização;

apresentar às respectivas áreas do LET, para sua aprovação, o material didático atualizado a ser adotado;

zelar pelo cumprimento rigoroso do calendário letivo;

avaliar sistematicamente os professores sob sua coordenação em conjunto com a Supervisão de Área;

realizar reuniões periódicas com os professores de sua área, com o objetivo de orientar o trabalho a ser desenvolvido;

desempenhar os demais trabalhos que the forem designados pela Coordenação Geral, atinentes à sua área de atuação.

\section{Seção IV - Da Supervisão de Áreas}

Art. 24.

O Supervisor de cada uma das áreas do PPEUnB-IDIOMAS deverá ser selecionado pelo Coordenador da respectiva área, preferencialmente entre os professores do quadro docente do PPEUnB-IDIOMAS, e aprovado pelo Coordenador Geral.

$\S 1^{0} \quad$ O supervisor deverá ter formação acadêmica na área de ensino de línguas.

Art. 25. A carga horária de supervisão será calculada proporcionalmente em relação à média de estudantes, turmas e professores em três semestres consecutivos ao semestre vigente. O número de horas será definido pelo Coordenador Geral junto aos coordenadores de área e aprovado pelo Conselho Deliberativo.

Art. 26. Os supervisores estão subordinados diretamente à Coordenação de Área do PPEUnB-IDIOMAS, que os avalia e coordena.

Art. 27. Compete às Supervisões de Área:

I. participar da seleção de professores em conjunto com a Coordenação de Área;

elaborar calendários anuais (inclusive de testes de nível) e questionários de avaliação dos cursos, incluindo a tabulação dos resultados;

supervisionar a aplicação de testes de nível (incluindo a alocação de professores para aplicar os testes) e questionários de avaliação de curso;

acompanhar as turmas, observar aulas, tirar dúvidas, propor atividades extras;

orientar os professores; 
elaborar programas dos cursos e entregá-los aos professores no início do semestre letivo;

II. acompanhar a execução do conteúdo programático;

III. receber as menções das turmas sob sua supervisão ao final do semestre;

IV. elaborar relatório, observando as normas do DEX, contendo um resumo das ocorrências pertinentes das turmas sob sua supervisão (reclamações, problemas específicos de cada professor, entre outros) e encaminhá-lo à Coordenação de Área no prazo estabelecido;

V. zelar pelo cumprimento rigoroso do calendário letivo;

VI. avaliar sistematicamente os professores sob sua supervisão em conjunto com a Coordenação de Área;

VII. realizar reuniões periódicas com os professores de sua área, com o objetivo de orientar o trabalho a ser desenvolvido; VIII. desempenhar os demais trabalhos que lhe forem designados pela Coordenação de Área, atinentes à sua área de atuação.

\section{Seção V - Da Coordenação Administrativa}

Art. 28.

Integram a Coordenação Administrativa do PPEUnB-IDIOMAS o Coordenador Administrativo e o seu Sub-Coordenador.

Art. 29. O Coordenador Administrativo do PPEUnB-IDIOMAS e seu SubCoordenador serão eleitos pelo Colegiado do LET/LL e aprovados pelo Conselho do Instituto de Letras.

Parágrafo único. O Coordenador Administrativo do PPEUnBIDIOMAS e seu Sub-Coordenador deverão ter, preferencialmente, formação e experiência compatíveis com a função.

Art. 30. O Coordenador Administrativo do PPEUnB-IDIOMAS terá as seguintes atribuições:

I. planejar e promover a divulgação dos cursos e eventos do PPEUnB-IDIOMAS, em âmbito interno e externo;

zelar pelo cumprimento rigoroso do calendário letivo;

realizar, por intermédio da Central de Atendimento, as matrículas dos alunos;

realizar a prestação semestral de contas dos recursos advindos dos cursos ao LET;

fazer gestão visando à assinatura de contratos e convênios para prestação de serviços pelo PPEUnB-IDIOMAS;

zelar pela documentação do PPEUnB-IDIOMAS e supervisionar trabalhos realizados pelos setores sob sua coordenação: Secretaria, Logística, Financeiro, Tecnologia e Gestão de Cursos Corporativos;

assegurar espaço físico para a realização das aulas, bem como prover os professores de apoio logístico necessário para o desenvolvimento de suas atividades; 
administrar os recursos tecnológicos e humanos do PPEUnBIDIOMAS;

providenciar a documentação para a realização de despesas e receitas, tais como pagamento de colaboradores internos e externos, compras de materiais e serviços, recibos de receitas, faturas e outros, com a aprovação da Coordenação Geral do PPEUnB-DIOMAS, e posterior envio às instâncias da Administração Central da FUB para homologação e demais providências cabíveis.

Art. 31. O Sub-Coordenador Administrativo do PPEUnBIDIOMAS terá a atribuição de substituir o Coordenador Administrativo nas suas faltas e impedimentos.

\section{Seção VI - Do Calendário Letivo}

Art. 33. O calendário letivo deverá indicar:

- período de matrícula;

- datas de início e término das atividades;

- dias de aula;

- carga horária do curso;

- datas previstas para provas e exames;

- período de renovação de matrícula.

\section{Seção VII - Da Matrícula}

Art. 34. Os requisitos para matrícula de aluno nos cursos do PPEUnBIDIOMAS são os seguintes:

- preencher ficha de inscrição;

- assinar Termo de Compromisso de prestação de serviços educacionais;

- apresentar cópia de RG e de CPF;

- apresentar cópia de comprovante de residência;

- atender às exigências específicas de cada curso;

- efetuar pagamento do curso, à vista ou parcelado, conforme estipulado no projeto;

- no caso de pessoa menor de idade, o Termo de Compromisso e o formulário de matrícula serão assinados pelo seu responsável.

\section{Seção VIII - Do sistema de avaliação de desempenho dos alunos}

Art. 35.

A avaliação de desempenho do aluno dar-se-á mediante realização de testes ao longo de cada curso ou atividade, conforme determina o projeto do curso e de acordo com acompanhamento da Coordenação Geral.

Art. 36.

Será aprovado no curso o aluno que obtiver:

- mínimo de $75 \%$ (setenta e cinco por cento) de frequência e

- menção mínima para aprovação conforme especificada no projeto do curso. 
Art. 37. Será emitido certificado de extensão após conclusão do curso.

\section{CAPÍtUlo IV - DA PROPOSTA FINANCEIRA}

Art. 38. O PPEUnB-IDIOMAS se auto financiará mediante entrada de recursos provenientes de matrículas efetuadas.

Art. 39. Os recursos obtidos pelo PPEUnB-IDIOMAS serão gerenciados pela Administração Central da Universidade de Brasília, com a disponibilização dos créditos orçamentários no LET/IL, classificado em fonte específica.

Art. 40. A aplicação dos recursos auferidos pelo PPEUnB-IDIOMAS darse-á da seguinte maneira:

- despesas de infraestrutura e logística;

- despesas com pessoal envolvido nos projetos;

- despesas administrativas (incluindo o Serviço de Apoio Administrativo, Técnico e Operacional).

\section{TÍTULO IV - DA COMUNIDADE DO PPEUNB-IDIOMAS}

\section{CAPítulo I - Do CORPo DOCENTE}

Art. 41. O corpo docente do PPEUnB-IDIOMAS será formado por:

I.

II.

III.

Art. 42.

Art. 43.

I.

II.

III.

IV. professores da UnB com formação acadêmica e/ou experiência de ensino na área pertinente;

professores externos à UnB, com formação acadêmica e experiência de ensino na área pertinente, mediante aprovação no processo seletivo simplificado realizado pela coordenação da área envolvida e parecer favorável da Coordenação Geral;

instrutores, mediante aprovação no processo seletivo simplificado realizado pela coordenação da área envolvida e parecer favorável da Coordenação Geral.

No caso de docentes do quadro do IL, fica restrita a sua participação como professores ao teto definido no artigo $7^{\circ}$ da Resolução do Conselho de Administração 004/2012, de 13 de novembro de 2012, que normatiza o pagamento por meio da GECC.

O professor do PPEUnB-IDIOMAS terá as seguintes atribuições:

cumprir rigorosamente o horário de entrada e saída das aulas; comunicar, com antecedência e sempre que possível, quando tiver de faltar à aula, para que se providencie a substituição ou reposição de aula;

cumprir pontualmente os prazos para entrega de relatórios, controle de aula e outros solicitados pelo PPEUnB-IDIOMAS; preparar cada aula com antecedência; 
V.

VI.

Art. 44.

Art. 45.

I.

II.

III.

Art. 46.

I.

II.

III.

IV.

manter-se atualizado tanto em relação às competências linguísticas e comunicativas da língua quanto às diferentes abordagens para ensiná-la;

comparecer pontualmente a todas as reuniões convocadas pelo PPEUnB-IDIOMAS.

\section{Capítulo II - Do corpo discente}

O corpo discente será composto por alunos regularmente matriculados no PPEUnB-IDIOMAS.

São direitos dos alunos, independente da modalidade, curso, nível a que estiver vinculado:

receber a carga horária completa do curso em que está matriculado;

receber tratamento cordial por parte de todos os colaboradores do PPEUnB-IDIOMAS;

receber certificado da Universidade de Brasília, por meio do Decanato de Extensão, quando concluído o curso com aprovação.

São deveres dos alunos:

comparecer regularmente às aulas com o seu material didático; cumprir os horários e prazos estabelecidos;

zelar pela conservação do patrimônio da Universidade de Brasília;

observar e cumprir as normas e orientações no Termo de Compromisso assinado na validação da matrícula.

\section{TÍTULO V - DAS DISPOSIÇÕES GERAIS}

Art. 47. Os professores do PPEUnB-IDIOMAS assinarão proposta simplificada de prestação de serviços educacionais no PPEUnBIDIOMAS, de acordo com a legislação vigente.

Art. 48. As atribuições e competências dos setores mencionados no item VI do Artigo 30 serão definidas por meio de resoluções internas e aprovadas pelo Conselho Deliberativo.

Art. 49. Este Regimento poderá ser modificado sempre que se exigir o aperfeiçoamento da instrução, respeitadas as disposições pertinentes.

Art. 50. Os casos omissos serão solucionados pelo Conselho Deliberativo.

Brasília, de de 2014 


\section{Apêndice C - Questionário de avaliação institucional proposto} pelo Interfoco.

\section{QUESTIONÁRIO DE AVALIAÇÃO DE CURSOS DE EXTENSÃO}

\begin{tabular}{|c|c|}
\hline \multicolumn{2}{|l|}{ NOME } \\
\hline NOME DO PROFESSOR: & PERIODO DO CURSO: \\
\hline & $1 / \mathrm{a}$ \\
\hline
\end{tabular}

Prezado aluno,

Este questionário tem por objetivo a coleta de informações acerca dos diferentes aspectos da atividade de que você acaba de participar, visando ao contínuo aperfeiçoamento dos cursos oferecidos pela Interfoco.

Responda cuidadosamente às questões abaixo e não hesite em fazer os comentários que julgar necessários à melhoria da atividade.

\footnotetext{
1 - QUANTO À DISCIPLINA

1.1. O programa do curso entregue pelo professor foi cumprido.

( ) Sim ( ) Razoavelmente ( ) Não （） Não se aplica ao curso

1.2. O material didático fornecido foi satisfatório quanto à qualidade.

( ) Sim ( ) Razoavelmente ( ) Não ( ) Não se aplica ao curso

1.3. Os recursos audiovisuais, caso tenham sido utilizados, foram satisfatórios quanto à quantidade $\mathrm{e}$ à qualidade.

( ) Sim ( ) Razoavelmente ( ) Não ( ) Não se aplica ao curso
}

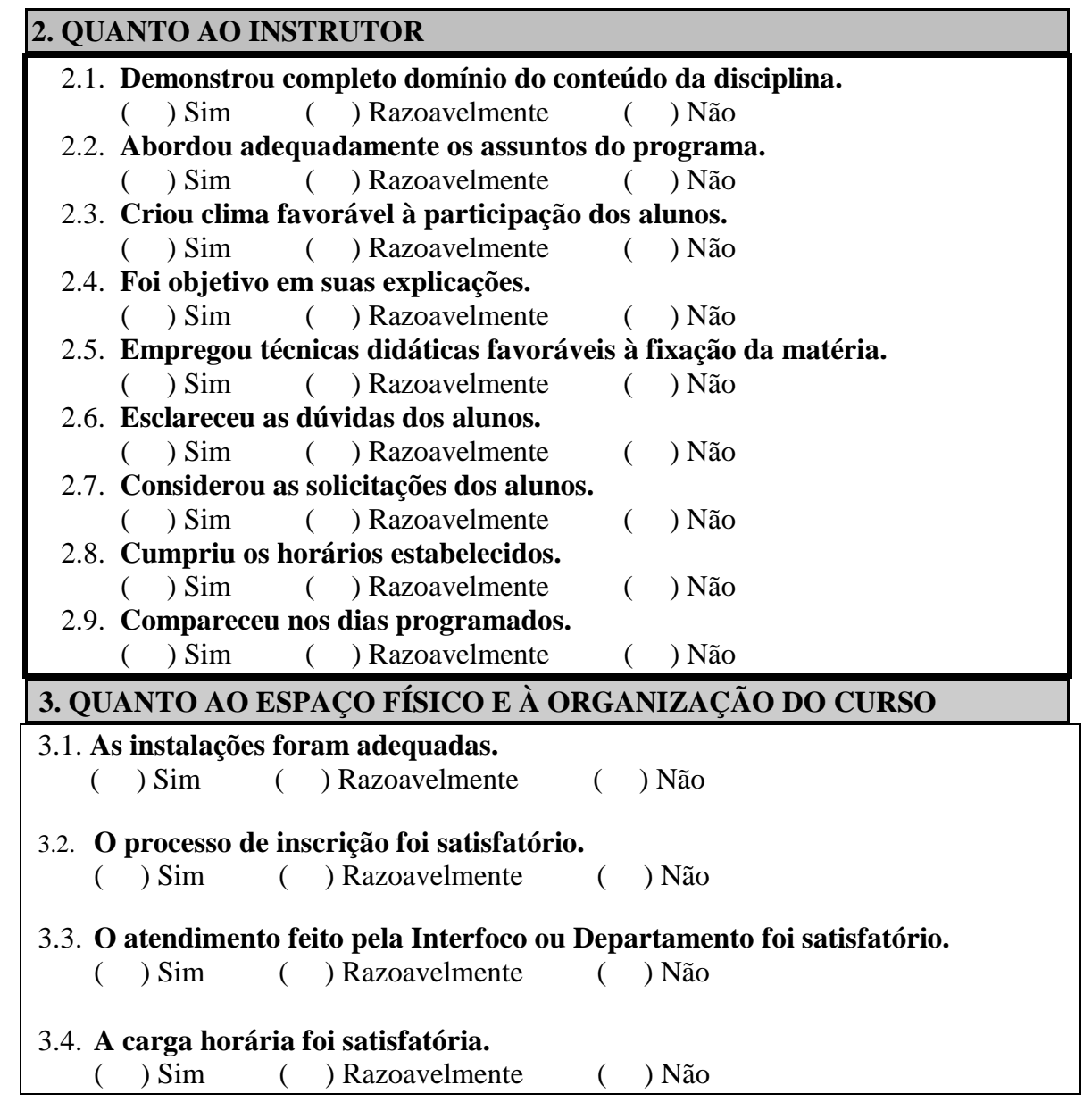




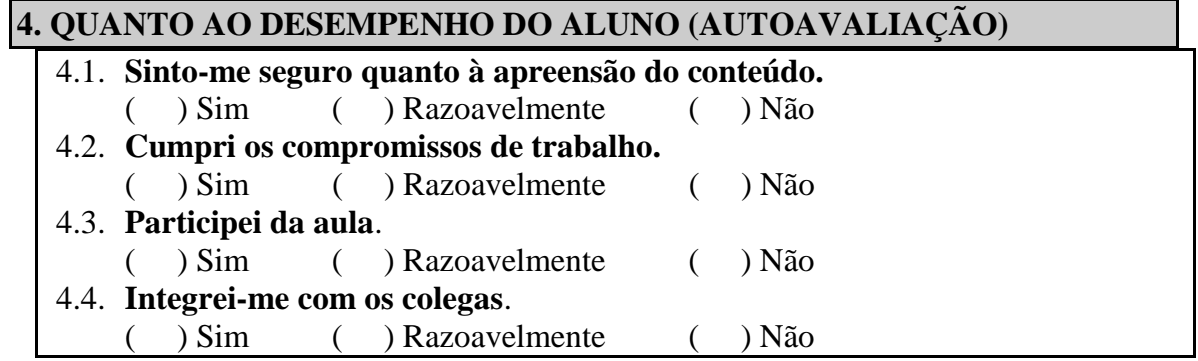

\begin{tabular}{l} 
5. QUANTO À DIVULGAÇÃO \\
\hline 5.1. Você tomou conhecimento do curso por meio de: \\
$\begin{array}{ll}\text { ( ) UnB Hoje, UnB Notícias } & \text { ( ) Correio Braziliense } \\
\text { ( ) Cartaz, folder } & \text { ( ) Jornal de Brasília } \\
\text { ( ) Internet } & \text { ( ) Rádio Cultura FM } \\
\text { ( ) E-mail } & \text { ( ) Amigos } \\
\text { ( ) Outros: } & \end{array}$
\end{tabular}

\section{COMENTÁRIOS E SUGESTÕES FINAIS}

\subsection{Quanto à disciplina.}

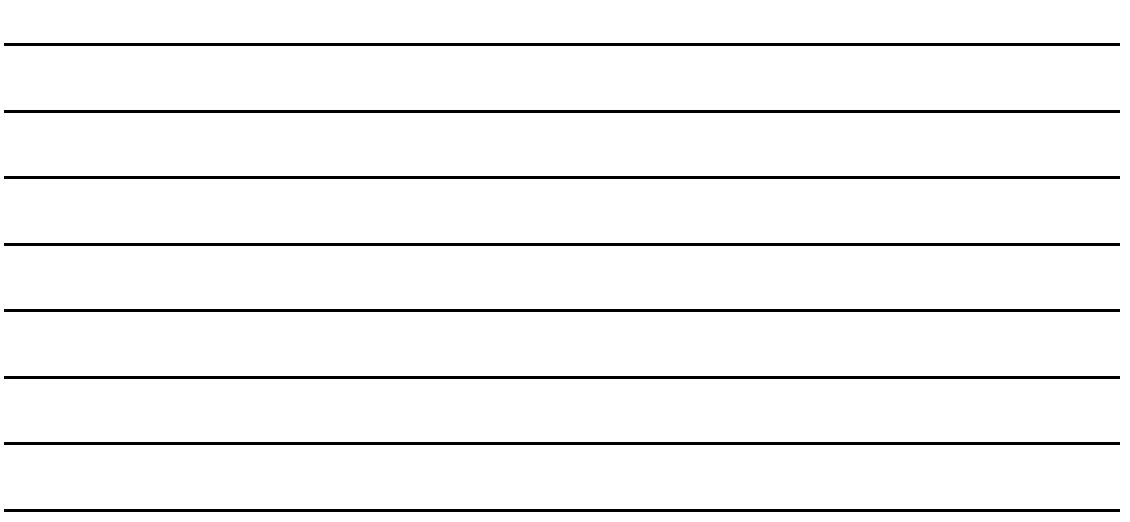

6.2 Quanto ao instrutor.

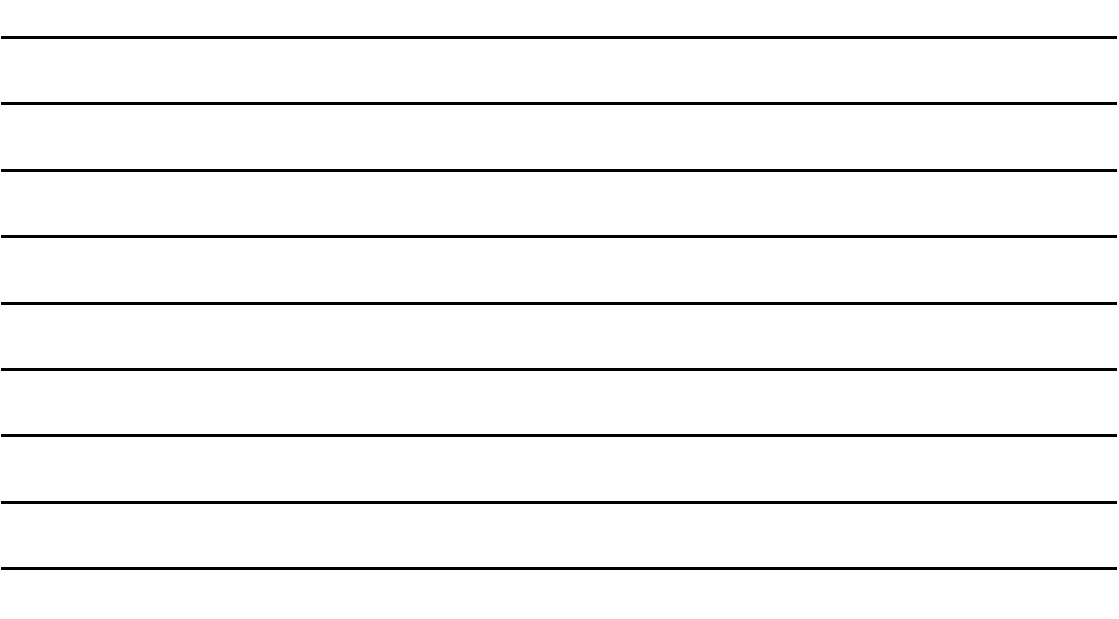

6.3 Quanto ao espaço físico e organização dos cursos.

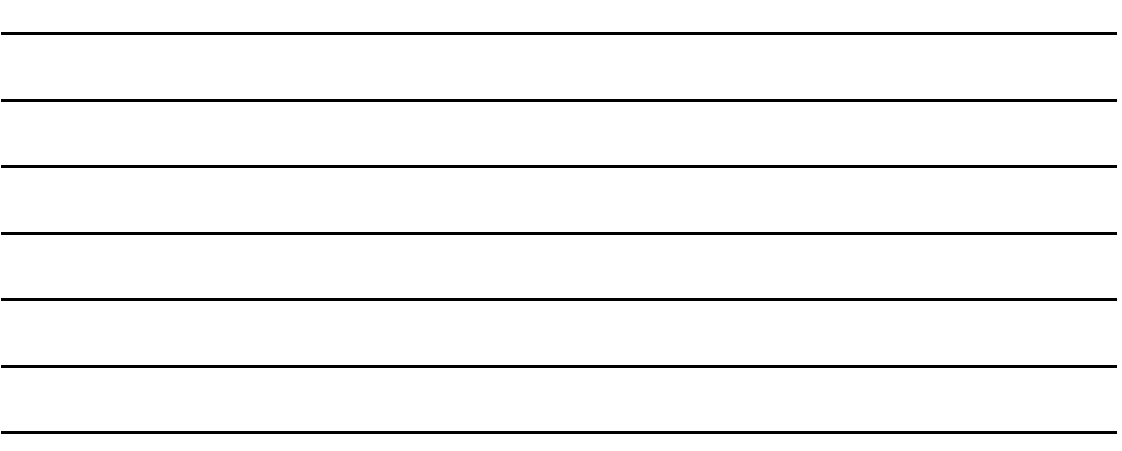




\section{Apêndice D - Tabela dos Indicadores de Qualidade do Curso de Inglês realizada pelo SIG do UnB Idiomas.}

Avaliação dos Indicadores de Qualidade - Cursos Abertos Sequenciais - Idioma Inglês - 2014

Indicadores de Qualidade

Cumprimento do programa do curso

Carga horária do curso

Qualidade do material didático

Qualidade dos recursos áudio visuais

As orientações para realização das atividades foram de fácil compreensão

As orientações para realização das avaliações foram suficientes

Domínio do conteúdo do curso

Abordagem dos assuntos do programa

Favoreceu participação dos alunos

Objetividade nas explicações

Didática na apresentação do conteúdo

Esclarecimento de dúvidas

Consideração das solicitações dos alunos

Cumprimento dos horários estabelecidos

Comparecimento nos dias programados

Instalações adequadas

Processo de inscrição

Cordialidade no atendimento

Rapidez no atendimento

Esclarecimento das dúvidas sobre o curso

Segurança na compreensãoo do conteúdo

Cumprimento das atividades do curso

Participação em sala de aula

Integração com os colegas do curso

Meu grau de conhecimento adquirido com o curso foi satisfatório

Meu grau de satisfação com o curso foi adequado com os objetivos iniciais propostos

$$
\text { RESULTADO FINAL DA AVALIAÇÃO }
$$

\begin{tabular}{|c|c|c|c|c|}
\hline MinObt & MaxObt & Média & DP & ISA\% \\
\hline 1,0 & 5,0 & 4,09 & 1,18 & 81,7 \\
\hline 1,0 & 4,0 & 3,18 & 1,01 & 63,6 \\
\hline 1,0 & 5,0 & 3,90 & 1,19 & 77,9 \\
\hline 1,0 & 5,0 & 3,16 & 1,34 & 63,3 \\
\hline 1,0 & 5,0 & 3,93 & 1,24 & 78,7 \\
\hline 1,0 & 5,0 & 3,99 & 1,21 & 79,7 \\
\hline 1,0 & 5,0 & 4,18 & 1,13 & 83,7 \\
\hline 1,0 & 5,0 & 4,03 & 1,19 & 80,6 \\
\hline 1,0 & 5,0 & 4,05 & 1,24 & 81,0 \\
\hline 1,0 & 5,0 & 3,91 & 1,29 & 78,2 \\
\hline 1,0 & 5,0 & 3,79 & 1,35 & 75,7 \\
\hline 1,0 & 5,0 & 4,01 & 1,25 & 80,3 \\
\hline 1,0 & 5,0 & 4,07 & 1,20 & 81,4 \\
\hline 1,0 & 5,0 & 4,27 & 1,11 & 85,4 \\
\hline 1,0 & 5,0 & 4,41 & 1,01 & 88,3 \\
\hline 1,0 & 5,0 & 2,99 & 1,40 & 59,7 \\
\hline 1,0 & 5,0 & 3,82 & 1,18 & 76,5 \\
\hline 1,0 & 5,0 & 3,74 & 1,20 & 74,8 \\
\hline 1,0 & 5,0 & 3,97 & 1,14 & 79,4 \\
\hline 1,0 & 5,0 & 3,84 & 1,17 & 76,9 \\
\hline 1,0 & 5,0 & 3,86 & 1,07 & 77,2 \\
\hline 1,0 & 5,0 & 4,05 & 1,04 & 81,0 \\
\hline 1,0 & 5,0 & 4,09 & 1,02 & 81,8 \\
\hline 1,0 & 5,0 & 4,01 & 1,04 & 80,1 \\
\hline 1,0 & 5,0 & 3,82 & 1,12 & 76,3 \\
\hline 1,0 & 5,0 & 3,78 & 1,19 & 75,7 \\
\hline $\mathbf{1 , 0}$ & 5,0 & 3,88 & 1,17 & 77,6 \\
\hline
\end{tabular}

MinObt: Nota Mínima Obtida; MaxObt: Nota Máxima Obtida; DP: Desvio Padrão; IS A\%: Índice de Satisfação do Aluno

Fonte: PPE UnB Idiomas

\begin{tabular}{lccc}
\hline & Avaliação por Dimensão & Média & ISA \% \\
\hline Organização Pedagógica & $\mathbf{3 , 7}$ & $\mathbf{7 4 , 1}$ \\
Professor & $\mathbf{4 , 1}$ & $\mathbf{8 1 , 6}$ \\
Organização Administrativa & $\mathbf{3 , 7}$ & $\mathbf{7 3 , 5}$ \\
Desempenho Individual & $\mathbf{4 , 0}$ & $\mathbf{8 0 , 0}$ \\
Avaliação Final do Curso & $\mathbf{3 , 8}$ & $\mathbf{7 6 , 0}$ \\
\hline
\end{tabular}

Índice de Satisfação do Aluno (ISA \%) por Dimensão

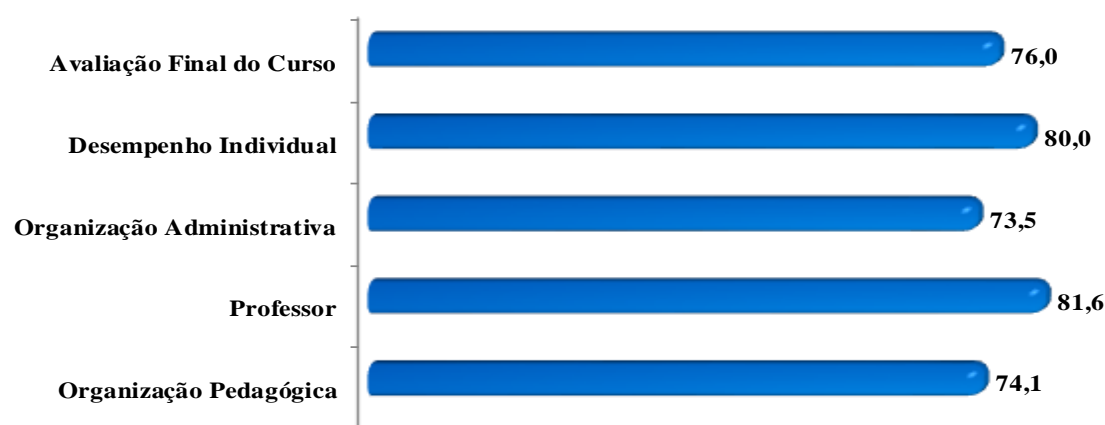

